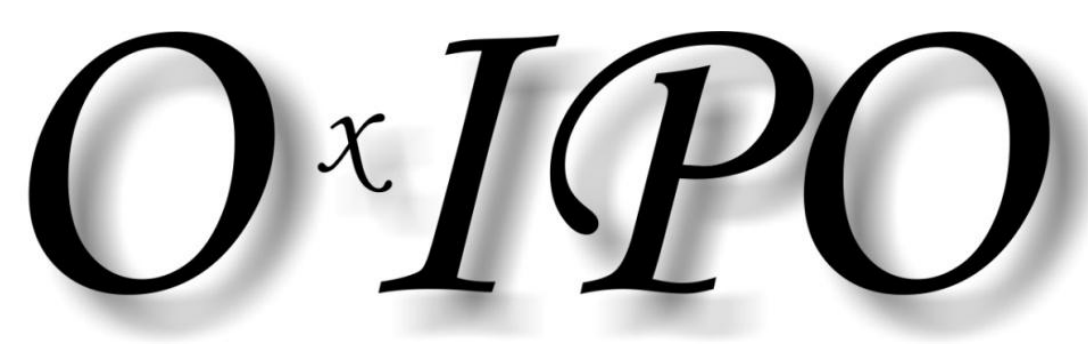

\title{
INTERDISZCIPLINÁRIS E-FOLYÓIRAT
}

DOI 10.35405/OXIPO.2020.3.1

II. évfolyam 2020/3. szám
ISSN 2676-8771

WEB: www.kpluszf.com

\section{K+F STÚDIó Kft.}




\section{IMPRESSZUM}

\section{OxIPO}

Interdiszciplináris e-folyóirat
Alapítva: 2019-ben.
ISSN 2676-8771

A Nemzeti Média- és Hírközlési Hatóság Hivatala a médiaszolgáltatásokról és a tömegkommunikációról szóló 2010. évi CLXXXV. törvény 46.』(4) bekezdése alapján nyilvántartásba vett sajtótermék (határozatról szóló értesítés iktatószáma: CE/5423-5/2019).

Az OxIPO interdiszciplináris e-folyóirat a $\mathrm{K}+\mathrm{F}$ Stúdió Kft. által, társadalmi felelősség-vállalási (CSR) stratégia keretében alapított és kiadott, negyedévente megjelenő Open Access (nyílt hozzáférésû) internetes periodika, melyben két anonim és két nem anonim szakmai lektor bírál minden tanulmányt.

\section{A Kiadó adatai:}

Kiadó: $\mathrm{K}+\mathrm{F}$ Stúdió Kft.

A kiadó srékhelye: 4032 Debrecen, Tarján utca 55.

Mobil: +36-30-4849779

E-mail:info@kpluszf.com

Web: www.kpluszf.com

Kiadásért felelớs sžemély: Mező Katalin (PhD) ügyvezető
A Szerkesztőség adatai:

Levélcím: $\mathrm{K}+\mathrm{F}$ Stúdió Kft., 4032 Debrecen, Tarján utca 55. Mobil: +36-30-4849779

E-mail:info@kpluszf.com Web: www.kpluszf.com Alapitó fösžrerkesztó: Mező Ferenc (PhD)

Együttműködő civil szervezet: Kocka Kör Tehetséggondozó Kulturális Egyesület (www.kockakor.hu)

\section{Szerkesztőség (ABC rendben):} Professzorok az Európai Magyarországért Egyesület (www.peme.hu)

Bárdos Jenő (Professor Eemeritus, dr. habil., DSc, az MTA doktora, Eszterházy Károly Egyetem)

Bodnár Gabriella, (PhD, habil., Soproni Egyetem)

Csibi Sándor (PhD, Marosvásárhelyi Orvosi, Gyógyszerészeti, Tudomány és Technológiai Egyetem, Románia)

Falus Iván (Professor Emeritus, dr. habil., DSc, az MTA doktora, Eszterházy Károly Egyetem)

Farcas Susana (PhD, Babes-Bolyai Egyetem, Románia)

Hanák Zsuzsanna (PhD, habil., Eszterházy Károly Egyetem)

Horák Rita (PhD, Újvidéki Egyetem, Szerbia)

Kálcza Jánosi Kinga (PhD, Babes-Bolyai Egyetem, Románia)

Kelemen Lajos (PhD, Okoskocka Kft.)

Koltay Tibor (PhD, habil., Eszterházy Károly Egyetem)

Koncz István ( $\mathrm{PhD}, \mathrm{CSc}$, Professzorok az Európai Magyarországért Egyesület)

Kozma Gábor (PhD, Gál Ferenc Egyetem)

Lubinszki Mária (PhD, Miskolci Egyetem)

Mező Ferenc (PhD, Eszterházy Károly Egyetem)

Mező Katalin (PhD, Debreceni Egyetem)

Nagyné Dr. Hegedűs Anita (PhD, SZTE)

Nemes Magdolna (PhD, Debreceni Egyetem)

Orbán Réka (PhD, Babes-Bolyai Egyetem, Románia)

Pénzes Dávid (Drs, Káldor Miklós Kollégium)

Pinczésné dr. Palásthy Ildikó (PhD, Debreceni Református Hittudományi Egyetem)

Pšenáková Ildikó (Trnava University in Trnava, Szlovákia)

Pukánszky Béla (Prof. Dr. habil., Dsc, az MTA Doktora, Eszterházy Károly Egyetem)

Pusztai Gabriella (Prof. Dr. habil. Dsc, Debreceni Egyetem)

Simó Ferenc Zoltán (Dr. LL.M, Debreceni Egyetem)

Szabóné Balogh Ágota (PhD, Gál Ferenc Egyetem)

Szebeni Rita (PhD, Eszterházy Károly Egyetem)

Takács Márta (PhD, Újvidéki Egyetem, Magyar Tannyelvű Tanítóképző Kar, Szabadka)

Varga Imre (PhD, Gál Ferenc Egyetem, SZTE, JGYPK)

Vass Vilmos (PhD, habil., Budapesti Metropolitan Egyetem, Selye János Egyetem)

Zvonimir Tomac (PhD, University J.J. Strossmayera of Osijek, Horvátország) 


\section{TARTALOM}

OxIPO II. évf., 2020/3.

\section{LECTORI SALUTEM!}

ELMÉLETI ÉS EMPIRIKUS TANULMÁNYOK

Szerdi Márta, Szőllősi Gergő József, Hegedűs Réka és Barth Anita: SZÍV- ÉS ÉRRENDSZERI MEGBETEGEDÉSEK KÖZÖSSÉGRE IRÁNYULÓ PREVENCIÓJA: FÓKUSZBAN A STROKE

Tuza Alexandra, Szőllősi Gergő József, Szőnyi Krisztina és Barth Anita: AZ EGÉSZSÉGMŰVELTSEEG ÉS A TÁPLÁLKOZÁSI SZOKÁSOK KÖZÖTTI ÖSSZEFÜGGÉS VIZSGÁLATA SERDÜLŐK KÖRÉBEN

Hegedűs Réka Dóra, Barth Anita, Szerdi Márta és Szőllősi Gergő József:

FIATALOK SZEXUÁLIS MAGATARTÁSÁNAK VIZSGÁLATA

GIMNÁZIUMBAN TANULÓK KÖRÉBEN - EGY VIZSGÁLAT KEZDETI EREDMÉNYEI

Tudlik Csilla:

A PÁLYAÉRDEKLŐDÉS KAPCSOLATA A PÁLYAVÁLASZTÁSI BIZONYTALANSÁGGAL ÉS A KARRIERDÖNTÉSI ÉN-HATÉKONYSÁGGAL

Varga-Csikász Csenge:

A DRÁMAPEDAGÓGIA HATÁSA A TANÁRI KOMPETENCIÁK ALAKULÁSÁRA

MÓDSZERTANI TANULMÁNYOK

Angeli Csenge:

MULTIPROFESSZIONÁLIS REHABILITÁCIÓS TEAM

KOMMUNIKÁCIÓJÁNAK VIZSGÁLATI LEHETŐSÉGEI

Bodnár Noémi:

HOGYAN KÉSZÜL EGY JELNYELVI (SZLENG)SZÓTÁR?

Mező Lilla Dóra: ROBOTOK, HADVISELÉS, TANULÁS ÉS A VILÁGÜR MEGHÓDÍTÁSA

- AVAGY: AZ V. NEMZETKÖZI INTERDISZCIPLINÁRIS KONFERENCIA MŰHELYTITKAI

RECENZIÓ

Almási Brigitta:

RECENZIÓ A „GYERMEKEK, TANÁROK, ISKOLÁK - EGYKORON ÉS MA.

TANULMÁNYOK A 90 ÉVES MÉSZÁROS ISTVÁN TISZTELETÉRE” CÍMÚ KÖNYVRŐL 


\section{LECTORI SALUTEM!}

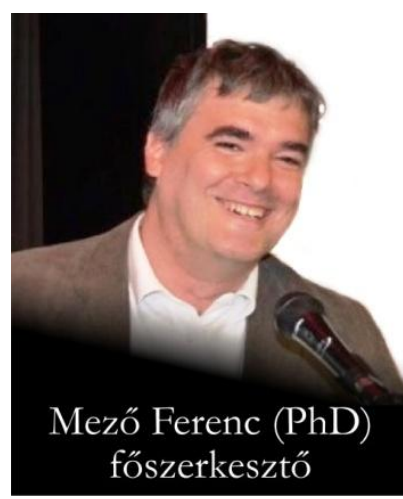

\section{Tištelt Olvasó!*}

Üdvözöljük az OxIPO interdiszciplináris e-folyóirat 2020/3 számának Olvasói között! Jelen lapszám a humán információfeldolgozás következő aspektusait tárja elénk:

Szerdi Márta, Szőllősi Gergő József, Hegedűs Réka és Barth Anita a betegoktatás jelentőségét a szív- és érrendszeri megbetegedések vonatkozásában hangsúlyozzák tanulmányukban. A betegoktatás az OxIPO sémán alapuló elemzéssel is megközelíthető - például: a stroke-kal

*Kedves Olvasó! Ha az OxIPO mozaikszó az Ön számára még nem ismerős, akkor javasoljuk, hogy a lappal való ismerkedést jelen számon túl az alábbi témafelvető tanulmány megismerésével kezdje:

Mező Ferenc és Mező Katalin (2019): Az OxIPOmodell - az interdiszciplináris kutatások egy lehetséges értelmezési kerete. $O x I P O$ - interdiszciplináris tudományos folyóirat, 2019/1, 9-21. doi: 10.35405/OXIPO.2019.1.9 kapcsolatban adott információ, mint input, milyen egészségvédő magatartást (=output) von maga után. Hasonló a helyzet Tuza Alexandra, Szőllősi Gergő József, Szőnyi Krisztina és Barth Anita egészségműveltségre és táplálkozási szokásokra fókuszáló tanulmányával, valamint Hegedűs Réka Dóra, Barth Anita, Szerdi Márta és Szőllősi Gergő József fiatalok szexuális magatartásának megismerésével foglalkozó művével.

Az egészségügyi témájú írások után Tudlik Csilla a pályaorientáció világába kalauzol bennünket. OxIPO vonatkozás: a pályaérdeklődést, pályaválasztási döntést is a személyt érő bemenő információk (inputok) feldolgozása révén kialakuló válasznak (outputnak) tekinthetjük, mely folyamat alakulhat spontán, vagy többékevésbé szervezett módon is.

Ezt követően három olyan mű következik, amelyet a kommunikáció köt össze egymással: Varga-Csikász Csenge tanulmánya a drámapedagógia szerepét emeli ki a tanári kompetenciák szempontjából. Angeli Csenge a multiprofesszionális rehabilitációs csoportok kommunikációs sajátosságait tárja fel. Bodnár Noémi pedig a jelnyelvi szleng szótár készítésének nehézségeit, módszereit mutatja be.

Jelen lapszámban Mező Lilla Dórától olvasható még egy beszámoló az V. Nemzetközi Interdiszciplináris Konferenciáról (melynek OxIPO vonatkozása is volt).

Végül a Recenzió rovatban Almási Brigitta hívja fel figyelmünket a „Gyermekek, 
tanárok, iskolák - egykoron és ma. Tanulmányok a 90 éves Mészáros István tiszteletére" című, Németh András és Pukánszky Béla által szerkesztett műre.
Kellemes és hasznos barangolást kiván a bumán információfeldolgozás világában:

Męő" Ferenc

föszerkesztó 


\section{ELMÉLETI ÉS EMPIRIKUS TANULMÁNYOK}




\title{
SZÍV- ÉS ÉRRENDSZERI MEGBETEGEDÉSEK KÖZÖSSÉGRE IRÁNYULÓ PREVENCIÓJA: FÓKUSZBAN A STROKE
}

\author{
Szerzők: \\ Szerdi Márta \\ Debreceni Egyetem \\ Szőllősi Gergő József \\ Debreceni Egyetem \\ Hegedűs Réka \\ Debreceni Egyetem \\ Barth Anita \\ Debreceni Egyetem
}

Első szerző e-mail címe:

marti199971@gmail.com

\author{
Lektorok: \\ Ujváriné Dr. Siket Adrienn \\ Debreceni Egyetem \\ Dr. Sárváry Attila \\ Debreceni Egyetem \\ ...és további két anonim lektor
}

\begin{abstract}
Absztrakt
Az elvégzett kutatás arra irányult, hogy felmérjük az egészségügyi centrumoktól távol eső, Szabolcs-Szatmár-Bereg megye Újdombrád község lakóinak betegség specifikus tudását, jelen esetben a stroke-kal kapcsolatban. Ezen túlmenően megvizsgáltuk, menynyire hatékonyak a prevenciós előadások, a lakosság mennyire tartja ezeket hasznosnak, és hogy tartanak-e igényt további, más betegségekről szóló előadásoknak is.
\end{abstract}

Kulcsszavak: stroke, Újdombrád, egészségfejlesztés, prevenció

Diszciplina: egészségtudomány

\begin{abstract}
COMMUNITY-BASED PREVENTION OF CARDIOVASCULAR DISEASE: FOCUS ON STROKE

The aim of the study was to assess the disease-specific knowledge of the inhabitants of the municipality of Újdombrád in Szabolcs-Szatmár-Bereg County in this case in
\end{abstract}


relation to strokes. In addition, we examined how effective the health education was, and how useful the population finds them, lastly if they want more additional lectures about other diseases.

Keywords: stroke, Újdombrád, health promotion, prevention

Disciplines: health sciences

Szerdi Márta, Szőllősi Gergő József, Hegedűs Réka és Barth Anita (2020): Szív- és érrendszeri megbetegedések közösségre irányuló prevenciója: fókuszban a stroke. OxIPO - interdiszciplináris tudományos folyóirat, 2020/3, 9-18. doi: 10.35405/OXIPO.2020.3.9

Jelen kutatást a szív- és érrendszeri megbetegedések prevenciójával kapcsolatosan végeztük, melynek fő célja a strokekal kapcsolatos ismeretek feltérképezése egy Szabolcs-Szatmár-Bereg megyei község lakóinak körében. Fontos e területen is a primer prevenció, mivel világszerte a vezető halálokok közé tartoznak a kardiovaszkuláris és cerebrovaszkuláris megbetegedések.

Az Amerikai Szív Szövetség által kiadott statisztikákban 2000 és 2010 között a stroke miatti halálozás relatív aránya 35,8\%-kal csökkent, viszont évente körülbelül 795000 ember szenved el új (610 000 ember) vagy ismétlődő (185000 ember) szélütést. A legelszomorítóbb adat, amely a laikusokat is megdöbbenti, hogy az Egyesült Államokban átlagosan 40 másodpercenként ér valakit stroke, míg 4 percenként meg is hal benne valaki (Go és tsai, 2014).
Az OECD tanulmány több országban végzett elemzést az ott élők születéskor várható átlagos élettartamáról, mely a mortalitás és morbiditás mellett megfelelő mutatószáma az egyének egészségi állapotának. Az eredmények alapján a várható élettartam az OECD által vizsgált országokban megnőtt az elmúlt néhány évtizedben, azonban a növekedés az utóbbi években lelassult. Három csoportot határoztak meg, melyből hazánk a legutolsó csoportba tartozik, ahol a születéskor várható átlagos élettartam 76 év alatt volt. Továbbá ez a tanulmány kitért a keringési rendszeri betegségek miatt bekövetkező halálozásokra is. Az OECD országokban még mindig a vezető halálokok közé tartoznak, a stroke és a szívinfarktus az a két eset, mely körülbelül minden harmadik haláleset kiváltója. Ennek ellenére a halálozási statisztikák lassan ugyan, de javuló tendenciát mutatnak a betegségcsoportra 
nézve és sok országban a születéskor várható átlagos élettartam is emelkedett (OECD, 2019).

Az ENSZ 2011-es értekezletén is kiemelt szerepet kaptak a szív- és érrendszeri megbetegedések és a stroke. Mivel e betegségek a haláloki listákon vezető helyet foglalnak el, célul tűzték ki, hogy 2025-re 25\%-kal csökkentik e betegségek miatti korai halálozást. A cél elérése érdekében különböző célkitűzéseket határoztak meg, mégpedig azt, hogy a dohányzás gyakoriságát 30\%-kal csökkentik, 25\%-os relatív csökkenést szeretnének elérni a magasvérnyomás betegség prevalenciájában, valamint csökkentenék az elhízást és a diabetes mellitus előfordulását.

A célok kitűzése mellett stratégiai javaslatokat is tettek a tagországoknak. A hipertónia csökkentését a különböző termékek sótartalmának redukálásával, valamint a sófogyasztás káros hatásainak ismertetésével kívánták elérni.

Mindemellett javasolták az egészséges étrend és a fizikai aktivitás hatásainak propagálását és hangsúlyozták a rendszeres vérnyomásmérést az egészséges egyének körében.

A diabetes mellitus és az elhízás visszaszorítását az élelmiszerek transzzsírsavtartalmának csökkentése mellett a magas transzzsírsavtartalmú táplálék árának növelésével akarták megállítani, emellett fel kívánták hívni a figyelmet a rendszeres fizikai aktivitás fontosságára (Kékes, 2018).

\section{A BETEGOKTATÁS JELENTOÖ- SÉGE A PREVENCIÓBAN}

Ahhoz, hogy az emberek megfelelő tájékoztatást és ismereteket kapjanak a megelőzésről, az egészséges életmódról, a rendeleteken, lakossági szűréseken túl fontos, hogy a primer prevenció részeként a lakosság különféle prevenciós előadások formájában, akár online módon is tájékozódhasson, információt szerezzen. Ilyen kezdeményezés a Szív Világnapja, melyet 2000 óta minden év szeptemberében megrendeznek világszerte. Ezen rendezvény- és előadássorozat a kezdetektől Magyarországon is megrendezésre kerül minden évben. Budapesten 2019-ben a résztvevőknek megadatott az a lehetőség, hogy részt vegyenek ingyenes vércukorszint-, koleszterin-, érszúkület-, vérnyomás- és testzsír mérésen, valamint SCORE meghatározáson, EKG vizsgálaton is. Ezek mellett előadásokat is tartottak, melyek az életmódváltást, az egészségesebb életmódot járták körbe. A Szív Világnapi rendezvényt fővárosunk után Nyíregyházán is minden évben megtartják, ahol, hasonlóan Budapesthez, előadásokkal és szűrésekkel népszerűsítik a kardiovaszkuláris prevenció fontosságát (Net1, Net2).

Egy Olaszországi hipertónia központban végeztek egy tanulmányt, melyben 2 csoportra osztották a résztvevőket, és a folyamatos tájékoztatás hasznosságát vizsgálták, vagyis az egyik csoport csak egy alap oktatást kapott, míg a másik rendszeres online oktatásban vett részt. 
Eredményesnek bizonyult ez a módszer (Cicolini és tsai, 2013).

Ezen rendezvények azonban leginkább a felnőtteket célozzák, de a prevencióban fontos, hogy már fiatalabb korban is ismerjék és tudják, hogy milyen következménye is lehet egy-egy káros szenvedélynek vagy egészségtelen életmódnak. Erre ad megoldást a Budapesti Orvostanhallgatók Egyesülete, ahol számos előadást szerveznek és tartanak egyetemisták középiskolás hallgatóknak, többek között a kardiovaszkuláris prevencióról is. Ezek mellett a szűrővizsgálatokra és az otthon is elvégezhető önvizsgálatra hívják fel a figyelmet (Net3).

Egyéni egészségterv készítésére létrehozott online felületen fény derülhet az egyént veszélyeztető különféle kockázati tényezőkre. Ez a weboldal az Állami Egészségügyi Ellátó Központ által fejlesztett Magyar Egészségtervező Alkalmazás, ami mindenki számára egyszerűen és ingyenesen kitölthető egészségfelmérő kérdőív. A beérkezett válaszok összesítése után kiértékeli a program, hogy az adott egyén milyen rizikótényezőkkel él együtt, majd ezek után sem engedi el a felhasználó kezét az applikáció, ugyanis javaslatokat tesz arra nézve, hogy hogyan is csökkentheti és szüntetheti meg a fennálló kockázatokat. Ezt az alkalmazást egészségügyi szakemberek bevonásával alkalmazzák, ahol a páciens egy egészségtanácsadóval együtt tölti ki és értékeli a kérdőívet. Ez a fajta tanácsadás közvetlenebb, személye- sebb, több lehetőséget ad az egyénnek, hogy kérdezzen (Net4).

Elengedhetetlen tehát, hogy rendszeressé és a lakosság minden rétegének elérhetôvé váljanak olyan oktatóanyagok, előadások, melyek felvilágosítást nyújtanak egyes betegségek tüneteiről, szövődményeiről, a primer prevenció jegyében azok megelőzéséről is.

\section{MÓDSZER}

\section{Minta}

Újdombrád lakossága, a 2015-ös adatok alapján 736 fö, melynek 51,22\%-a 18-54 év közötti, 25\%-a pedig 55 év feletti lakos. Tehát a lakosság negyede abban a korban van, ahol a legmagasabb a veszélyeztetettség a kardiovaszkuláris betegségekkel kapcsolatban, valamint több mint az emberek fele olyan életkorú, amikor a legtöbbet lehet tenni a szív- és érrendszeri megbetegedések ellen. Az egészségdélutánt plakátokkal népszerűsítettük a falu különböző pontjain elhelyezett hirdetőtáblákon, valamint az orvosi rendelőben. Az egészségdélutánon 33 lakos jelent meg. Százalékosan a teljes lakosság 4,48\%-a, mely jó aránynak számít a lakosságszámot tekintve.

\section{Eszközök}

Saját szerkesztésű kérdőívünk önkéntes és anonim volt. Kérdőívünk az alábbi kérdéscsoportokat érintette: szociodemográfiai adatok, a témával kapcsolatos 
információszerzési szokások, tudásszint felmérő teszt. A 10 kérdésből álló tudásszint felmérő teszt egyszerű és többszörös választásos kérdéseket egyaránt tartalma- zott. Válaszonként egy jó pontot lehetett szerezni, így a maximálisan elérhető pontszám 10 pont lett (1. táblázat).

\section{1. táblázat: Tudásszint felmérö teszt kérdései (forrás: a Szuerzők)}

\begin{tabular}{|rl|c|}
\hline \multicolumn{2}{|c|}{ Tudásszint felmérő teszt kérdései } & Kérdés jellege \\
\hline 1. & Mi az a stroke? & Egyszeres választás \\
\hline 2. & Mi az a TIA? & Egyszeres választás \\
\hline 3. & A felsoroltak közül melyik a stroke egyik típusa? & Egyszeres választás \\
\hline 4. & $\begin{array}{l}\text { Melyik nem képviselői a legveszélyeztetettebbek a stroke } \\
\text { szempontjából? }\end{array}$ & Egyszeres választás \\
\hline 5. & $\begin{array}{l}\text { Melyik a stroke kialakulásában szerepet játszó BEFOLYÁ- } \\
\text { SOLHATÓ kockázati tényező az alábbiak közül? }\end{array}$ & Egyszeres választás \\
\hline 6. & $\begin{array}{l}\text { Melyik a stroke kialakulásában szerepet játszó NEM BEFO- } \\
\text { LYÁSOLHATÓ kockázati tényező az alábbiak közül? }\end{array}$ & Egyszeres választás \\
\hline 7. & Örökölhető-e a stroke? & Egyszeres választás \\
\hline 8. & Mely esetben kell stroke-ra gyanakodni? & Egyszeres választás \\
\hline 9. & Melyek a stroke fenyegető tünetei? & Többszörös választás \\
\hline 10. & $\begin{array}{l}\text { Az alábbiak közül melyik állítás a döntô jelentőségú a stroke } \\
\text { kezelésében? }\end{array}$ & Egyszeres választás \\
\hline
\end{tabular}

A résztvevők a tudásszint felmérő tesztet az egészségdélután elején és végén is kitöltötték. Az előadás végén kitöltött tudásszint felmérō teszt ugyanazon kérdéseket tartalmazta, mint az első kérdőív, de más sorrendben, ezzel elkerülve, hogy valaki emlékezetből válaszoljon a kérdésekre. Az előadás végén a tudásszint felmérő teszten kívül egy elégedettségi kérdőívet is kitöltöttek a résztvevők.

\section{Eljárás}

Egy általunk szervezett egészségdélután keretén belül tartottuk második alkalommal prevenciós előadásunkat a stroke témakörében, a Szabolcs-Szatmár-Bereg megyei Újdombrád község lakóinak. Az előadás előtt és az előadás után is felmérésre került a résztvevők ismerete a témakörrel kapcsolatosan. 
Az adatok feldolgozása és elemzése a Stata Statistical Software: Release 13. for statisztikai szoftvercsomag alkalmazásával történt. Az adatok elemzése során első lépésben a folytonos változók normalitását vizsgáltuk meg (Sapphiro-Wilk próbával). Az első tudásszint felmérő teszt követte a normális eloszlást, a második azonban nem, ezért az előtte-utána típusú elemzések nem-paraméteres eljárásokkal történtek meg. Az adatpárok összehasonlítása Wilcoxon-féle előjeles rangpróba tesztekkel történt meg. Az adatok bemutatása a kérdőív kérdéseire adott válaszok százalékos megoszlásának segítségével történt meg, ahol az adott válaszhoz tartozó részarányok kerültek bemutatásra.

\section{EREDMÉNYEK}

A résztvevök szocio-demográfiai adatai

A megjelentek körében a nemek szerinti eloszlást tekintve többségben voltak a nők (nő: 78,79\% (N=26); férfi: 21,21\%-ot $(\mathrm{N}=7))$. Az életkor szerinti megoszlás bemutatásánál a KSH által alkalmazott korcsoportok szerinti felosztást alkalmaztuk. Ez alapján elmondható, hogy a résztvevők 6,06\%-a (N=2) 0-18 éves, 78,79\%a $(\mathrm{N}=26)$ 19-54 éves, $15,15 \%-\mathrm{a} \quad(\mathrm{N}=5)$ pedig 55 év feletti. A résztvevők többsége középfokú iskolai végzettséggel rendelkezik (felsőfokú: 6,06\% ( $\mathrm{N}=2)$; középfokú: $72,72 \%(\mathrm{~N}=24)$; alapfokú: 21,21\% (N=7)) (lásd 2. táblázat).

2. táblázat: Szocio-demográfiai adatok $(N=33)$. Forrás: a Szerző́k

\begin{tabular}{ll|r}
\hline \multicolumn{1}{c|}{ Változók } & \multicolumn{1}{c}{ Résztvevők } \\
\hline Átlagéletkor & Évek & \multicolumn{1}{c}{$41,67 \pm 14,32$} \\
\multirow{2}{*}{ Korcsoportok } & $0-18$ & $6,06 \%(\mathrm{~N}=2)$ \\
& $19-54$ & $78,79 \%(\mathrm{~N}=26)$ \\
\multirow{2}{*}{ Nem } & $55+$ & $15,15 \%(\mathrm{~N}=5)$ \\
& Nö & $78,79 \%(\mathrm{~N}=26)$ \\
\multirow{2}{*}{ Iskolai végzettség } & Férfi & $21,21 \%(\mathrm{~N}=7)$ \\
& Alapfokú & $21,21 \%(\mathrm{~N}=7)$ \\
& Középfokú & $72,72 \%(\mathrm{~N}=24)$ \\
& Felsőfokú & $6,06 \%(\mathrm{~N}=2)$ \\
\hline
\end{tabular}

A rész̨tvevók információkeresési sqokásai

Az 1. ábráról leolvasható, hogy a legtöbben az internetről $(48,48 \%, \mathrm{n}=16)$ szerzik információikat a betegséggel kapcsolatosan. Magas azon emberek száma is, akik orvosuktól $(24,24 \%, n=8)$ kérnek tájékoz- 
tatást, valamint azok is kiemelkednek, akik egyáltalán nem néztek utána a szélütésnek (36,36\%, n=12). Ezzel szemben elenyésző azon emberek száma, akik családjuktól
$(9,09 \%, \mathrm{n}=3)$, barátoktól $(6,06 \%, \mathrm{n}=2)$, körzeti ápolótól $(9,09 \%, \mathrm{n}=3)$, valamint egyéb helyről $(3,03 \%, n=1)$ szerzi be információit.

1. ábra: Stroke-kal kapcsolatos információszerzési források $(N=33)$. Forrás: a Szuerzőo

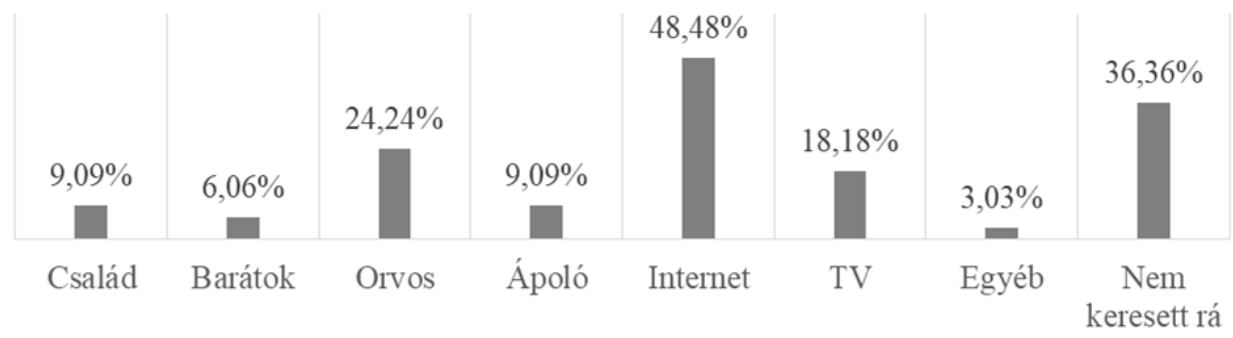

A rész̧tvevoók ismeretei

a stroke-kal kapcsolatban

A résztvevők előadás előtti tudásszint felmérő tesztjeinek az összesített pontszámainak mediánja 5,00 (iqr=2,00), míg ez a szám az előadás után kitöltött tesztek esetében 9,00 (iqr=2,00). A tudásszint változásában szignifikáns összefüggést tapasztaltunk ( $\mathrm{p}<0,001$; lásd: 2 . ábra).

2. ábra: az elöadás elötti és utáni tudáspontszám alakulása (N=33). Forrás: a Szerzók

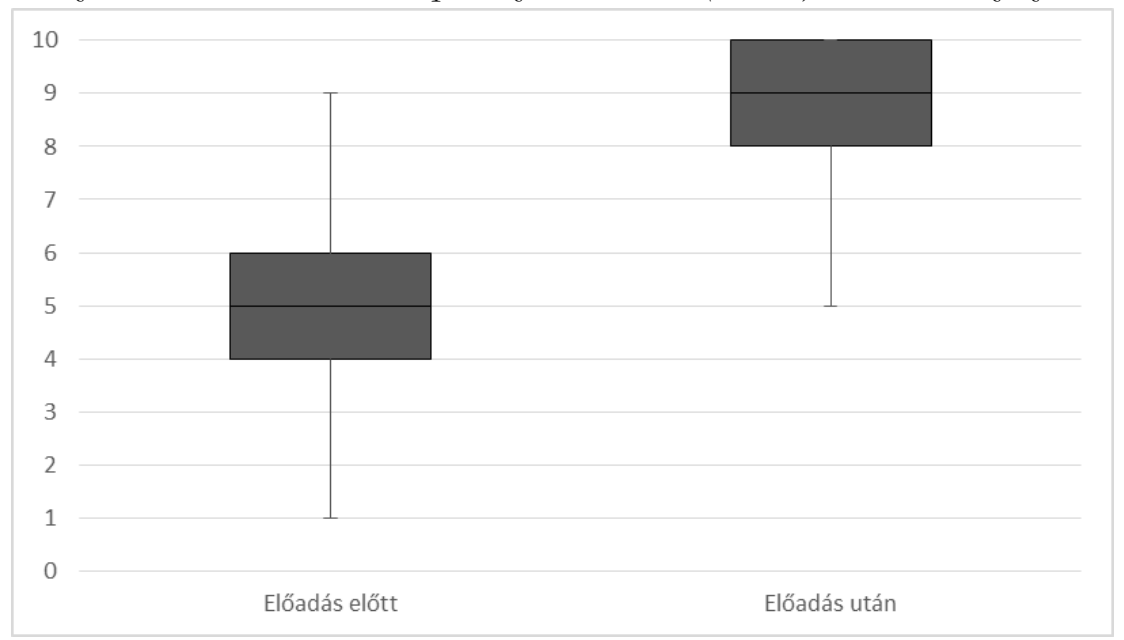


A szocio-demográfiai tényezők közül az életkor nem bizonyult befolyásoló tényezőnek (Coeff: -0,004; $\mathrm{p}=0,878$ ). A nemek vonatkozásában elmondható, hogy mind a nők mind pedig a férfiak szignifikánsan magasabb pontszámot értek el az előadás utáni tudásszint felmérő teszten $(\mathrm{p}<0,001)$. Az iskolai végzettség tekintetében elmondható, hogy csupán a középfokú iskolai végzettséggel rendelkező személyek értek el szignifikánsan magasabb pontszámot $(\mathrm{p}<0,001 ; 2$. táblázat).

2. táblázat: A tudásszint változása a szocio-demográfiai tényezőo vonatkozásában $(N=33)$. Forrás: a Szerzoōk

\begin{tabular}{ll|ccc}
\hline Változó & & $\begin{array}{c}\text { Előadás elötti } \\
\text { tudáspontszám } \\
\text { medián (iqr) }\end{array}$ & $\begin{array}{c}\text { Elóadás utáni } \\
\text { tudáspontszám } \\
\text { medián (iqr) }\end{array}$ & p-érték \\
\hline Nem & Férfi & $4,00(6,00)$ & $9,00(1,00)$ & $\mathrm{p}<0,001$ \\
& Nő & $5,00(2,00)$ & $9,00(2,00)$ & $\mathrm{p}<0,001$ \\
\hline Iskolai & Alapfokú & $6,00(4,00)$ & $8,00(3,00)$ & $\mathrm{p}=0,146$ \\
végzettség & Középfokú & $5,00(2,00)$ & $9,00(1,00)$ & $\mathrm{p}<0,001$ \\
& Felsőfokú & $5,00(0,00)$ & $8,50(0,50)$ & $\mathrm{p}=0,179$ \\
\hline
\end{tabular}

A rész̨uvevók véleménye az egészségdélutánról

Az értékelő kérdőív adatainak elemzése alapján elmondható, hogy résztvevők egy 10 fokú Likert-skálán átlagosan 9,91 pontra értékelték annak hasznosságát. Valamennyi résztvevő igényt tartana további prevenciós előadások részvételére.

\section{MEGVITATÁS}

Az életkori eloszlást figyelembe véve magyarázható az, hogy a kérdőívet kitöltôk nagy része az interneten keres információkat a betegségekkel, annak megelőzésével kapcsolatosan. Laikusként azon- ban nem mindig egyszerū kiszűrni azt, hogy melyik honlap közöl hiteles információkat az olvasóval, így a prevenciós előadások tartása segítheti a világhálón is böngészőket abban, hogy felismerhessék a hamis híreket.

Abból, hogy a megjelentek nagy része önbevallása alapján már korábban tájékozódott a betegségről, az következne, hogy a tudásszint felmérő teszten magas pontszámok születnek. Ez azonban nem így alakult, hiszen az előadás előtti tudásszint felmérô teszten a megszerezhető pontok közel felét érték csupán el. Ez is alátámasztja azt a feltételezést, hogy ugyan in- 
formálódnak az egyének a betegségekről, azonban ezek az információk nem biztos, hogy hitelesek. Az információszerzési szokásokból kitűnik az is, hogy sok olyan ember van, aki egyáltalán nem néz utána a betegségnek, vagy az azzal kapcsolatos prevenciós stratégiáknak sem. Ezen hozzáállás is épp úgy veszélyes lehet, mint a hitelt nem érdemlő forrásokból való tájékozódás. Ugyanis, ha a stroke-kal kapcsolatban valaki azt az alap információt sem tudja, hogy hogyan ismerhető fel az, ha valaki szélütést szenved el, a károsult személy nem jut időben kórházba, mellyel az egészségben eltöltött életéveinek száma lecsökkenhet.

A tudásszint felmérő teszt eredményei alapján elmondható, hogy a résztvevők keveset tudtak a betegséggel kapcsolatosan. Ezen tudatlanság vezethet ahhoz, hogy a kardiovaszkuláris és cerebrovaszkuláris kórképek miatti halálozás még mindig élen jár a haláloki listán. A prevenciós előadások tartása ezt a tudatlanságból fakadó megbetegedéseket és felesleges halálokat előzhetné meg, mellyel csökkenthető lenne a betegségteher, amit az egyének kiesése a munkából és a kórházakba való bekerülése ró az egészségügyre, családokra, magára az egyénre, valamint közvetve az egész társadalomra. Ugyanakkor a prevenciós előadások végén mért tudásszintbeli javulás mutatja a prevenciós előadások hatékonyságát. A résztvevők többsége figyelmesen hallgatta végig az előadást, és összefüggéseiben is értelmezték az elhangzottakat, mely tu- dással már sikeresen ki tudták tölteni a kérdőívet.

Az elégedettségi kérdőív eredményéből következik, hogy az emberek szívesen vettek részt a prevenciós előadáson, hasznosnak gondolták azt. A személyes beszélgetésekből is tükröződött, hogy az emberek további előadásokat is szeretnének meghallgatni különféle egészséggel kapcsolatos témákban.

\section{KORLÁTOZÁSOK}

Az előadáson kis létszámban jelentek meg, így a minta nem reprezentatív. A nem, életkor, iskolai végzettség szerinti eloszlás sem egyenlő, mely így az esetleges tudásszintbeli változás összehasonlítása során sem mutat valós képet.

\section{KONKLÚZIÓK}

Összességében elmondható, hogy a lakosság számára tartott egészséggel kapcsolatos, prevenciós jellegű előadások hasznosak. Ezt tükrözik egyrészt a tudásszint felmérő teszten kapott eredmények valamit az értékelő kérdőív eredményei is. A résztvevők egy-egy ilyen előadás alkalmával hasznos, a mindennapokban is használható információt nyernek különféle betegségcsoportokkal kapcsolatosan. Mindemellett hozzásegíti őket az interneten található információk hitelességének megállapításához is. A község lakóinak számára tartott előadások számának növelése éppen ezért indokolt. A létszám nö- 
velése mellett fontos lenne azon egyének megnyerése is, jelen esetben az idősebbek és a férfiak, akik jelen egészségdélutánon alacsony számban vettek részt, hisz vannak olyan betegségek, amelyek kifejezetten rájuk jelentenek veszélyt.

\section{IRODALOM}

Go, A. S. et al. (2014): Executive Summary: Heart Disease and Stroke Statistics-2014 Update. Circulation, 129, 399-410. doi: 10.1161/01.cir.0000442015.53336.12 OECD (2019), Health at a Glance 2019: OECD Indicators, Paris: OECD Publishing. doi: 10.1787/4dd50c09-en

Kékes E. (2018): A korai kardiovaszkuláris mortalitás csökkentésének ENSZ terve 2025-ig, és a program sikerének becslése. Interdiszciplináris Magyar Egészségügy, XVII. évfolyam, 7. 34-41.

Net1: Sziviunk napja-a Sziv Világnapja. Letöltés: 2020.03.30. Web: http://www. szivunknapja.hu/
Net2: Egészségügyi sұürések, elöadások, szinnpadi programok - Szív Világnapja Nyíregyházán. Letöltés: 2020.03.30. Web: https://www.nyiregyhaza.hu/post/eg eszsegugyi-szuresek-eloadasokszinpadi-programok-sziv-vilagnapjanyiregyhazan-2019-09-30

Net3: Kardiovaszkuláris és tumorprevenció. Letöltés: 2020.03.30. Web: http:// semmelweis.hu/boe/prevencio/kardio vaszkularis-es-tumorprevencio/

Cicolini, G.; Simonetti, V.; Comparcini, D.; Celiberti, I.; Di Nicolad, M.; Capasso, L.M.; Flacco, M.E.; Bucci, M.; Mezzetti, A. \& Manzoli, L. (2013): Efficacy of a nurse-led email reminder program for cardiovascular prevention risk reduction in hypertensive patients: A randomized controlled trial. International Journal of Nursing Studies, 51(6), 833-843. doi: 10.1016/j.ijnurstu.2013. 10. 010

Net4: Magyar Egészségtervezoo" Alkalmazás. Látogatva: 2020.03.30. Web: https:// egterv.aeek.hu/ 


\title{
AZ EGÉSZSÉGMŰVELTSÉG ÉS A TÁPLÁLKOZÁSI SZOKÁSOK KÖZÖTTI ÖSSZEFÜGGÉS VIZSGÁLATA SERDÜLŐK KÖRÉBEN
}

\author{
Szerzők: \\ Tuza Alexandra \\ Debreceni Egyetem \\ Szőllősi Gergő József \\ Debreceni Egyetem \\ Szőnyi Krisztina \\ Debreceni Egyetem \\ Barth Anita \\ Debreceni Egyetem \\ Első szerző e-mail címe: \\ szandituza98@gmail.com
}

Lektorok:

Dr. Nagy Attila Csaba

Debreceni Egyetem

Dr. Legoza József

Debreceni Egyetem

...és további két anonim lektor

\begin{abstract}
Absztrakt
A fiatalkorban kialakuló nem megfelelő táplálkozási szokások felnőttkorban számos betegség kialakulásához vezethetnek. Célunk a serdülők egészségműveltségi szintjének feltérképezése és az ezt befolyásoló tényezők vizsgálata. Az egészségműveltség szintjének meghatározására a The Newest Vital Sign (NVS) tesztet használtuk. Szignifikáns összefüggést találtunk az egészségműveltségi szint és a rostos üdítőital fogyasztás között $(p=0,037)$. Magas a problémás egészségműveltséggel rendelkezők aránya, mely a rostos üdítőital fogyasztásával mutatott összefüggést.
\end{abstract}

Kulcsszavak: egészségműveltség, NVS, serdülők, táplálkozási szokások

Diszciplina: egészségtudomány

\begin{abstract}
MEASURING THE RELATIONSHIP BETWEEN

HEALTH LITERACY AND EATING HABITS AMONG ADOLESCENTS

Inadequate eating habits at a young age can lead many diseases in adulthood. The aim of the study was to measure the health literacy level of adolescents and to examine the
\end{abstract}


factors that may influence it. The health literacy level was measured with the Newest Vital Sign (NVS) test. We found a significant correlation between the level of health literacy and the consumption of soft drinks $(p=0,037)$. Inadequate health literacy was high among students, which was related to the consumption of soft drinks.

Keywords: health literacy, NVS, adolescents, eating habits

Disciplines: health science

Tuza Alexandra, Szőllősi Gergő József, Szőnyi Krisztina és Barth Anita (2020): Az egészségműveltség és a táplálkozási szokások közötti összefüggés vizsgálata serdülők körében. OxIPO - interdiszciplináris tudományos folyóirat, 2020/3, 19-29. doi: 10.35405/OXIPO.2020.3.19

A serdülők egészségmagatartásának és egészségműveltségi szintjének feltérképezése elengedhetetlen a hatékony egészségnevelési és egészségfejlesztési stratégiák kialakításához és azok módszertani fejlesztéséhez. Mind a lakosság (Papp és mtsai, 2016), mind pedig a serdülők (Nagy és mtsai, 2015) egészségműveltség vizsgálatára volt példa hazánkban, ugyanakkor legjobb tudásunk szerint az egészségmúveltség és az egészségmagatartás összefüggését vizsgáló kutatás még nem történt. A nemzetközi irodalomban fellelhető tanulmányok azonban rávilágítottak arra, hogy az egészségműveltség és az egészség- és rizikómagatartás között öszszefüggés áll fenn (Fleary, Joseph, és Pappagianopoulos, 2017).

Vizsgálatunkkal célunk a serdülők egészségműveltségének és egészségmagatartásának (különös tekintettel a táplálkozási szokásokra) feltérképezése, annak érdekében, hogy a vizsgált intézményekben célzott, személyre szabott intervenciók kerülhessenek kidolgozásra. A következőkben a serdülők körében végzett egészségműveltség vizsgálatokra, valamint az egészségmagatartást célzó felmérésekre fókuszálunk. Ismertetésre kerülnek továbbá keresztmetszeti kutatásunk legfrissebb eredményei is.

\section{AZ EGÉSZSÉGMƯVELTSÉG JELENTŐSÉGE A SERDÜLŐK KÖRÉBEN}

Az egészségműveltség és annak vizsgálata napjainkban egyre többet kutatott terület. Multidimenzionális fogalomként emlegetik. Egy tanulmány 17 különböző definícióját említi az egészségműveltségnek (Csizmadia, 2016; Nagy és mtsai, 2015). Leggyakrabban azonban a WHO fogalmát idézik, mely szerint az egészségműveltség „az emberek kognitív és szociális készsége (skills), amely meghatározza az egyének motivációját és az egyé- 
nek képességét (ability), amely segítségével hozzáférnek, megértik és felhasználják azokat az információkat, amelyek elősegítik és fenntartják jó egészségüket” (Csizmadia, 2016).

Az egészségműveltség mérésére számos mérőeszközt fejlesztettek ki. A nemzetközi irodalomban azonban több olyan teszt is található, amelyet az egészségműveltség mérésére használtak a serdülők körében. Egy napjainkban megjelent összefoglaló tanulmány összesen 29 db mérőeszközt mutat be részletesen azok előnyeivel, hátrányaival együtt (Guo és mtsai, 2018). A kérdőívek közül elsősorban az általunk is alkalmazott Newest Vital Sign (NVS) teszttel mért fontosabb nemzetközi eredményeket szeretnénk bemutatni.

Az NVS tesztet 2004-ben Weiss és munkatársai (Weiss és mtsai, 2005) fejlesztették ki a felnőttek egészségműveltségének vizsgálatára. A teszt szövegértési képességet, számolási készséget és problémamegoldó képességet egyaránt mér. A válaszadóknak összesen hat kérdésre kell válaszolniuk egy jégkrémes doboz táplálkozási adatait tartalmazó címke alapján. Összesen 6 pont szerezhető, a pontozás pedig az alábbiak szerint alakul:

0-1 pont: nagy valószínűséggel korláto zott,

2-3 pont: valószínúleg korlátozott,

4-6 pont: nagy valószínűséggel megfelelő egészségműveltségi szint.

Néhány évvel ezelőtt a teszt gyermekek és serdülők körében végzett sikeres validálását mutatták be (Driessnack és mtsai, 2014; Warsh és mtsai, 2013). Driessnack és munkatársai 7 éves kor fölötti gyermekek körében már ajánlják a teszt használatát, ezzel szemben Warsh és munkatársai úgy gondolják, hogy a teszt 10 éves kor fölött használható csak megbízhatóan. Driessnack és munkatársai által végzett felmérés érdekessége, hogy a tesztet nem csupán a gyermekek, de a szülők körében is felvették. A résztvevők $72 \%$-a nagy valószínűséggel megfelelő egészségműveltségi szinttel rendelkezik, tehát többségük a 6 pontból 4 vagy több pontszámot ért el. Nem mutattak ki szignifikáns különbséget a szülők (átlagpontszám $4,8 \pm 1,6$ ) és a gyermekeik (átlagpontszám

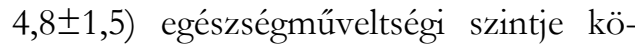
zött. Ugyanakkor közöttük pozitív korreláció volt tapasztalható. Mindemellett összefüggést találtak a háztartásban előforduló gyermekkönyvek száma és az egészségműveltségi szint között. Azokban a családokban, ahol 10-nél kevesebb gyermekkönyv fordult elő a gyermek és a szülő egyaránt alacsonyabb egészségmúveltségi szinttel rendelkezett, tehát valamennyi esetben 4 pontnál kevesebbet értek el (Driessnack és mtsai, 2014). Ezen eredmények hatására több országban alkalmazták sikeresen a tesztet a fiatalok körében.

Az Amerikai Egyesült Államokban a 6. osztályosok körében (átlagéletkor: 11,1士 0,24 év) végzett felmérés eredményei alapján elmondható, hogy a tanulók 62,9\%-a nagy valószínűséggel megfelelő, míg 12,6\%-a nagy valószínűséggel korlá- 
tozott egészségműveltségi szinttel rendelkezik. A maximális 6 pontból a vizsgálatban résztvevők 3,75 pontot értek el (szórás: 1,70). A nemek között szignifikáns különbség nem volt kimutatható (nő át-

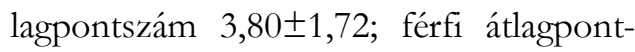

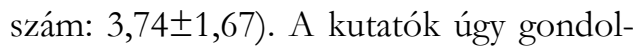
ják, hogy az NVS teszt önállóan is megállja a helyét úgy a klinikai gyakorlatban, mint az iskolai felhasználás során (Linnebur és Linnebur, 2016).

A nemzetközi irodalomban fellelhetô néhány, a serdülők körében végzett, kifejezetten az egészség- és rizikómagatartás, valamint az egészségműveltség összefüggését vizsgáló tanulmány is. Egy 2017-ben megjelenő áttekintő tanulmány azon kutatásokat gyűjtötte össze és elemezte, melyek középpontjában a serdülőkori egészségmagatartás, valamint az egészségmüveltség vizsgálata állt. Az eredmények pedig arra engednek következtetni, hogy a kettő szoros kapcsolatban áll egymással (Fleary, Joseph, és Pappagianopoulos, 2017).

\section{A SERDÜLŐK EGÉSZSÉGMAGATARTÁSÁT CÉLZÓ VIZSGÁLATOK}

A HBSC (Health Behaviour In Schoolaged Children) kutatás az Egészségügyi Világszervezettel együttműködésben zajló nemzetközi keresztmetszeti kutatás, amely az 5., 7., 9. és 11. osztályos diákok egészségmagatartását vizsgálja.
Hazánk először 1986-ban csatlakozott a négy évenkénti gyakorisággal ismétlődő kutatáshoz, melynek napjainkban már több mint 40 ország a tagja (Németh és Költő, 2011; Németh és Költő, 2016). A 2014-es felmérés során használt kérdőív az alábbi témaköröket érintette: egészségmagatartás (táplálkozási szokások, fizikai aktivitás, rizikómagatartások stb.), szubjektív jóllét (önértékelt egészség, krónikus betegségek és állapotok, élettel való elégedettség stb.) és háttértényezők (demográfia, család, kortársak stb.).

Összességében elmondható, hogy az évek során, hol pozitív, hol negatív változások következtek be a fiatalok táplálkozási szokásaiban, de ezek nem kielégítőek az egészségük szempontjából.

A hazai adatok azonban elszomorítóak. Közismert tény ugyanis, hogy a megfelelő mennyiségú és minőségű táplálékbevitel gyermekkorban a legjelentősebb, hiszen biztosítja az optimális növekedést és hozzájárul a szellemi fejlődéshez (Schaub és Bácsi, 2011). Helyes táplálkozással a betegségek egyharmada megelőzhető lenne. Ennek ellenére világszerte az egyik legfőbb probléma a zsírban és koleszterinben gazdag táplálkozás, amely különféle negatív hatásokhoz vezet. Az állandó és nagymértékü cukrozott üdítőitalok bevitelének szintén negatív irányú hatása van, hiszen sok fruktózt tartalmaznak, ami növeli a szérum húgysavat és a köszvény kockázatát (Choi és mtsai, 2007). A gyermekek körében egyre gyakoribb az elhízás, a 2-es típusú diabetes mellitus, vala- 
mint szív- és érrendszeri betegségek (Besenyei és mtsai, 2014; Cselik, 2017; Boros és mtsai, 2018).

\section{MÓDSZER}

\section{Minta}

A végleges mintanagyságot befolyásolta az adatfelvétel napján hiányzó tanulók, illetve a kérdőív kitöltését visszautasító

A vizsgálatban két intézmény 5., 7. és 9. évfolyamos tanulók ( $\mathrm{n}=206$ fö) vettek részt, akiknek átlagéletkora 13,89 év (szórás: 1,80) volt. A nemek megoszlásánál elmondható, hogy a résztvevők 53,88\%-a lány, 46,12\%-a fiú.

A legnagyobb arányban a 9. évfolyamról vettek részt a tanulók (5. évfolyam: 23,30\%; 7 évfolyam: 16,99\%; 9. évfolyam: 60,19\%). Az évfolyamok közötti nem egyenlő arányú megoszlás hátterében két tényező áll. Egyrészt az 5. és a 7. évfolyamon a kérdőív kitöltésének idején igen magas volt a hiányzók aránya, másrészt a 9. évfolyamon a teljes létszámot tekintve is jóval többen vannak, mint a vizsgált másik két évfolyamon.

A szülők iskolai végzettsége az alábbiak szerint alakult: az édesanyák 15,13\%-a alapfokú, 38,35\%-a középfokú és 46,12\%a pedig felsőfokú iskolai végzettséggel rendelkezik, az édesapák 14,56\%-a alapfokú, 40,29\%-a középfokú, 45,15\%-a felsőfokú iskolai végzettséggel rendelkezik (1. táblázat).
1. táblázat: $A$ résztvevoók $(n=206)$ szociodemográfiai adatai (forrás: a Szerzoók)

\begin{tabular}{lll}
\hline Változók & & Résztvevők \\
\hline Átlagéletkor & & $\begin{array}{l}13,89 \text { év } \\
\text { (szórás=1,80 év) }\end{array}$ \\
\hline Nem & Nő & $53,88 \%(\mathrm{~N}=111)$ \\
& Férfi & $46,12 \%(\mathrm{~N}=95)$ \\
\hline Évfolyam & 5. osztály & $23,30 \%(\mathrm{~N}=48)$ \\
& 7. osztály & $16,99 \%(\mathrm{~N}=35)$ \\
& 9. osztály & $60,19 \%(\mathrm{~N}=124)$ \\
\hline Édesanya & Alapfokú & $15,13 \%(\mathrm{~N}=32)$ \\
iskolai & Középfokú & $38,35 \%(\mathrm{~N}=79)$ \\
végzettsége & Felsőfokú & $46,12 \%(\mathrm{~N}=95)$ \\
\hline Édesapa & Alapfokú & $14,56 \%(\mathrm{~N}=30)$ \\
iskolai & Középfokú & $40,29 \%(\mathrm{~N}=83)$ \\
végzettsége & Felsőfokú & $45,15 \%(\mathrm{~N}=93)$ \\
\hline
\end{tabular}

\section{Eszközök}

A papír alapú kérdőív kitöltése a tanulók számára önkéntes és anonim volt. A kérdőív összesen 3 nagy témakört érintett. A kérdőív első része a szocio-demográfíai adatokra vonatkozó kérdéseket tartalmazta és az alábbi területekre kérdezett rá: nem, életkor, osztály, lakóhely, szülők iskolai végzettsége.

A második részben az egészségmagatartásra vonatkozó kérdések találhatók. A kérdések alapjául a HBSC kutatások során alkalmazott kérdőív kérdései szolgáltak. Beválogatásra kerültek a táplálkozás minőségére vonatkozó alábbi kérdések:

- „Hány alkalommal fogyasztasz gyümölcsöt?”

- „Hány alkalommal fogyasztasz zöldséget?"

- „Hány alkalommal fogyasztasz teljes kiőrlésű kenyeret/graham/?” 
- „Hány alkalommal fogyasztasz gyorséttermi ételeket?”

- „Hány alkalommal fogyasztasz édességet (csokoládé, cukor, sütemény)?”

- „Hány alkalommal fogyasztasz rágcsálnivalót (chips, mogyoró)?”

- „Hány alkalommal fogyasztasz rostos üdítőitalt (Sió, Rauch)?”

- „Hány alkalommal fogyasztasz szénsavas üdítőitalt (kóla, Fanta)?”

- „Hány alkalommal fogyasztasz szénsavasmentes vizet?”

- „Hány alkalommal fogyasztasz energiaitalt?"

- „Hány alkalommal fogyasztasz kávét?"

A kérdőív harmadik részben található az egészségműveltséget mérő teszt, mely a szövegértési képességet, a számolási készséget és a problémamegoldó képességet is méri. A válaszadóknak hat kérdést kell megválaszolniuk egy jégkrémes doboz táplálkozási adatait tartalmazó címke segítségével. Az első négy kérdés méri elsősorban az alapvető számolási készséget:

- „Ha megeszi az egész doboz jégkrémet, mennyi kalóriát fogyaszt el?"

- „Ha 60 g szénhidrátot fogyaszthat édesség gyanánt, mennyit ehet meg a dobozból?"

- „Orvosa azt tanácsolta, hogy csökkentse a telített zsírok fogyasztását. Általában 42 g telített zsírt fogyaszt, beleértve 1 adag jégkrémet is. Ha nem enne többé jégkrémet, hány gramm telített zsírt fogyasztana naponta?”
- „Ha naponta átlagosan 2500 kalóriát fogyaszt, akkor egy adag jégkrém elfogyasztása ennek mekkora hányadát (hány százalékát) teszi ki?”

Az utolsó két kérdés pedig a kitöltő szövegértési képességéről ad tájékoztatást:

• „Tegyük föl, hogy Ön allergiás a következőkre: penicillin, mogyoró, latex kesztyű, méhcsípés. Ennek tudatában biztonságos-e, ha eszik ebből a jégkrémből?"

- „Miért?”

Ugyanakkor minden kérdés az egyén problémamegoldó képességéről is információt ad. A Newest Vital Sign teszt alapján (ahol összesen 6 pont volt szerezhetô) három kategóriába lehet besorolni a tanulókat egészségmûveltségi szintjük alapján, ezek pedig a következők: nagy valószínűséggel megfelelő (4-6 pont), valószínűleg korlátozott (2-3 pont) és nagy valószínűséggel korlátozott (0-1pont).

\section{Eljárás}

Csoportos mintavételi eljárás keretében került sor az adatfelvételre 2019 márciusmájus hónapjaiban. A kérdőívek kitöltése az iskolai osztálytermekben történt, osztályfőnöki óra keretén belül, előre egyeztetett időpontban. Az adatfelvétel hossza osztályonként változott: az 5. osztályos tanulóknál körülbelül egy iskolai tanórát, azaz 45 percet, még a 7 . osztályosnál 30 percet, a 9. osztályos diákoknál pedig 15 20 percet vett igénybe. A felmérés kitöltése során személyesen is jelen voltunk, így a felmerülő kérdésekre választ adhattunk. 
Az adatok feldolgozása és elemzése a Stata Statistical Software: Release 13. statisztikai szoftvercsomag alkalmazásával történt. A kérdésekre adott válaszok a megjelölt válaszok függvényében részarányokkal (\%) kerülnek bemutatásra. A kategorikus változók gyakoriságbeli eltéréseit Khí-négyzet próbák segítségével értékeltük. Az eredmények közötti eltérést abban az esetben tekintettük szignifikánsnak, ha az adott statisztikai eljárásból származó p-érték kisebb volt, mint 0,05.

\section{Eredmények}

A serdülök táplálkozási szokásai

A táplálkozás minőségére vonatkozó eredmények könnyebb értelmezhetősége miatt az egyes változók esetében két kategóriát hoztunk létre: ajánlásoknak megfelelő, ajánlásoknak nem megfelelő táplálkozás. A kategóriák létrehozásánál figyelembe vettük a magyar táplálkozási ajánlásokat. Mindezek alapján elmondható (v.ö.: 2. táblázat), hogy az ajánlásoknak megfelelően, tehát naponta egyszer vagy annál

2. táblázat: A vizsgálatban rész̧vevö tanulók táplálkozási szokásai $(N=206)$. Forrás: a Szerzőo

\begin{tabular}{|c|c|c|c|c|c|}
\hline \multirow[b]{2}{*}{ TERMÉK } & \multicolumn{5}{|c|}{ A FOGYASZTÁS GYAKORISÁGA } \\
\hline & $\begin{array}{l}\text { Naponta } \\
\text { többször }\end{array}$ & $\begin{array}{c}\text { Naponta } \\
\text { egyszer }\end{array}$ & $\begin{array}{l}\text { Hetente } \\
\text { legalább } \\
\text { egyszer }\end{array}$ & $\begin{array}{l}\text { Ritkábban, } \\
\text { mint hetente }\end{array}$ & Soha \\
\hline Rostos üdítőital & $\begin{array}{c}6,76 \% \\
(\mathrm{~N}=14)\end{array}$ & $\begin{array}{l}26,57 \% \\
(\mathrm{~N}=55)\end{array}$ & $\begin{array}{l}38,65 \% \\
(\mathrm{~N}=80)\end{array}$ & $\begin{array}{l}19,81 \% \\
(\mathrm{~N}=41)\end{array}$ & $\begin{array}{l}8,21 \% \\
(\mathrm{~N}=17)\end{array}$ \\
\hline Szénsavas üdítőital & $\begin{array}{l}7,73 \% \\
(\mathrm{~N}=16)\end{array}$ & $\begin{array}{l}24,15 \% \\
(\mathrm{~N}=50)\end{array}$ & $\begin{array}{l}42,51 \% \\
(\mathrm{~N}=88)\end{array}$ & $\begin{array}{l}18,36 \% \\
(\mathrm{~N}=38)\end{array}$ & $\begin{array}{l}7,25 \% \\
(\mathrm{~N}=15)\end{array}$ \\
\hline Szénsavmentes víz & $\begin{array}{l}55,34 \% \\
(\mathrm{~N}=114)\end{array}$ & $\begin{array}{l}22,33 \% \\
(\mathrm{~N}=46)\end{array}$ & $\begin{array}{l}9,71 \% \\
(\mathrm{~N}=20)\end{array}$ & $\begin{array}{l}4,37 \% \\
(\mathrm{~N}=9)\end{array}$ & $\begin{array}{l}8,25 \% \\
(\mathrm{~N}=17)\end{array}$ \\
\hline Energiaital & $\begin{array}{l}4,88 \% \\
(\mathrm{~N}=10)\end{array}$ & $\begin{array}{l}9,76 \% \\
(\mathrm{~N}=20)\end{array}$ & $\begin{array}{l}16,59 \% \\
(\mathrm{~N}=34)\end{array}$ & $\begin{array}{l}17,56 \% \\
(\mathrm{~N}=36)\end{array}$ & $\begin{array}{c}51,22 \% \\
(\mathrm{~N}=105)\end{array}$ \\
\hline Kávé & $\begin{array}{l}2,90 \% \\
(\mathrm{~N}=6)\end{array}$ & $\begin{array}{l}10,14 \% \\
(\mathrm{~N}=21)\end{array}$ & $\begin{array}{l}15,46 \% \\
(\mathrm{~N}=32)\end{array}$ & $\begin{array}{l}13,53 \% \\
(\mathrm{~N}=28)\end{array}$ & $\begin{array}{c}57,97 \% \\
(\mathrm{~N}=120)\end{array}$ \\
\hline Gyümölcs & $\begin{array}{l}21,84 \% \\
(\mathrm{~N}=45)\end{array}$ & $\begin{array}{l}40,78 \% \\
(\mathrm{~N}=87)\end{array}$ & $\begin{array}{l}29,13 \% \\
(\mathrm{~N}=60)\end{array}$ & $\begin{array}{l}6,80 \% \\
(\mathrm{~N}=14)\end{array}$ & $\begin{array}{l}1,46 \% \\
(\mathrm{~N}=3)\end{array}$ \\
\hline Zöldség & $\begin{array}{l}11,59 \% \\
(\mathrm{~N}=24)\end{array}$ & $\begin{array}{l}45,41 \% \\
(\mathrm{~N}=94)\end{array}$ & $\begin{array}{l}35,75 \% \\
(\mathrm{~N}=74)\end{array}$ & $\begin{array}{l}5,80 \% \\
(\mathrm{~N}=12)\end{array}$ & $\begin{array}{l}1,45 \% \\
(\mathrm{~N}=3)\end{array}$ \\
\hline $\begin{array}{l}\text { Teljes kiörlésű } \\
\text { kenyér }\end{array}$ & $\begin{array}{l}18,36 \% \\
(\mathrm{~N}=38)\end{array}$ & $\begin{array}{l}29,47 \% \\
(\mathrm{~N}=61)\end{array}$ & $\begin{array}{l}20,29 \% \\
(\mathrm{~N}=42)\end{array}$ & $\begin{array}{l}14,49 \% \\
(\mathrm{~N}=30)\end{array}$ & $\begin{array}{l}17,39 \% \\
(\mathrm{~N}=36)\end{array}$ \\
\hline Gyorséttermi étel & $\begin{array}{l}1,94 \% \\
(\mathrm{~N}=4)\end{array}$ & $\begin{array}{l}4,37 \% \\
(\mathrm{~N}=9)\end{array}$ & $\begin{array}{l}31,55 \% \\
(\mathrm{~N}=65)\end{array}$ & $\begin{array}{l}54,85 \% \\
(\mathrm{~N}=113)\end{array}$ & $\begin{array}{l}7,28 \% \\
(\mathrm{~N}=15)\end{array}$ \\
\hline Édesség & $\begin{array}{l}13,59 \% \\
(\mathrm{~N}=28)\end{array}$ & $\begin{array}{l}44,17 \% \\
(\mathrm{~N}=91)\end{array}$ & $\begin{array}{l}33,50 \% \\
(\mathrm{~N}=69)\end{array}$ & $\begin{array}{c}6,80 \% \\
(\mathrm{~N}=14)\end{array}$ & $\begin{array}{l}1,94 \% \\
(\mathrm{~N}=4)\end{array}$ \\
\hline Sós rágcsálnivaló & $\begin{array}{l}9,18 \% \\
(\mathrm{~N}=19)\end{array}$ & $\begin{array}{l}24,15 \% \\
(\mathrm{~N}=50)\end{array}$ & $\begin{array}{l}52,66 \% \\
(\mathrm{~N}=109)\end{array}$ & $\begin{array}{l}11,59 \% \\
(\mathrm{~N}=24)\end{array}$ & $\begin{array}{l}2,42 \% \\
(\mathrm{~N}=5)\end{array}$ \\
\hline
\end{tabular}


többször a tanulók 57,00\%-a zöldséget, 62,62\%-a gyümölcsöt és $77,67 \%$-a szénsavmentes vizet fogyaszt. Teljes kiölésû kenyeret naponta, vagy legalább hetente egyszer 68,12\%-a eszik a serdülőknek.

A gyorséttermi ételek esetében elmondható, hogy a tanulók 62,13\%-a ritkábban, mint hetente vagy egyáltalán nem fogyaszt ilyen ételeket. Az ajánlásoknak megfelelően, tehát hetente egyszer, vagy ennél is ritkábban a tanulók 42,24\%-a édességet, míg 66,67\%-a sós rágcsálnivalók eszik. Ritkábban, mint hetente a tanulók 19,81\%-a rostos üdítőt, 25,61\%-a pedig szénsavas üdítőt fogyaszt. Soha nem iszik energiaitalt a tanulók 51,22\%-a, kávét a tanulók pedig 57,97\%-a (2. táblázat).

\section{A serdülōk egészségmüveltségi szintje}

Az NVS teszt alapján a vizsgálatban részt vevő fiatalok 50,49\%-a nagy valószínűséggel megfelelő, 23,30\%-a valószínúleg korlátozott, míg 26,21\%-a nagy valószínűséggel korlátozott kategóriába került (1. ábra).

Az egészségmúveltségre vonatkozó eredmények könnyebb értelmezhetősége miatt két kategóriát hoztunk létre: az NVS teszten 4 vagy annál magasabb pontszám elérése esetén az egyén a megfelelő, míg ez alatti pontszám esetén a nem megfelelő egészségműveltségi kategóriába került. Ez alapján az alábbiak szerint alakul a százalékos megoszlás: A tanulók 50,49\%-a megfelelő egészségműveltségi kategóriába kerül, míg 49,51\%-a nem megfelelő egészségműveltségi kategóriába esik.
1. ábra: A serdülōk egészségmüveltségi szintje (N=206). Forrás: a Szerzőo

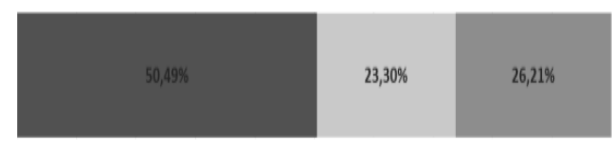

- nagy valószinüséggel megfelelö "| valószinüleg korlátozott In nagy valószinüséggel korlátozott

Nem találtunk szignifikáns összefüggést a két intézmény tanulói között az egészségműveltség vonatkozásában $(\mathrm{p}=0,376)$. A következőkben ezért a két intézmény tanulóit egy egységként kezeljük, az összefüggéseket pedig a teljes mintára vonatkozóan $(\mathrm{N}=206)$ mutatjuk be.

Összességében elmondható, hogy nem találtunk szignifikáns összefüggést az egészségműveltség és a zöldség-, gyümölcs-, teljes kiőrlésű kenyér, gyorséttermi ételek, édesség, valamint sós rágcsálnivaló fogyasztása között. A szénsavas üdítőital, szénsavmentes víz, energiaital, valamint a kávé fogyasztása sem bizonyult befolyásoló tényezőnek.

Ugyanakkor szignifikáns összefüggést találtunk az egészségműveltség és a rostos üdítőital fogyasztás közötti $(p=0,037)$. Azok a serdülők, akik megfelelő egészségműveltségi kategóriába esnek, nagyobb valószínűséggel fogyasztanak az ajánlásoknak megfelelően rostos üdítőitalt a nem megfelelő egészségműveltségi kategóriába eső serdülőkhöz képest (2. ábra). 
2. ábra: Az egészségmüveltség és a rostos üdítôital fogyasztás közötti összefüggés ( $N=206)$. Forrás: a Szerző́k

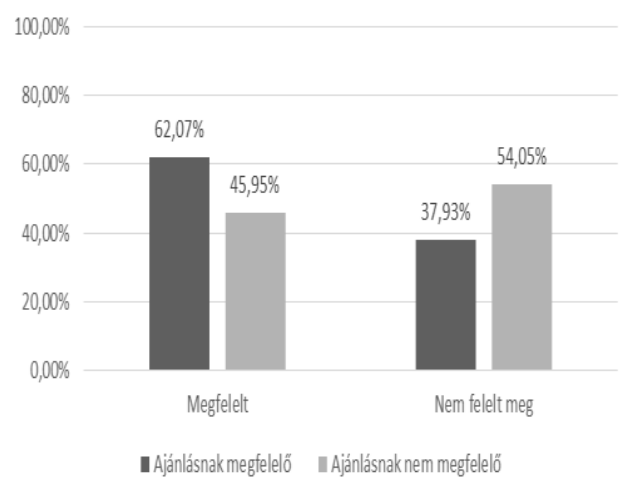

\section{MEGVITATÁS}

Összességében elmondható, hogy a tanulók esetében a teljes kiőrlésű pékáruk, valamint a szénsavmentes víz fogyasztása közelít leginkább az ajánlásokhoz. Javítandó azonban a gyümölcs-, a zöldségfogyasztás. Csökkentésre szorul a kávé-, az energiaital-, az édesség-, a sós rágcsálnivalók-, a gyorséttermi ételek-, valamint a rostos- és szénsavas üdítőitalok fogyasztásának gyakorisága.

Ugyan a résztvevők fele nagy valószínűséggel megfelelő egészségműveltséggel rendelkezik, nem szabad figyelmen kívül hagyni azt a tényt, hogy a nemzetközi eredményekkel összevetve a vizsgálatunkban részt vevő tanulók rosszabb eredményeket értek el az egészségmúveltség vonatkozásában (Linnebur és Linnebur, 2016). Az egészségműveltség és a táplálkozás minősége közötti összefüggéseket vizsgálva a rostos üdítőital tekintetében találtunk szignifikáns összefüggést ( $p=0,037)$. Úgy tűnik tehát, hogy azok a tanulók, akik magasabb egészségműveltségi kategóriába tartoznak a rostos üdítőitallal kapcsolatos ajánlásokkal jobban tisztában vannak, ezért kerülik annak fogyasztását.

\section{KORLÁTOZÁSOK}

Esetünkben egy anonim kérdőíves felmérésről van szó, mely felmérésnek végleges mintanagyságát a mintavétel napján hiányzott tanulók létszáma, illetve a kitöltést megtagadó tanulók létszáma befolyásolta. A kapott eredményekből nem vonhatóak le általános következmények, csupán az adott intézmények tanulóira vonatkoztathatóak az eredmények. Mivel a választott egészségműveltséget mérő kérdőívvel nem állnak rendelkezésre hazai, iskoláskorúak körében végezett vizsgálatok, így nincs lehetőség eredményeink összevetésére hazai vizsgálatok eredményeivel.

\section{KONKLÚZIÓK}

A vizsgált intézményekben vannak fejlesztésre szoruló területek - mind az egészséges táplálkozás, mind pedig az egészségműveltség vonatkozásában. Ennek javítása érdekében kiemelt jelentőségû az egészségtudatosság javítása, az egészségmagatartás fejlesztése a különféle egészségnevelési és egészségfejlesztési 
programok fejlesztését célzó intézkedések révén. Fontos nem csupán a tanulók, de a szülők körében történő felvilágosítás, tájékoztatás is, annak érdekében, hogy valódi, mérhető változás következzen be.

A jövőben nagyobb, reprezentatív mintán érdemes a vizsgálatot megismételni.

\section{IRODALOM}

Besenyi G., Barczi Sz., Pongor V. és Forrai J. (2014). Általános iskolás tanulók táplálkozási- és egészségmagatartási szokásai. Egészségtudomány, (58)2. 3648.

Boros J., Györke J., Stokker E. és Szabó Zs. (2018). A 2014-ben végrehajtott Európai lakossági egészségfelmérés eredményei Összefoglaló adatok. ELEF Mühelytanulmány I. Központi Statisztikai Hivatal, Budapest.

Choi, J. W. J., Ford, E. S., Gao, X., és Choi, H. K. (2007). Sugar-sweetened soft drinks, diet soft drinks, and serum uric acid level: The third national health and nutrition examination survey. Arthritis \& Rheumatism, 59(1), 109-116. DOI: $\underline{10.1002 / \text { art.23245 }}$

Cselik B. (2017). Egészségfejlesz̨tő program hatása általános iskolás diákok egészségmagatartására (,Fitness”, vagy ,fatness”?! Avagy nem lehet elég korán kezdeni). Doktori (Ph.D.) értekezés. Pécsi Tudományegyetem Egészségtudományi Kar, Doktori Iskola, Pécs.
Csizmadia P. (2016). Az egészségműveltség definíciói. Egészségfejlesz̨tés, (57)3. 41-44.

Driessnack, M., Chung, S., Perkhounkova, E. és Hein, M. (2014). Using the "Newest Vital Sign" to Assess Health Literacy in Children. Journal of Pediatric Health Care, 28(2), 165-171. DOI: 10.1016/j.pedhc. 2013.05.005

Fleary, S. A., Joseph, P. és Pappagianopoulos, J. E. (2017). Adolescent health literacy and health behaviors: A systematic review. Journal of Adolescence, 62, 116-127. DOI: 10.1016/j.adolescence.2017.11.010

Guo, S., Armstrong, R., Waters, E., Sathish, T., Alif, S. M., Browne, G. R. és Yu, X. (2018). Quality of health literacy instruments used in children and adolescents: a systematic review. BMJ Open, 8(6), e020080. DOI: 10.1136/bmjopen-2017-020080

Linnebur, L. A., Linnebur, S. A. (2016). Self-Administered Assessment of Health Literacy in Adolescents Using the Newest Vital Sign. Health Promotion Practice, 19(1), 119-124. DOI: $\underline{10.1177 / 1524839916677729}$

Nagy L., Korom E., Hódi Á. és Németh M. (2015). Az egészségműveltség online mérése. In: Csapó B. és Zsolnai A. (szerk.): Online diagnosztikus mérések az iskola kezdô" szakaszában. Oktatáskutató és Fejlesztő Intézet, Budapest. 147177. 
Németh Á. és Költő A. (2011). Serdülókorú fiatalok egészsége és életmódja. Az Iskoláskorú gyermekek egészségmagatartása címü, az Egészségügyi Világszervezettel együttmüködésben zajló nemzetközi kutatás 2010. évi felméréséröl keészült nemzeti jelentés. Országos Gyermekegészségügyi Intézet, Budapest.

Németh Á. és Költő A. (2016). Egészség és egészségmagatartás iskoláskorban. Az Iskoláskorú gyermekek egészségmagatartása elnevezésü, az. Egészségügyi Világszervezettel együttmüködésben megvalósuló nemzetközi kutatás 2014. évi felméréséröl készült nemzeti jelentés. Nemzeti Egészségfejlesztési Intézet, Budapest.

Papp O., Náfrádi L., Schulz P. és Csabai M. (2016). „Hogy minden beteg megértse!" - Az egészségműveltség (health literacy) mérése Magyarországon. Orvosi Hetilap, 157(23). 905-915.
Schaub G. és Bácsi K. (2011). Táplálkozási szokások nemzetközi összehasonlítása 10-12 éves gyermekek körében. Iskolakultura, 2011/10-11. 138-146.

Warsh, J., Chari, R., Badaczewski, A., Hossain, J. és Sharif, I. (2013). Can the Newest Vital Sign Be Used to Assess Health Literacy in Children and Adolescents? Clinical Pediatrics, 53(2), 141-144. DOI: $10.1177 / 0009922813$ $\underline{504025}$

Weiss, B. D., Mays, M. Z., Martz, W., Castro, K. M., DeWalt, D. M., Pignone, M. P., Mockbee, J., és Hale, F. A. (2005). Quick Assessment of Literacy in Primary Care: The Newest Vital Sign. The Annals of Family Medicine, 3(6), 514-522. DOI: $\underline{10.1370 / \mathrm{afm} .405}$ 


\title{
FIATALOK SZEXUÁLIS MAGATARTÁSÁNAK VIZSGÁLATA GIMNÁZIUMBAN TANULÓK KÖRÉBEN - EGY VIZSGÁLAT KEZDETI EREDMÉNYEI
}

\section{Szerző:}

Hegedűs Réka Dóra

Debreceni Egyetem

Barth Anita

Debreceni Egyetem

Szerdi Márta

Debreceni Egyetem

Szőllősi Gergő József

Debreceni Egyetem

\section{Lektorok:}

Dr. Kiss János

Debreceni Egyetem

Dr. Huszti Éva

Debreceni Egyetem

...és további két anonim lektor

Első szerző e-mail címe:

hegereka95@gmail.com

\begin{abstract}
Absztrakt
Jelen kutatás célja gimnáziumi tanulók szexuális magatartásának feltérképezése és annak vizsgálata, hogy mennyire hatékony a kiválasztott intézményben a szexuális nevelés. A vizsgálatban összesen 300 fő vett részt. A tanulók átlagéletkora 17,51 év (szórás: 1,38) volt. A kapott eredményeink alapján elmondható, hogy a tanulók közel fele 15 évesen, vagy annál fiatalabb életkorban kezd nemi életet élni. Ugyan a leggyakrabban alkalmazott fogamzásgátló módszer a kondom volt körükben a legutóbbi aktus során, igen magas azok aránya, akik egyáltalán nem védekeztek.
\end{abstract}

Kulcsszavak: szexuális magatartás, serdülők, gimnázium

Diszciplina: társadalomtudomány

\section{Abstract}

A STUDY OF YOUNG PEOPLE'S SEXUAL BEHAVIOUR

AMONG HIGH SCHOOL STUDENTS - A STUDY WITH INITLAL RESULTS

The aim of the present study is to measure the sexual behaviour of high school students and to examine the effectiveness of sex education in the selected institution. A total of 300 people participated in the study. The mean age of the students was 17.51 
years (standard deviation: 1.38). Nearly half of the students start having sex at the age of 15 or younger. Although the most commonly used method of contraception was the condom among them during the last act, the proportion of those who did not defend themselves at all was very high.

Keywords: sexual behavior, adolescents, high school

Disciplines: social sciences

Hegedűs Réka Dóra, Barth Anita, Szerdi Márta és Szőllősi Gergő József (2020): Fiatalok szexuális magatartásának vizsgálata gimnáziumban tanuló fiatalok körében - egy vizsgálat kezdeti eredményei. OxIPO - interdiszciplináris tudományos folyóirat, 2020/3, 3141. doi: 10.35405/OXIPO.2020.3.31

A serdülőkor egy átmeneti időszak a gyermek- és felnőttkor között, amely során mentális, fizikális és szociális változások zajlanak le. A serdülőkori problémákat a hormonális és pszicho-szociális folyamatok adják, amit tovább ronthatnak a hangulati ingadozások, fokozott érzékenység. Egy serdülő számára kihívást jelent a nemi szerepek elsajátítása, identitás kialakítása és a társas kapcsolatok átalakulása (Rice és Mulkeen, 1995). Ebben az időszakban próbálja megtalálni a saját értékeit, helyét a társadalomban. Ha ez nem sikerül, ha nem találja meg a megfelelő szerepet, vagy nem találja meg a helyét, akkor összezavarodhat, ez pedig konfúziót eredményez (Erikson, 1968). A serdülőkorban hozott helytelen döntések negatív hatással lehetnek az egyén későbbi életére. Jelen kutatás célja felmérni egy hajdúszoboszlói intézmény felső tagozatos tanulóinak szexuális magatartását. A kö- vetkezőkben az Olvasó a serdülők szexuális magatartásával foglalkozó vizsgálatokkal és azok eredményeiről tájékozódhat. Mindemellett bemutatásra kerülnek a vizsgálat kezdeti eredményei is.

\section{A SERDÜLŐK SZEXUÁLIS MAGATARTÁSÁT CÉLZÓ VIZSGÁLATOK}

Több hazai és nemzetközi kutatás is megcélozta a fiatalok szexuális szokásainak, viselkedésének vizsgálatát. E kutatások alapján elmondható, hogy a serdülők a szexuális életet egyre korábban kezdik. Az Egyesült Államokban végzett 2013-as kutatás eredményei alapján megállapítható, hogy a 15-16 éves lányok jelentős százalékának volt már szexuális kapcsolata (Finer és Philbin, 2013). Korai szexuális aktivitás figyelhető meg Svédországban is, ahol a megkérdezettek egyharmadának 
volt már szexuális kapcsolata. A svéd lányok 23\%-nak, míg a fiúk 20\%-nak 14 vagy annál fiatalabb korban volt az első szexuális kapcsolata (Makenzius és Larsson, 2013). Hazánkban pécsi középiskolások körében végzett kutatás eredményei alapján elmondható, hogy a tanulók átlagos életkora az első szexuális kapcsolat során 15 év volt (Jäger és Tigyi, 2012). Egy kiskunhalasi gimnáziumban végzett felmérés szerint a fiúk átlagosan 15 évesen, a lányok 16 évesen veszítették el a szüzességüket (Rácz és Németh, 2015). A több országra kiterjedő, egyik legjelentősebb nemzetközi felmérés, a HBSC kutatás, amelynek célja az iskoláskorúak egészségmagatartásának vizsgálata, a kortárskapcsolatokat, ideértve a szexuális magatartás és a romantikus tapasztalatok feltérképezését is célul tűzte ki. A legutóbbi 2014-es felmérés eredményei alapján elmondható, hogy Magyarországon a tanulók 45\%-nak már volt szexuálisan aktív kapcsolata, a két nemnél közel azonos arányban (fiúk 46\%; lányok 45\%). Évfolyam szerint vizsgálva, megállapítható, hogy az idősebb életkorban a tanulók között szignifikánsan nagyobb a szexuálisan aktív tanulók aránya. A 9. évfolyamban 8\%-kal több fiú, a 11. évfolyamon 5\%-kal több lány él szexuálisan aktív életet. A szexuálisan aktív tanulók leggyakrabban óvszerrel védekeznek. A válaszadók 48\%a önmagában, 18\%-a pedig más módszerrel kombinálva használt óvszert a szexuális együttlét során. Az óvszer használat a korábbi vizsgálatokhoz képest 10\%-kal csökkent, viszont a kombinált módszert alkalmazók köre 3\%-kal emelkedett. A 2006-os vizsgálat óta a nem védekezők aránya folyamatosan nő. Az utolsó szexuális együttlét során a nem védekezők aránya 2006-ban 7\%, 2010-ben 10\%, 2014 ben pedig 14\% körül volt (Németh és Költő, 2016). A korai szexuális élet a nem kívánt terhességek számának emelkedését is eredményezheti. Egy 21 országra kiterjedő nemzetközi összehasonlító vizsgálat alapján, Magyarországon kiemelkedően magas a 10-14 év közötti lányok terhességének aránya, a terhesség megszakítások és kihordott terhességek számát tekintve. A 21 vizsgált ország közül második helyen hazánk áll (Sedgh és mtsai, 2015).

\section{SZEXEDUKÁCIÓS ÉS FELVILÁGOSÍTÓ PROGRAMOK MAGYARORSZÁGON}

Magyarországon a szexuális nevelés a pedagógia számos más területéhez képest kissé elhanyagolt terület. Az Országos Egészségfejlesztési Intézet 2010-ben végzett reprezentatív kutatása során megállapította, hogy az iskolai szexuális nevelés komoly fejlesztésre szorul hazánkban. A kezdetekben főleg amerikai programokat adaptáltak Magyarországon. Ilyen program volt a középiskolai egészségnevelési program, melyet Susan Shapiro és Carol Flaherty dolgoztak ki. Ennek keretében került sor a 12-18 évesek egészségnevelésére, az alábbi területekre fókuszálva: szexuális nevelés, alkohol és drog megelőzés, 
egészséges táplálkozás, dohányzás prevenció. Később magyar szerzők is készítettek edukációs programokat. Ilyen volt Csendes Éva Magyarországon megvalósult szex edukációs programja a „Beszéljünk erről...”, a „Fiatalok az élet küszöbén”, az „A-HA!” Országos Szexuális és Mentálhigiénés Felvilágosító programja és a Szex Edukációs Alapítvány programja. A legtöbb program megjelent kézikönyv formájában, a fiatalok hatékony oktatásának elősegítése érdekében. Ugyanakkor néhány honlaphoz interaktív CD, szórólap, weblapok is tartoznak, mely a könynyebb elérést teszi lehetővé. A különféle programban az oktatói szerepet a védőnők, orvostanhallgatók és nőgyógyászok töltik be (Simich és Fábián, 2010).

\section{MÓDSZER}

\section{Minta}

Vizsgálatunkat egy vidéki gimnázium tanulói körében végeztük. A minta lehetséges elemszáma 306 fő. A végleges mintanagyságot befolyásolta az adatfelvétel napján hiányzó tanulók, illetve a kérdőív kitöltését visszautasító tanulók száma.

A vizsgálatban végül összesen 300 fő vett részt. A válaszadók átlagéletkora 17,5 év (szórás: 1,38) volt. A nemek megoszlása az alábbiak szerint alakult: 37\%-a $(\mathrm{N}=110)$ fiú, 63\%-a $(\mathrm{N}=190)$ lány. A tanulók 25\%-a $(\mathrm{N}=75)$ 9. évfolyamos, 22\%a $(\mathrm{N}=67)$ 10. évfolyamos, 20\%-a $(\mathrm{N}=59)$
11. évfolyamos és 33\% (N=99) 12. évfolyamos volt (1. táblázat).

1. táblázat: a résztvevök szociodemográfiai adatai (n=300). Forrás: a Szerzőolk

\begin{tabular}{|l|l|r|}
\hline \multicolumn{2}{|c|}{$\begin{array}{c}\text { Válto } \\
\text { zók }\end{array}$} & \multicolumn{1}{c|}{ Elemszám } \\
\hline Életkor & Átlagéletkor & 17,51 év \\
\hline \multirow{2}{*}{ Nem } & Lány & $63,33 \%(\mathrm{~N}=190)$ \\
\cline { 2 - 3 } & Fiú & $36,67 \%(\mathrm{~N}=110)$ \\
\hline \multirow{3}{*}{$\begin{array}{l}\text { Év- } \\
\text { folyam }\end{array}$} & 9. évfolyam & $25,00 \%(\mathrm{~N}=75)$ \\
\cline { 2 - 3 } & 10. évfolyam & $22,33 \%(\mathrm{~N}=67)$ \\
\cline { 2 - 3 } & 11. évfolyam & $19,67 \%(\mathrm{~N}=59)$ \\
\cline { 2 - 3 } & 12. évfolyam & $33,00 \%(\mathrm{~N}=99)$ \\
\hline
\end{tabular}

\section{Eszközök}

A kutatás során alkalmazott kérdőív két nagy témakört érintett. A kérdőív első része a szociodemográfiai adatokra vonatkozó kérdéseket tartalmazta, és az alábbi területekre kérdezett rá: nem, életkor, osztály, lakóhely, szülök legmagasabb iskolai végzettsége. A második rész a tanulók szexuális magatartására vonatkozó kérdéseket tartalmazta. A kérdőívben szereplő kérdések alapjául a HBSC (Iskoláskorú Gyermekek Egészségmagatartása) kutatások (Németh és Költő, 2016) során alkalmazott kérdőívek kérdései szolgáltak, melyek zárt, eldöntendő kérdések voltak. A kérdések között volt, az első szexuális kapcsolatra („Volt-e már szexuális kapcsolata?”, „Hány évesen volt az első sze- 
xuális kapcsolata?”), a legutóbbi alkalommal alkalmazott védekezési módra („A legutóbbi alkalommal használt-e te vagy a partnered óvszert?”, "A legutóbbi alkalommal használt-e te vagy a partnered fogamzásgátló tablettát?”, "A legutóbbi alkalommal használt-e te vagy a partnered megszakításos közösülést (coitus interruptus) védekezési módszert?”, „A legutóbbi alkalommal használt-e te vagy a partnered valamilyen más módszert a védekezésre?”) és a romantikus kapcsolatokra („Voltál-e már szerelmes valakibe?”, „Jártál-e már valakivel?”) vonatkozó kérdések.

\section{Eljárás}

Csoportos mintavételi eljárás keretében került sor az adatfelvételre 2020. január és február hónapjaiban. A papír alapú kérdőív kitöltése a tanulók számára önkéntes és anonim volt.

A kérdőívek kitöltése az iskolai osztálytermekben történt, osztályfőnöki óra keretén belül, előre egyeztetett időpontban. $\mathrm{A} z$ adatok feldolgozása és elemzése a Stata Statistical Software: Release 13. statisztikai szoftvercsomag alkalmazásával történt. A kérdésekre adott válaszok a megjelölt válaszok függvényében részarányokkal kerülnek bemutatásra. A kategorikus változók gyakoriságbeli eltéréseit Khí-négyzet próbák segítségével értékeltük. Az évfolyamok körében a szexuális aktivitás gyakoriságának vizsgálata Fishers-féle egzakt tesztekkel valósult meg. Az eredmények közötti eltérést ab- ban az esetben tekintettük szignifikánsnak, ha az adott statisztikai eljárásból származó p-érték kisebb volt, mint 0,05.

\section{EREDMÉNYEK}

Szexuális aktivitás

A válaszadók 35\%-nak (N=112) már volt szexuális kapcsolata. A szexuális kapcsolatot már létesített tanulókat nem valamint évfolyamok szerint is megvizsgáltuk. Nem találtunk szignifikáns különbséget a szexuális aktivitás tekintetében a nemek között $(\mathrm{p}=0,609)$. A fiúk 35\%-a míg a lányok 38\%-a létesített szexuális kapcsolatot élete során legalább egyszer (1. ábra).

Évfolyamok szerinti bontásban szignifikáns különbség figyelhető meg: az idősebb tanulók körében nagyobb a szexuálisan aktív tanulók aránya (2. ábra). A 9. évfolyamos tanulók 3\%-ának $(\mathrm{N}=2)$ volt szexuális kapcsolata, míg a 12. évfolyamon a tanulók körében ez az arány 66\% $(\mathrm{N}=65)$ volt $(\mathrm{p}<0,01)$.

\section{Szexuális élet kezdete}

A vizsgálatban résztvevő tanulók csupán 9\%-ának volt 14 évesen vagy annál fiatalabb életkorban az első szexuális kapcsolata. A tanulók többsége, 89\%-a 15 vagy annál idősebb életkorban szerezte első szexuális tapasztalatát (3. ábra). 
1. ábra: Szexuális kapcsolatot a nemek vonatkozásában (forrás: a szerzóke)

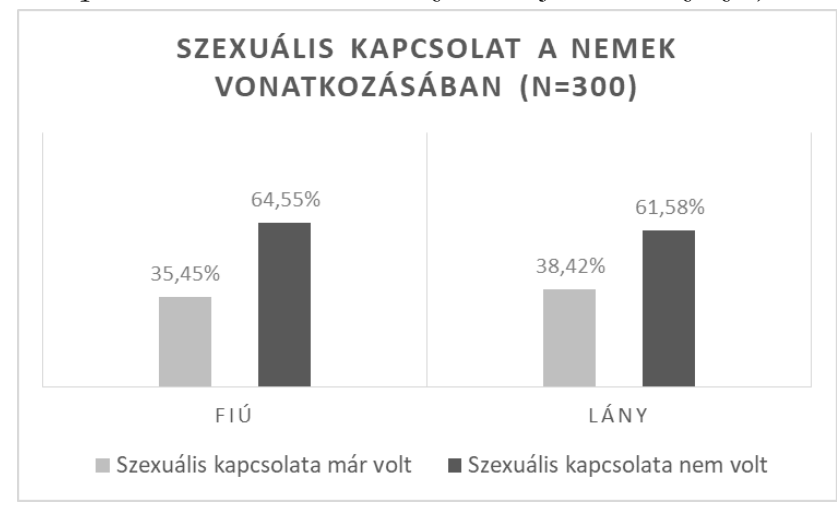

2. ábra: Szexuális kapcsolat az évfolyamok vonatkozásában (forrás: a szerzők)

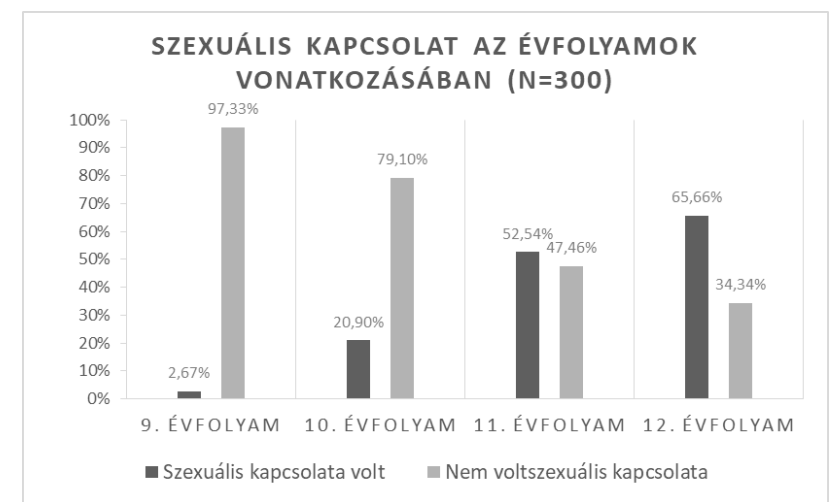

3. ábra: Életkor az elsô" szexuális kapcsolat idején (forrás: a szuerzőke)

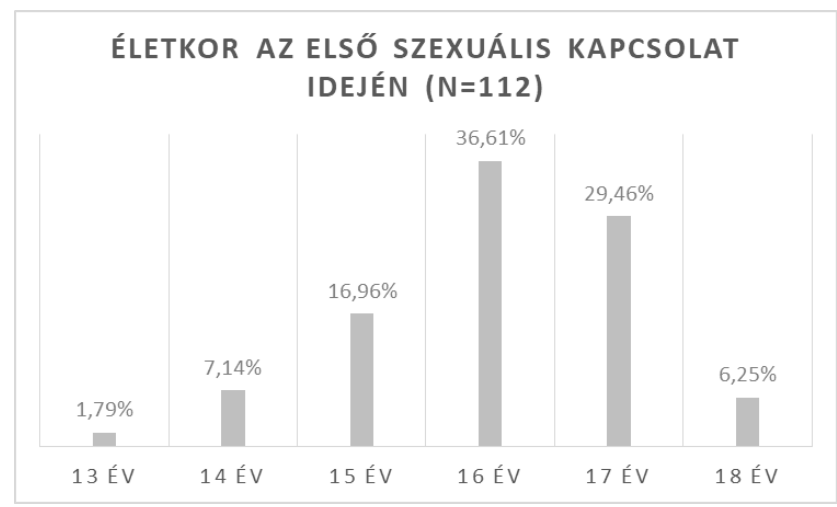




\section{Alkalmazott védekezési mód}

a legutóbbi aktus során

A szexuálisan aktív tanulók többsége $(72 \%)$ védekezett a legutóbbi szexuális aktus során. Ugyanakkor szignifikáns különbség figyelhető meg a nemek tekintetében. A fiúk nagyobb arányban alkalmaztak valamilyen védekezési módot a lányokhoz képest ( $p=0,070$ - vesd össze: 4 . ábra).

A legutóbbi szexuális együttlét alkalmával a tanulók többsége, 45\%-uk óvszert használt. Alacsony azon tanulók aránya, akik az óvszert egyéb védekezési módszerrel kiegészítve alkalmazták azt. Egyéb módszert (pl. fogamzásgátló tabletta) a tanulók 18\%-a alkalmazott.

Különbség figyelhető meg a fiúk és lányok között az egyes védekezési módok alkalmazásának arányában. A lányok esetében az alábbiak szerint alakulnak az arányok: 45\% óvszer; $7 \%$ óvszer és egyéb; 15\% egyéb; 33\% nem védekezett. A fiúk esetében pedig az alábbiak szerint alakulnak: 46\% óvszer; $13 \%$ óvszer és egyéb; 23\% egyéb; $18 \%$ nem védekezett. Összességében elmondható, hogy mindkét nem esetében a leggyakrabban alkalmazott védekezési mód az óvszer volt (fiúk: 46\%; lányok: 45\%) A nemek vonatkozásában elmondható, hogy az óvszerhasználat esetben nincs különbség a nemek között $(p=0,309)$. Ugyanakkor a fiúk gyakrabban használnak egyéb módszert, mint a lányok $(p=0,087)$. Mindemellett a lányok gyakrabban számoltak be védekezés nélküli szexuális kapcsolatról, mint a fiúk $(p=0,087)$ (5. ábra).

4. ábra: A legutóbbi szexuális együttlét során történö védekęés a nemek vonatkozásában (forrás: a szerzőo)

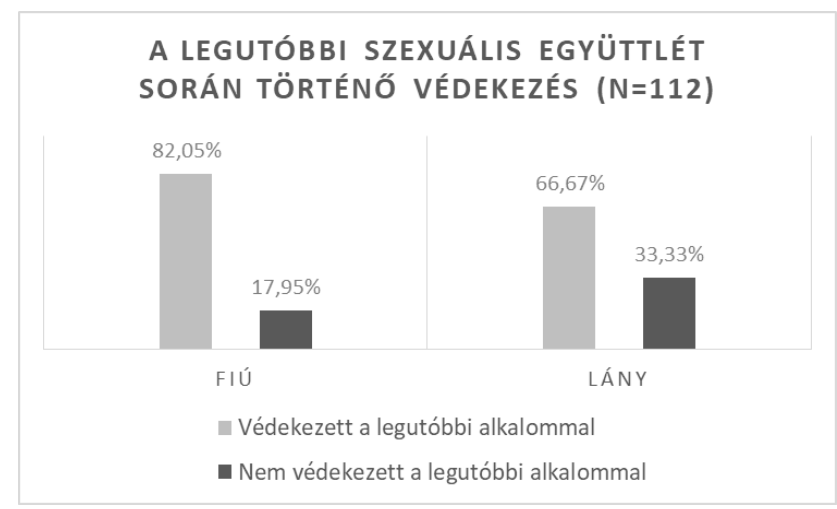


5. ábra: A legutóbbi szexuális együttlét során alkalmazott védekęési mód (forrás: a szerző́k)

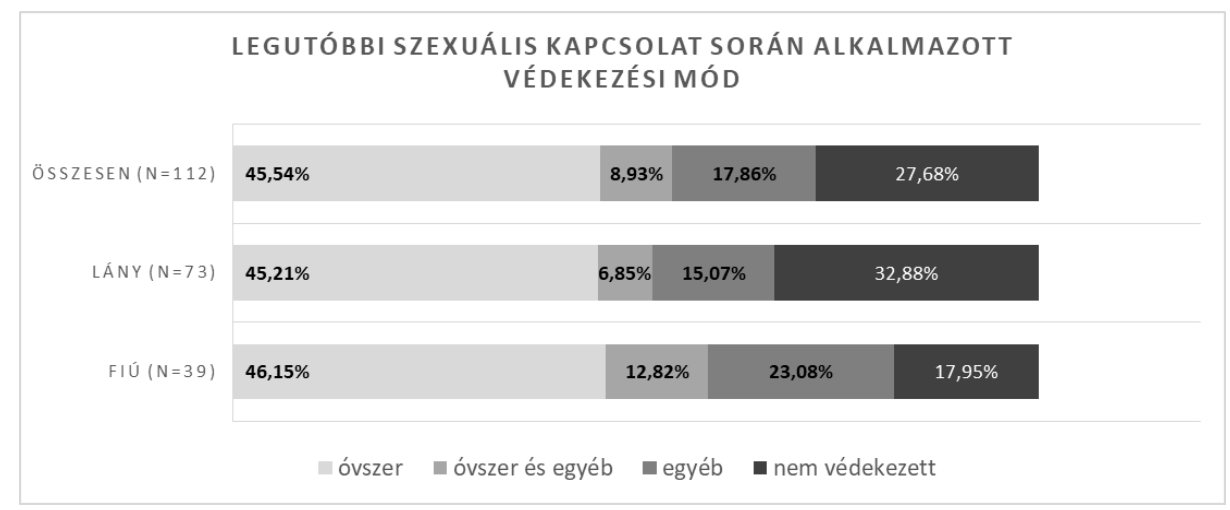

\section{Romantikus tapasztalatok}

A tanulók túlnyomó többsége 86\%-uk $(\mathrm{N}=259)$ már érzett szerelmet ellenkező nemú partner iránt és a diákok 71\%-nak $(\mathrm{N}=212)$ volt már romantikus kapcsolata is (6. ábra).
A válaszadók 56\%-a $(\mathrm{N}=)$ volt szerelmes, de nem volt kapcsolata. Hasonló arányban voltak azok a tanulók, akiknek nem volt még párkapcsolata és nem is érzett még szerelmet (7. ábra).

6. ábra: A tanulók romantikus tapasztalatai és érzései I. (forrás: a szerzőo)

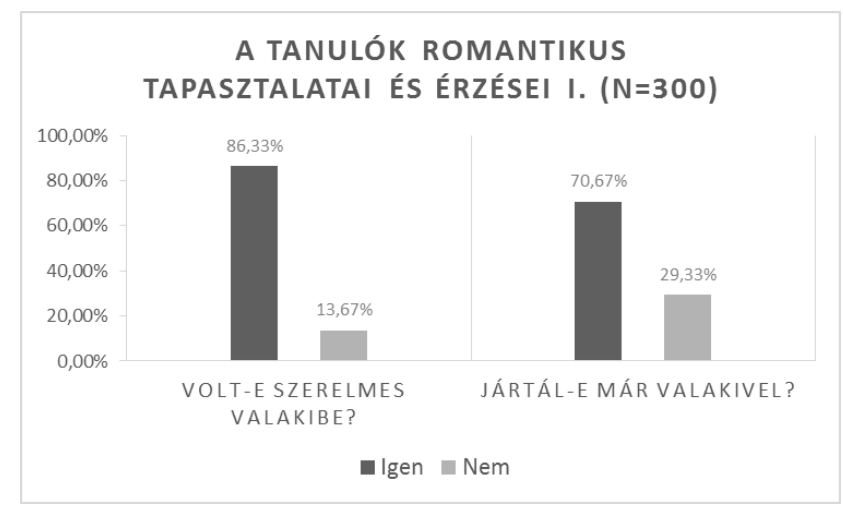


7. ábra: A tanulók romantikus tapasztalatai és érzései II. (forrás: a szerzőke)

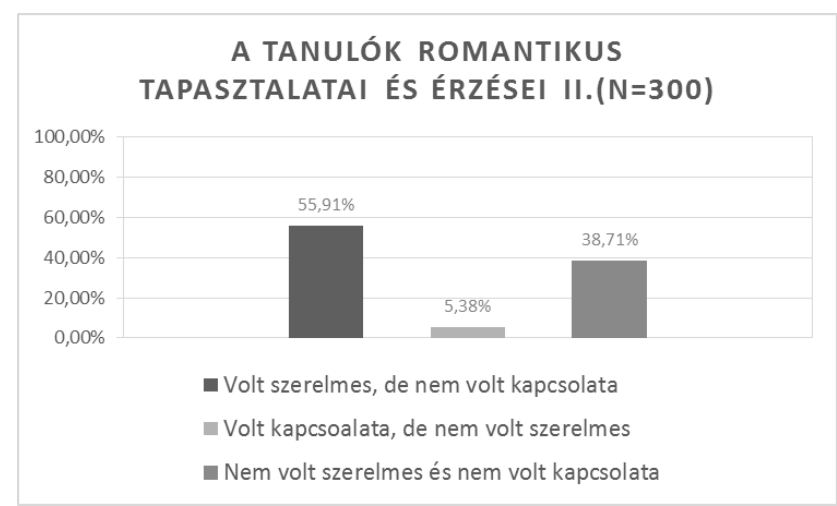

\section{MEGVITATÁS}

Az alábbiakban eredményeinket a 2014es HBSC (Iskoláskorú Gyermekek Egészségmagatartása) kutatás eredményeivel kívánjuk összevetni. A szexuális aktivitás esetében elmondható, hogy a HBSC kutatásban résztvevő magyarországi fiatalok 45\%-ának volt szexuális kapcsolata (fiúk $46 \%$; lányok 45\%). Jelen kutatásban résztvevő fiatalok esetében is közel hasonlóan alakultak az eredmények úgy a teljes mintán, mint nemek közötti bontásban. Az évfolyamok esetében mind a HBSC kutatás, mind pedig a jelen vizsgálat során megállapítható, hogy az életkor növekedésével a szexuálisan aktív tanulók száma is növekszik. Míg a 2014-ben készül felmérés során a gimnáziumi tanulók 24\%-a vallotta, hogy 14 vagy annál fiatalabb korban estek át az első szexuális aktuson, addig jelen vizsgálatban ez a szám 9\%, mely alapján elmondható, hogy a vizsgált mintában kedvezőbb a helyzet.
Mindkét vizsgálat során a tanulók által a legutóbbi aktus során alkalmazott védekezés mód az óvszer volt. Ugyanakkor a nem védekezők számának esetében különbség figyelhető meg. A hajdúszoboszlói intézmény tanulóinak 28\%-a nem védekezett a legutóbbi aktus során, ezzel szemben HBSC kutatásban résztvevő tanulók 14\%-ára igaz ez. Érdekesség, hogy a nem óvszerrel való védekezésről a vizsgálatunkban résztvevő fiatalok közül a fiúk számoltak be gyakrabban. Ezzel szemben a HBSC kutatásban résztvevő fiatalok esetében ez a lányokra volt jellemzőbb. Romantikus tapasztalat esetében nem tapasztaltunk nagyobb eltérést. Közel azonos arányban voltak szerelmesek és volt romantikus kapcsolatuk a tanulóknak (Németh és Költő, 2016).

\section{KORLÁTOZÁSOK}

A kérdőív kitöltése önkéntes és anonim volt. A végleges mintanagyságát a hiányzó 
tanulók száma befolyásolta. A kapott eredményekből nem vonhatóak le általános következtetések, csupán az adott intézmények tanulóira vonatkozhatóak az eredmények.

\section{KONKLÚZIÓK}

Összességében elmondható, hogy a vizsgált mintán magasabb azok átlagéletkora, akik már szexuálisan aktívak voltak a vizsgálat idején. Ugyanakkor még így is magasnak mondható a szexuálisan aktív tanulók száma. Az életkor előrehaladtával a vizsgálatban résztvevő tanulók esetében is nô a szexuálisan aktív tanulók száma. A legutóbbi aktus során magas az óvszert használók száma, de ezzel szemben a nem védekezők aránya jelentősnek mondható.

A vizsgálatban résztvevő tanulók igen magas százaléka volt már szerelmes és élt párkapcsolatban is. A párkapcsolatban élők többsége szerelemből volt együtt partnerével. Mindezek alapján javasolt szexuális felvilágosító programok tartása, azok esetleges módszertani fejlesztése a fiatalok szexuális magatartásának pozitív irányú változásához való bekövetkezéséhez, különös figyelmet fordítva a különféle védekezési módszerek bemutatására.

\section{IRODALOM}

Németh Á. és Költő A. (2016): Egészség és egészségmagatartás iskoláskorban. Az iskoláskorú gyermekek egészségmagatartása elne- vezésü, az. Egészségügyi Világszervezettel együttmüködésben megvalósuló nemzetközi kutatás 2014. évi felmérésról készüllt nemzeti jelentés. Nemzeti Egészségfejlesztési Intézet, Budapest.

Sedgh, G., és Finer, L., Bankole A., Eilers M. A. \& Singh, S. (2015): Adolescent pregnancy, birth and abortion rates across countries: levels and recent trend. Journal of Adolescent Health, 56, 223-230. doi: 10.1016/j.jadohealth. 2014.09.007

Rice, K. G. \& Mulkeen, P. (1995) Relationships with parents and peers: A longitudinal study of adolescent intimacy. Journal of Adolescent Research, 10, 338-357. doi: $10.1177 /$ 0743554895103003.

Erikson, E. H. (1968). Identity: Youth and crisis (No. 7). WW Norton \& Company. doi:https://doi.org/10.1002/bs.38301 $\underline{40209}$

Finer, L. B. \& Philbin, J. M. (2013). Sexual initiation, contraceptive use, and pregnancy among young adolescents. Pediatrics, 131 (5), 886891. doi: 10.1542/peds.2012-3495.

Makenzius, M., és Larsson, M. (2013). Early onset of sexual intercourse is an indicator for hazardous lifestyle and problematic life situation. Scandinavian Journal of Caring Sciences, 27 (1), 20-26. doi: https://doi.org/10.1111/j.1471$\underline{6712.2012 .00989}$ 
Jäger A. és Tigyi Z. (2012): Szexuális magatartás vizsgálat középiskolások körében. Pécsi Tudományegyetem Egészségtudományi Kar, Pécs

Rácz P. és Németh A. (2015). A fogamzásgátlással kapcsolatos ismeretek és a párkapcsolatról alkotott vélemények felmérése különbözô iskolatípusokban. Egésasségfejlesztés, 56 (1-2), 38-46.

Simich R. és Fábián R. (2010). Iskolaegészségfejlesztés-szexedukáció. Veszélyeatetett korú diákok prevenciós igényei és szǚségletei. Országos Egészségfejlesztési Intézet, Budapest. 


\title{
A PÁLYAÉRDEKLŐDÉS KAPCSOLATA A PÁLYAVÁLASZTÁSI BIZONYTALANSÁGGAL ÉS A KARRIERDÖNTÉSI ÉN-HATÉKONYSÁGGAL
}

\author{
Szerző: \\ Tudlik Csilla (Drs.) \\ Eszterházy Károly Egyetem
}

Szerző e-mail címe:

csillatudlik@gmail.com

\author{
Lektorok: \\ Mező Ferenc (PhD) \\ Eszterházy Károly Egyetem \\ Szabóné Balogh Ágota (PhD) \\ Gál Ferenc Egyetem \\ ...és további két anonim lektor
}

\begin{abstract}
Absztrakt
A pályaválasztás elvitathatatlan szereplője a pályaérdeklődés, annak vizsgálata mégis hiányt szenved hazánkban. Tanulmányunkban két kérdést vetünk fel: a pályaérdeklődés, karrier én-hatékonyság és pályaválasztási bizonytalanság tekintetében kimutatható-e különbség a nem, kor, településszerkezet és tanulmányi eredményesség tekintetében, illetve hogyan függ össze a pályaérdeklődés a hatékonyság és a bizonytalanság jelenségével. Ezek megválaszolásához pályatanácsadáson részt vevő gimnáziumi tanulók $(n=57)$ kismintás vizsgálatát végeztük el. Megállapítottuk, hogy a pályaérdeklődés esetén mutatható ki a nem, az életkor és a településszerkezet szerint különbség a tanulók között, valamint a pályaérdeklődés intenzitása nem, de egyes területei összefüggnek a pályaválasztási bizonytalansággal (negatívan) és a karrierdöntési én-hatékonysággal (pozitívan).

Kulcsszavak: pályaérdeklődés, karrier én-hatékonyság, pályaválasztási bizonytalanság

Diszciplina: pedagógia, pszichológia

Abstract

RELATIONSHIP BETWEEN CAREER INTEREST AND CAREER CHOICE UNCERTAINTY AND CAREER SELF-EFFICACY

Career interest has an undisputed role in career decision, however, its thorough examination lacks in our country. The study has raised two questions: whether any difference can be detected on interest, career self-efficacy and career indecision by gender, age, living area and academic achievement, furthermore how interest correlates with the phenomenon of career self-efficacy and indecision. To answer an examination was conducted on small sample of secondary school students $(n=57)$ who took part in career counselling. It was stated that (1) there is difference between the students' interest in terms of gender, age and living area; (2) the intensity of interest does not, but (3)
\end{abstract}


distinct part of the interest correlate with career indecision (negatively) and career selfefficacy (positively).

Keywords: career interest, career self-efficacy, career indecision

Disciplines: pedagogy, psychology

Tudlik Csilla (2020): A pályaérdeklődés kapcsolata a pályaválasztási bizonytalansággal és a karrierdöntési én-hatékonysággal. OxIPO - interdiszciplináris tudományos folyóirat, 2020/3, 43-54. doi: 10.35405/OXIPO.2020.3.43

\section{IRODALMI ÁTTEKINTÉS}

Valamennyi pályaválasztási elméletben elvitathatatlan szerepe van a pályaérdeklődésnek, mégis kevés figyelmet kap hazánkban az utóbbi időben. A pályaérdeklődés feltárása nem öncélú tevékenység, sokkal több, mint a jó iskola kiválasztása vagy a kívánatos szakmai képzés megtalálása. Újabb és újabb, akár évtizedeket átölelő kutatások is bizonyítják, hogy az érdeklődés összefügg a munkahelyi beválással, a mentális jólléttel, az elégedettséggel és a sikerérzettel (Allen és Robbins 2008, 2010, Dik és Hansen 2008).

A pályaérdeklődéssel kapcsolatban álló tényezőket többször vetették már vizsgálat alá, ilyen a nem, az életkor, a társadalmi-gazdasági státusz vagy a tanulmányi eredményesség. Ezek közül bizonyítottnak tűnik, hogy a nem egyértelmüen befolyásoló tényező, a férfiak általában a tárgyakkal, míg a nók az emberekkel foglalkoznak szívesebben.

Számos kutatás azonban kimutatta (Christensen és Knezek, 2017, Li és Liu, 2015, Ekore, 2014, Ludwickowski és tsai,
2019, Su és tsai, 2009), hogy a műszaki terület nem a férfiak privilégiuma, a nôk ugyanúgy fel tudnak zárkózni tudásban, érdeklődésben, aprólékosabbak a feladatmegoldások során, és motiváltabbak (Henderlong és Lepper, 2007, Ion, Nye és Iliescu, 2019), ha nem őket, hanem az elért teljesítményüket dicsérik.

Az életkor tekintetében az rajzolódott ki (Low és tsai, 2005, Schultz és tsai, 2017), hogy az évek előrehaladtával stabilizálódik az érdeklődés, körülbelül kora felnôttkorra válik egyértelművé, mi fontos az egyén számára a munkákat leíró tevékenységek közül. Többen kimutatták (Diemer és Ali, 2009), hogy a családi környezet, a szülők végzettsége, és a lakóhely hatással van az érdeklődésre, hiszen az a miliő, amelyben az egyén él, amit maga körül lát és tapasztal, illetve amire a szülői indíttatás sarkallja, döntő lehet.

A fent elemzett tényezők egyirányú kapcsolatban állnak a pályaérdeklődéssel, hiszen azok befolyásolják az érdeklődés kialakulását, fordítva azonban ez nem lehetséges (eltekintve attól, hogy bizonyos 
esetben az érdeklődés és az abból kiinduló pályaválasztás nyomán olyan társadalmi-gazdasági lehetőségekre tehet szert az egyén, melyben korábban nem volt része.)

Más tényezők viszont, mint a karrierdöntési én-hatékonyság, a tanulmányi eredményesség vagy a pályaválasztási bizonytalanság kölcsönösségi kapcsolatban áll a pályaérdeklődéssel. Az első két jelenséget kiterjedt kutatás tárta már fel. Azt találták (Holland, 1997, Boyle, 2007 Patrick, Care és Ainley, 2011), hogy akinek kifejezettebb az érdeklődése, annak jobb az iskolai teljesítménye, motiváltabb, célkitűzése biztosabb, de fordítva is érvényes lehet, hiszen a jó tanulmányi eredmény, a hatékonyabb kognitív képességek bizonyos érdeklődési területeket vonzhatnak.

A karrierdöntési én-hatékonyság érdeklődéssel való összefüggésének megértéséhez Lent és munkatársai (1994) alakítottak ki értelmezési keretet. Megállapították, hogy a személyes inputokon, háttértényezőkön és a tanulási tapasztalatokon keresztül az én-hatékonyság hat az érdeklődésre, vagyis az önmagába vetett hit, hogy képesnek tartja magát a célkitűzésre, tervezésre, információgyűjtésre és megvalósításra, olyan érdeklődési területek felé irányítja az egyént, amelyben ezeket a jellemzőket kiélheti.

Kevés figyelmet kapott azonban a pályaválasztási bizonytalanság és a pályaérdeklődés közötti kapcsolat feltárása. Több kutatás arra a következtetésre jutott, hogy a bizonytalanoknak kevésbé van kialakult érdeklődésük, vagyis negatív kapcsolatban állnak, akárcsak az én-hatékonysággal (Guay és munkatársai, 2003, Taylor és Betz, 1983; Betz és tsai, 1996, 1997). A jó tanulók kevésbé bizonytalanok, és az idő előrehaladtával a bizonytalanság csökken. Holland (1997) három okban határozta meg a bizonytalanságot, melyet Osipow (1999) kiegészített eggyel:

1) a személy több ellentétes érdeklődési területtel jellemezhető,

2) nincs kialakult érdeklődése,

3) túl széles az érdeklődése vagy

4) tehetségéből kifolyólag több területre alkalmas lehet.

Releváns kutatások (Creed, Prideaux, és Patton, 2006, Feldman, 2003) azt állítják, a bizonytalanság és az érdeklődés negatív viszonyban fejezhető ki, azaz minél erősebb valaki vonzalma egy szakterület iránt, annál kevésbé kell a bizonytalansággal megküzdenie.

\section{MÓDSZEREK ÉS MINTA}

Magyar tanulói mintán történtek vizsgálatok a pályaválasztási bizonytalanság (Lukács, 2012) és a karrierdöntési énhatékonyság (Török, 2016) tekintetében, jelen tanulmány célja pedig az, hogy a pályaérdeklődést is bevonja a vizsgálatok körébe, különösen az előbbi két jelenséggel kapcsolatban. Felvetéseinket a következőkben fogalmaztuk meg:

1. Különbség van a pályaválasztási bizonytalanság, a karrier én-hatékony- 
ság és a pályaérdeklődés értékeiben nem, település, életkor és tanulmányi eredmény szerint.

2. Összefüggés van a pályaérdeklődés és a nem, település, életkor és tanulmányi eredmény szerint.

3. A pályaválasztási bizonytalanság negatívan hat a pályaérdeklődésre.

4. A karrierdöntési én-hatékonyság szintje pozitívan befolyásolja a pályaérdeklődést.

Vizsgálatunkat kérdőíves módszerrel végeztük, melyet nemre, életkorra, tanulmányi eredményre és a lakhelyre vonatkozó adatokkal egészítettük ki.

A Karriertábla (ODCTE-Tudlik, 2015) nevű eszköz a középiskolás korosztály pályaérdeklődésének felmérését teszi lehetővé önértékelés segítségével. A kérdőív tizenhat - elsősorban a felsőoktatási tudományterületeket lefedő - érdeklődést azonosít a kedvelt tevékenységek, jellemző tulajdonságok és kiemelt témák kombinációja szerint:

1. Agrár, természeti erőforrások, élelmi szer,

2. Építészet, épített környezet,

3. Mûvészet, kommunikáció, technológia,

4. Üzleti adminisztráció,

5. Oktatás-képzés,

6. Pénzügyek,

7. Kormányzati adminisztráció,

8. Egészségügy,

9. Turizmus-vendéglátás,

10. Humán szolgáltatás,

11. Információtechnológia,
12. Jog, közbiztonság,

13. Gyártás,

14. Kereskedelem-marketing,

15. Matematika, mérnöki, tudományos tevékenység,

16. Logisztika.

A tanulóknak az egyes területek iránti attitűdjét egy 17 fokozatú skálán kell jelölniük.

A Pályaválasztási Bizonytalanság Skála (Chartrand et al., 1990) négy faktor (szorongás, információszükséglet, önismeret, általános bizonytalanság) segítségével tárja fel a diákra vonatkozó döntési nehézség okát. A kérdőív öt fokozatú skálát alkalmaz a válaszok rögzítésére.

A Karrierdöntési én-hatékonyság (Betz, Klein \& Taylor, 1996) kérdőív öt faktora (önbecsülés, célkitűzés, információgyűjtés, megvalósítás és tervezés) azt vizsgálja, mennyire hisz önmagában az egyén, mennyire képes elképzeléseihez erőit mozgósítani és azokat megvalósítani. A kérdőív szintén öt fokozatú skálát alkalmaz a válaszok rögzítésére.

Elővizsgálatunkat olyan gimnáziumi tanulók körében végeztük, akik pályatanácsadáson vettek részt. Leíró statisztikájukat az 1. táblázat tartalmazza.

\section{1. táblázat A minta leiró statisztikája (forrás:}

\begin{tabular}{|c|c|c|c|c|}
\hline Nem & $\begin{array}{l}10 . \\
\text { évf. }\end{array}$ & $\begin{array}{l}11 . \\
\text { évf. }\end{array}$ & $\begin{array}{l}12 . \\
\text { évf. }\end{array}$ & Össz. \\
\hline fiú & 23 & 1 & 2 & 26 \\
\hline lány & 24 & 2 & 5 & 31 \\
\hline Össz. & 47 & 3 & 7 & 57 \\
\hline
\end{tabular}


A mintában túlsúlyban voltak a tizedik évfolyamos tanulók, illetve a megyeszékhelyen élők (53\%), így csak nem tekintetében igazán kiegyensúlyozott a vizsgálatban résztvevők köre. Tanulmányi eredményük átlaga 4,37 (SD 0,663).

\section{EREDMÉNYEK}

A pályaválasztási bizonytalanság és a karrierdöntési én-hatékonyság esetében nem mutatható ki szignifikáns különbség a nem, az életkor, a településszerkezet vagy a tanulmányi eredményesség szerint. Úgy tűnik, ezek a pályaérdeklődéssel egyirányú kapcsolatban álló tényezők nem befolyásolják sem a döntésben való bizonyosságot, sem pedig azt, mennyire bízik az egyén saját magában, képességeiben, hogy meg tudja valósítani elképzeléseit. Megállapítható azonban, hogy míg a fiúk több információt szeretnének a lehetséges szakterületekről, addig a lányok általában bizonytalanabbak, szorongóbbak és több önismeretre van szükségük. Ez utóbbi a nemi szerepek konfliktusából is adódhat, vagyis ha vonzódik is a társadalom által a férfiaknak szánt szakmák iránt, kétségei vannak, hogy neki való-e, illetve amenynyiben elfogadjuk a kutatások eredményeit, miszerint a nők szívesebben választanak az emberekkel kapcsolatos tevékenységek közül, akkor a nagy választék miatt - melyre Feldman (2003) hívta fel a figyelmet - eluralkodik a bizonytalanság.

A 10. évfolyamosok szorongóbbak és rendkívül információéhesek, a tizenegye- dikeseknél önismeretigény a kifejezett, míg a végzősök általában bizonytalanabbak. Az évfolyamok én-hatékonyságára jellemző, hogy a legfiatalabbak jók a tervezésben, a tizenegyedikesek szeretnek célt kitűzni, míg a végzősök önbecsülése magasabb és információkeresésben jók. Látható tehát, hogy a minta követi az évfolyamokról alkotott képet, hiszen a tizedik az első évfolyam, amelyikre döntés hárul, tizenegyedik az átmenet, a tényleg jó döntés volt-e kérdéssel tudnak azonosulni, míg a végzősök komolyabb elhatározásokról tudnak beszámolni, illetve feltehetően jól használják a számukra fejlesztett csatornákat, mint a Felvi.hu, nyílt felsőoktatási napok vagy az Educatio kiállítás.

A községben élők körében nagy a bizonytalanság, míg a kisvárosban élőknél a legkevésbé jellemző. A legalacsonyabb énhatékonyságot a megyeszékhelyi diákok mutatják, míg a városban élők hatékonysága a legmagasabb. Feltételezhetően a bizonytalanság és a hatékonyság szintje a települések szerinti túl kevés vagy túl sok lehetőséghez való hozzáférést jelezheti.

Mintánk tanulmányi átlaga egyik jelenséget sem befolyásolta. A kitűnők a legkevésbé bizonytalanok, míg a négyes átlagúak a leginkább bizonytalanok döntésükben, talán mert ők sem a túl jó, sem pedig a túl rossz kategóriába nem érzik odatartozónak magukat. Érdekes, hogy a karrierdöntési én-hatékonyság a közepes tanulók körében mutat jellegzetességet, a hármas tanulók érzik leginkább az én- 
hatékonyságot, míg a hármas és négyes közöttiek a legkevésbé. A tanulmányi eredmény még a pályaérdeklődést sem befolyásolta. Korábbi eredményekkel már bemutattuk (Tudlik, 2019), hogy a gimnáziumi tanulók körében végzett vizsgálatunk szerint az oktatás-képzés, turizmusvendéglátás, kereskedelem-marketing a legkedveltebb terület minden nemre, évfolyamra és településre nézve. Ez a megállapítás jelen vizsgálatunkra is érvényes, illetve a közepes tanulóknál a legváltozatosabb az érdeklődés mintázata, míg a 3,5 átlaggal bíró diákok figyelmét a legkevésbé keltik fel a szakmai tevékenységek, talán az agrár terület tűnik vonzónak számukra.

Ahol szignifikáns eltérés mutatható ki a fiúk javára, az a pályaérdeklődés köre. Az agrár, az építészet, az üzleti adminisztrá- ció, a pénzügy és az informatika kevésbé fontos a lányok számára. A tizedik évfolyamosok körében nagyon népszerű a pénzügyi-gazdasági terület, ugyanakkor szerepe fokozatosabb csökken (Bonferroni teszt: 10. évf.-12. évf. $p=0,038$, $\mathrm{MD}=2,845, \mathrm{SD}=1,102)$, míg a kereskedelem-marketing igen változékony képet mutat az évfolyamok között.

Az érdeklődési területek közül a humán szolgáltatás (például szociális munka, szociál-pedagógia, pszichológia stb.) esetében mutatható ki szignifikáns eltérés a településszerkezet szerint, mivel a kisvárosban élők kedvelik ezt a tevékenységet, a városi diákok azonban a legkevésbé találják vonzónak a másokkal való foglalatosságot (Bonferroni teszt, kisvárosnagyváros, $\mathrm{p}=0,010, \mathrm{MD}=4,345, \mathrm{SD}=$ 1,305 - lásd még: 2. és 3. táblázat).

2. táblázat: varianciaanalzis szignifikáns ( $p<0,05)$ eredményei (forrás: a Sz̨erzó)

\begin{tabular}{l|l|r|l|r|r|r|r|r}
\hline Változók & SS & df & MS & F & p & ETA & ETA $^{2}$ \\
\hline K1*nem & Between group (Combined) & 28,537 & 1 & 28,537 & 4,226 &, 045 &, 267 &, 071 \\
& Within group & 371,393 & 55 & 6,753 & & & & \\
\hline K6*nem & Between group (Combined) & 53,926 & 1 & 53,926 & 7,366 &, 009 &, 344 &, 118 \\
& Within group & 402,635 & 55 & 7,321 & & & & \\
\hline K11*nem & Between group (Combined) & 88,465 & 1 & 88,465 & 7,109 &, 010 &, 338 &, 114 \\
& Within group & 684,377 & 55 & 12,443 & & & & \\
\hline K6*évfolyam & Between group (Combined) & 57,208 & 2 & 28,604 & 3,868 &, 027 &, 354 &, 125 \\
& Within group & 399,354 & 54 & 7,395 & & & & \\
\hline K14*évfolyam & Between group (Combined) & 86,115 & 2 & 43,058 & 4,337 &, 018 &, 372 &, 138 \\
& Within group & 536,095 & 54 & 9,928 & & & & \\
\hline K10*település & Between group (Combined) & 90,388 & 3 & 30,129 & 3,999 &, 012 &, 430 &, 185 \\
& Within group & 399,331 & 53 & 7,535 & & & & \\
\hline
\end{tabular}

K1: agrár; K6: pénzügyek; K10: humán szolgáltatás; K11: informatika; K14: kereskedelem-marketing 
3. táblázat: Az érdeklödési területek, a pályaválasztási bizonytalanság és a pályadöntési énhatékonyság adatainak leiró statisztikája (n=57). Forrás: a Szerzo"

\begin{tabular}{|c|c|c|c|c|}
\hline Változó & Átlag & Szórás & Minimum & Maximum \\
\hline K1: Agrár... & 6,04 & 2,672 & 1 & 14 \\
\hline K2: Építészet... & 7,23 & 3,012 & 1 & 13 \\
\hline K3: Művészet... & 6,67 & 3,043 & 2 & 14 \\
\hline K4: Üzleti adminisztráció & 7,05 & 2,552 & 2 & 13 \\
\hline K5: Oktatás-képzés & 8,93 & 2,665 & 3 & 15 \\
\hline K6: Pénzügyek & 6,25 & 2,855 & 0 & 13 \\
\hline K7: Kormányzati admin. & 7,19 & 3,091 & 2 & 15 \\
\hline K8: Egészségügy & 7,05 & 2,906 & 2 & 15 \\
\hline K9: Turizmus-vendéglátás & 8,67 & 2,984 & 3 & 16 \\
\hline K10: Humán szolgáltatás & 7,07 & 2,957 & 1 & 15 \\
\hline K11: Információtechnológia & 6,95 & 3,715 & 0 & 15 \\
\hline K12: Jog, közbiztonság & 7,88 & 3,295 & 2 & 15 \\
\hline K13: Gyártás & 5,58 & 2,891 & 0 & 13 \\
\hline K14: Kereskedelem-marketing & 8,47 & 3,333 & 2 & 14 \\
\hline K15: Matematika, mérnöki... & 5,77 & 3,196 & 1 & 13 \\
\hline K16: Logisztika & 6,74 & 2,553 & 2 & 13 \\
\hline Éh-önbecsülés & 19,12 & 2,639 & 14 & 24 \\
\hline Éh-cél & 17,82 & 2,873 & 8 & 24 \\
\hline Éh-inf. & 20,04 & 2,368 & 15 & 25 \\
\hline Éh-megoldás & 19,21 & 3,069 & 11 & 25 \\
\hline Éh-tervezés & 18,81 & 2,973 & 12 & 24 \\
\hline PV-szorongás & 18,72 & 3,745 & 11 & 26 \\
\hline PV-bizonyt. & 14,40 & 1,801 & 10 & 19 \\
\hline PV-infó & 7,35 & 1,837 & 3 & 10 \\
\hline PV-önismeret & 15,42 & 4,101 & 4 & 20 \\
\hline ÉH-össz. & 95,00 & 10,503 & 73 & 119 \\
\hline PV-össz. & 55,89 & 6,143 & 44 & 71 \\
\hline Érdeklődés össz. & 113,5263 & 31,79011 & 63,00 & 174,00 \\
\hline
\end{tabular}

Holland (1997) elgondolása szerint a pályaérdeklődés elevációja is fontos mérőszám lehet. Az egyes érdeklődési területeken elért pontszámok összességét annak kifejezésére alkalmazta, hogy az egyén általánosságban mennyire intenzív érdeklődéssel rendelkezik. Mintánkban azonban nem volt arra vonatkozó jel, hogy az érdeklődés intenzitása és a pályaválasztási bizonytalanság, valamint a karrierdöntési én-hatékonyság között összefüggés lenne. Nem tudtuk tehát azt az elképzelést bizonyítani, miszerint minél kifejezettebb öszszességében az egyén érdeklődése, vagyis sok területben, tevékenységben és témában talál magának vonzót, annál kevésbé bizonytalan és annál inkább én-hatékony pályadöntésében.

Azt azonban meg tudjuk erősíteni, hogy bizonyos érdeklődési területek összefüg- 
gésben állnak a bizonytalansággal és az én-hatékonysággal, továbbá azok mutatják a korábbi kutatások feltevéseit, vagyis a bizonytalansággal negatív, míg az énhatékonysággal pozitív a kapcsolat.

Az 1. ábrán látható, hogy egyes területeket (építészet, művészet, oktatás, kor- mányzat, humán szolgáltatás, informatika, jog, természettudományos-kutatói) nem érintett meg a bizonytalanság és az énhatékonyság szintje. Ugyanakkor e három jelenség kapcsolata egyértelműen kimutatható.

1. ábra. Az érdeklödés, a bizonytalanság és az én-hatékonyság összefüggései (n=57). Forrás: a Sžrzón

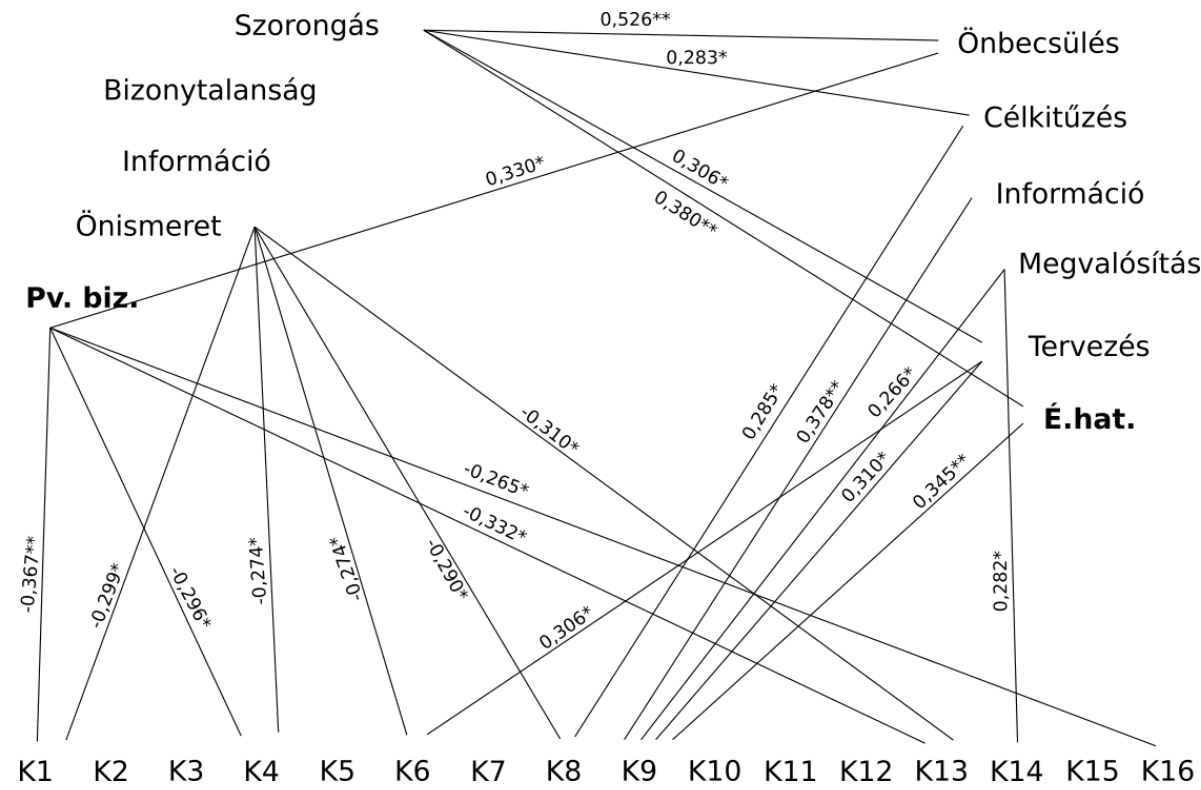

\section{Rövidítések:}

K1: agrár, K2: építészet, K3: müvészet, K4: üzleti adminisztráció, K5: oktatás, K6: pénzügy, K7: kormányzati adminisztráció, K8: egészségügy, K9: turizmus, K10: humán szolgáltatás, K11: IT, K12: jog, K13: gyártás, K14: kereskedelem-marketing, K15: matematika, mérnöki, tudományos, K16: logisztika, Pv.biz.: pályaválasztási bizonytalanság, É.hat.: én-hatékonyság 
Az érdeklődési területeknél úgy tünik, a pályaválasztási bizonytalanság és annak önismereti faktora a valódi befolyásoló tényező. Az agrár, az üzleti adminisztráció, a pénzügy, az egészségügy és a gyártást választók magas önismeretről tesznek tanúbizonyságot, vagy megfordítva, minél kevésbé ismeri önmagát, annál kevésbé választ ezen területek közül. Az összesített pályaválasztási bizonytalanság értéke hasonlóan negatív kapcsolatban áll az agrár, az üzleti adminisztráció, a gyártás és a logisztika területével. Úgy fogalmazhatnánk meg, hogy vizsgálatunk eredménye megegyezik Feldman (2003) gondolatával, miszerint a gyakorlatiasabb foglalkozások, ahol könnyen értelmezhetőek a tevékenységek, kevésbé teszik bizonytalanná a fiatalokat, míg az elméleti feladatokba nehéz beleképzelni önmagukat, ezért ott fokozódik a bizonytalanság.

Lent és munkatársai (1994) szerint az én-hatékonyság hat az érdeklődésre, s tulajdonképpen ez is igazolást nyert vizsgálatunkban. Azok a tanulók, akik hatékonyabbnak érzik magukat, illetve az énhatékonyság összetevőit könnyen alkalmazzák, leginkább az egészségügy, a vendéglátás-turizmus, a kereskedelem-marketing és a pénzügyek területéről választanak maguknak. Vagyis elsősorban olyan szakmákban gondolkodnak, ahol az emberi kapcsolatoknak, a meggyőzésnek, a segítségnyújtásnak, az irányításnak, a szervezésnek és tervezésnek egyaránt szerepe van.
A pályaválasztási bizonytalanság és a karrierdöntési én-hatékonyság jelensége két ponton találkozik. Egyrészt az látszik, hogy összességében a bizonytalanság az önbecsüléssel van összefüggésben, másrészt az én-hatékonyság a szorongáshoz kapcsolódik. Az azonban kérdéses, hogyan értelmezhető, hogy a gyakorlatias foglalkozások közül választva minél kevésbé bizonytalan az egyén, pozitív önértékelése annál kevésbé kifejezett, hiszen ez ellentmond több eddigi vizsgálatnak (Taylor és Betz, 1983; Betz és mtsai, 1996, Germeijs és Boeck, 2003, Török, 2016). Továbbá az emberekkel kapcsolatos érdeklődési területek inkább a karrierdöntési én-hatékonysággal állnak kapcsolatban, és mintánk alanyai jobban szoronganak. Feldman (2003) arra hívta fel a figyelmet, hogy a humán (és a müvészi) területek nagy változatossága és kevés konkrétuma növelheti a bizonytalanságot.

\section{GYAKORLATI MEGKÖZELÍTÉS}

Tanulmányunkban egy olyan területtel kívántunk foglalkozni, nevezetesen a pályaérdeklődéssel, amely az utóbbi évtizedekben hiányzott a kutatási palettáról. Jelentőségét nehéz lenne vitatni, hiszen valamennyi pályaválasztási elmélet és tanácsadási forma központi szerepet szán neki. Célunk volt, hogy megállapítsuk, a pályaérdeklődés a nemmel, az életkorral, a településszerkezettel vagy a tanulmányi eredményességgel mutat-e összefüggést. Továbbá célunk volt két olyan jelenséggel 
- a karrierdöntési én-hatékonysággal és pályaválasztási bizonytalansággal - összekapcsolni a pályaérdeklődést, amelyek különösen az utóbbi - bőven szolgáltatnak még vizsgálati lehetőséget.

Megállapítottuk, hogy a pályaérdeklődést mintánkban befolyásolja a nem, az életkor és a településszerkezet, ugyanakkor nincs kapcsolatban a tanulmányi eredményességgel.

A pályaérdeklődés intenzitása, vagyis hogy az egyén összességében milyen kíváncsisággal, nyitottsággal fordul a lehetséges tevékenységek felé, sem a személyes jellemzőkkel, sem a lakhellyel, sem pedig a bizonytalanság vagy én-hatékonyság jelenségével nincs összefüggésben mintánkban.

Láthatóvá vált, hogy a triád tagjai egyrészt megfelelnek az előzetesen várt eredménynek, azaz az érdeklődés a pályaválasztási bizonytalansággal negatív, míg a karrierdöntési én-hatékonysággal pozitív viszonyban áll. Másrészt azonban arra is fény derült, hogy a gyakorlatorientált érdeklődési területet választókra nem jellemző a bizonytalanság, ám önbecsülésük ezzel ellentétes irányú, míg az emberekkel kapcsolatos tevékenységeket űzők biztos én-hatékonyságot élnek át, ugyanakkor ez szorongással is eltölti őket.

A középiskolai munkára vonatkozóan úgy fogalmazhatnánk, hogy az önismeret segítése elsődleges fontosságú, az egyéni érdeklődési területek szélesítése a nem figyelembevételével elengedhetetlen, továbbá külső segítséggel a felmerülő szo- rongás kezelése hozzájárulhat az alapos pályadöntés meghozatalához.

\section{IRODALOM}

Allen, J. \& Robbins, S. (2008). Prediction of college major persistence based on vocational interests and first-year academic performance. Research in Higher Education, 49, 62-79. doi: 10.1007/s11162-007-9064-5

Allen, J. \& Robbins, S. (2010). Effects of interest-major congruence, motivation, and academic performance on timely degree attainment. Journal of Counseling Psychology, 57, 23-35. doi: $\underline{10.1037 / \mathrm{a} 0017267}$

Betz, N. E., Klein, K. L., \& Taylor, K. M. (1996). Evaluation of a short form of the Career Decision-Making SelfEfficacy Scale. Journal of Career Assessment, 4, 47-57.

Betz, N. E. \& Voyten, K. K. (1997). Efficacy and outcome expectations influence career exploration and decidedness. Career Development Quarterly, 46, 179-189.

Byole, E. J. (2007). Vocational Interest and other non-cognitive factors as predictors of academic performance in high school. MA disszertáció, University of Johannesburg

Chartrand, J. M. et al. (1990). Development and validiation of the Career Factors Inventory. Journal of Counseling Psychology, Vol. 37., No. 4., 491-501. 
Christensen, R. \& Knezek, G. (2017). Relationship of middle school student STEM interest to career intent. Journal of Education in Science, Environment and Health, 3(1), 1- 13.

Creed, P., Patton, W. \& Prideaux, L-A. (2006) Causal Relationship Between Career Indecision and Career Decision-Making Self-Efficacy: A Longitudinal Cross-Lagged Analysis. Journal of Career Development 33(1):pp. 47-65.

Diemer, A. M. \& Ali, S. R. (2009). Integrating Social Class Into Vocational Psyhology. Journal of Career Assessment 17(3):247-265, doi: $\underline{10.1177 / 1069072708330462}$

Dik, B. J. \& Hansen, J.-I. C. (2008). Following passionate interests to wellbeing. Journal of Career Assessment, 16 (1), 86-100. doi: $\underline{10.1177 /}$ 1069072707305773

Ekore, J. O. (2014). Sex Role Expectations as Predictors of Career Interests among Senior Secondary School students in Ibadan metropolis. Gender \& Behaviour, 12(3), 6211-6222.

Feldman, D. C. (2003). The antecedents and consequences of early career indecision among young adults. $\mathrm{Hu}$ man Resource Management Review, 13, 499-531.

Germeijs, V. \& Boeck, P. D. (2003). Career indecision: Three factors from decision theory. Journal of Vocational Behavior, 62, 11-25.
Guay, F., Senécal, C., Gauthier, L. \& Fernet, C. (2003). Predicting career indecision: A self- determination theory perspective. Journal of Counseling Psychology. 50(2) 165- 177. old.

Henderlong C. J. \& Lepper, M. R. (2007). The effects of person versus performance praise on children's motivation: Gender and age as moderating factors. Educational Psychology, 27(4), 487-508.

Holland, J. L. (1997). Making vocational choices: A theory of vocational personalities and work environments (3rd ed.). Odessa, FL: Psychological Assessment Resources. doi: dx.doi.org/10.1037/ a0033587

Ion, A., Nye, C. D. \& Iliescu, D. (2019). Age and gender differences in the variability of vocational interests. Journal of Career Assessment, 27(1), 97-113 doi: $10.1177 / 1069072717748646$

Lent, R.W., Brown. S.D. \& Hackett, G. (1994). Toward a unifiying social cognitive theory of career and academic interest, choice, and performance. Journal of Vocational Behavior, 42, 79-122.

Li, Yaoran \& Liu, Ruitao (2015). Students' Career Interests and Understanding about Occupations: A Study Using Whyville Players' Behavioral Data. Issue Brief ACT research and policy

Low, K. S. D., Yoon, M., Roberts, B. W. \& Rounds, J. (2005). The stability of interests from early adolescence to middle adulthood: A quantitative review of longitudinal studies. 
Psychological Bulletin, 131(5), 713-737. $\underline{10.1037 / 0033-2909.131 .5 .713}$

Ludwikowski, W. M. A., Schechinger, H. A. \& Armstrong, P. I. (2019). Are Interest Assessments Propagating Gender Differences in Occupations? Journal of Career Assessment, 1-14, doi: $\underline{10.1177 / 1069072718821600}$

Lukács É. F. (2012). A pályaválasżtás és identitásfejlödés összefüggései. A pályaválasztási bizonytalanság típusai az identitásállapotok tükrében. Doktori disszertáció, Budapest: Eötvös Loránd Tudományegyetem

Oklahoma Department of Career and Technology Education (ODCTE) (2005). Career Cluster Interest Survey

Osipow, S. H. (1999). Assessing career indecision. Journal of $V$ ocational Behavior, 55, 147-154.

Patrick, L., Care, E. \& Ainley, M. (2011). The relationship between vocational interests, self-efficacy, and achievement in the prediction of educational pathways. Journal of Career Assessment, 19(1), 61-74. doi: $\underline{10.1177 / 1069072710382615}$
Schultz, L. H., Connolly, J. J., Garrison, S. M., Leveille, M. M. \& Jackson, J. J. (2017). Vocational interests across 20 years of adulthood: Stability, change, and the role of work xperiences. Journal of Research in Personality, 71, 46-56. doi: 10.1016/i.jirp.2017.08.010

Su, R., Rounds, J. \& Armstrong, P. I. (2009). Men and things, women and people: a meta-analysis of sex differences in interests. Psychol. Bull. 135, 859-884. doi: $10.1037 / a 0017364$

Taylor, K. M. \& Betz, N. E. (1983). Applications of self-efficacy theory to understanding treatment of career indecision. Journal of $V$ ocational Behavior, 22, 63-81.

Török R. (2016). A pályadöntési énhatékonyság sajátosságai és változási mintázatai sajátos nevelési igényü és tipikus fejlödésü középiskolások körében. Doktori diszszertáció, Budapest: Eötvös Loránd Tudományegyetem

Tudlik Cs. (2019). Karriertábla a pályatanácsadásban (elóadás). XVII. Pedagógiai Értékelési Konferencia. Szegedi Tudományegyetem 


\title{
A DRÁMAPEDAGÓGIA HATÁSA A TANÁRI KOMPETENCIÁK ALAKULÁSÁRA
}

\author{
Szerző: \\ Varga-Csikász Csenge (Drs) \\ Eszterházy Károly Egyetem
}

Szerző e-mail címe:

varga.csikasz.csenge@gmail.com

\author{
Lektorok: \\ Szabóné Balogh Ágota (PhD) \\ Gál Ferenc Egyetem \\ Kovács-veréb Lilla (Drs) \\ Károli Gáspár Református Egyetem \\ ...és további két anonim lektor
}

\begin{abstract}
Absztrakt
A drámapedagógia Magyarországon már az 1970-es évektől jelen van, ez idő alatt az oktatásban betöltött szerepe sokat változott. A dráma eszközeinek fiatalokra gyakorolt személyiségfejlesztő hatásai már jól ismertek, de az általános tanárképzésben még mindig nem foglalta el méltó helyét, pedig ez a gyakorlatorientált módszer a pedagóguskompetenciákat is pozitívan formálja. A tanulmányban közölt kutatási terv a következő kérdésre fókuszál: hogyan segíthet a drámapedagógia a pedagógussá válás folyamatában?
\end{abstract}

Kulcsszavak: drámapedagógia, kutatási terv, pedagóguskutatás

Diszciplina: pedagógia

\begin{abstract}
THE EFFECT OF DRAMA PEDAGOGY ON THE DEVELOPMENT OF TEACHER COMPETENCIES

Drama pedagogy has been present in Hungary since the 1970s, during this time, its role in education has changed a lot. The personality development effects of drama tools on young people are already well known but hasn't occupied a worthy place in general teacher education yet, although this practice-oriented method also positively shapes teacher competencies. In this study a research plan focuses on the following question: how can drama pedagogy help in the process of becoming a teacher?
\end{abstract}

Keywords: drama pedagogy, project, development of pedagogue

Discipline: pedagogy

Varga-Csikász Csenge (2020): A drámapedagógia hatása a tanári kompetenciák alakulására. OxIPO - interdiszciplináris tudományos folyóirat, 2020/3, 55-72. doi: 10.35405/OXIPO.2020.3.55 
Magyarországra az 1970-es években Mezei Éva és Debreczeni Tibor külföldi tapasztalatainak köszönhetően került a drámapedagógia. A módszer gyakorlattal kapcsolatos szakértelmét Mezei Éva Birminghamből, Debreczeni Tibor pedig Prágából hazatérve osztotta meg a szakmabeliekkel, gyermekszínjátszással foglalkozókkal. Később pedagógiai kísérletekben értintetté vált a téma - Gáspár László és Zsolnay József munkásságát kiemelve , de Gabnai Katalin neve is közismertté vált a drámajátékokkal kapcsolatban.

1988-ban alakult meg a Magyar Drámapedagógiai Társaság, melynek tagjai nagy szerepet játszottak a drámapedagógiai módszerek terjesztésében, és a kilenctagú vezetőség jelenleg is - Kaposi László vezetésével - képzésekkel, szakmai napokkal, versenyekkel igyekszenek színesíteni a nevelési programok palettáját.

A drámapedagógia magyarországi történetében fontos esemény volt David Davis 1991-ben Fóton tartott kurzusa. A dráma professzorának célja a módszer hazai önállósodásának elősegítése volt.

A témában ma, Cziboly Ádámmal együtt is kutató Bethlenfalvy Ádám írására hivatkozva, az angol drámapedagógia történetéből több úttörő nevét szükséges kiemelnünk: Peter Slade, Gavin Bolton és Jonothan Neelands személye mellett persze Dorothy Heathcote munkásságának említése is elengedhetetlen az angol drámapedagógiában (Bethlenfaly, 2005). Az angolszász dráma kapcsán két kategória, a
Drama in Education (DIE) és a Theatre in Education (TIE) ismert.

A DIE célja: problémák drámán keresztüli megértése; a második a színházról való tanulás. A tanítási dráma Dorothy Heathcote nevéhez kötődik, követői is rá hivatkoznak a fogalmat használva, de Gavin Bolton volt, aki osztályozta dramatikus tevékenységformákat. A felosztásban a tanítási - vagy az úgynevezett „komplex” dráma - volt a „D” típus. Ez utóbbi terjed el a magyar drámapedagógusok körében is. A komplex drámában a játszók egy „mintha” világba kerülnek. Erről Jonothan Neelands (2013, 8. o.) így ír:

- „Úgy cselekszem »mintha« valaki más lennék.

- Úgy cselekszem »mintha« ebben a helyzetben lennék.

- Úgy cselekszem »mintha« ez a tárgy valami más lenne."

Az résztvevők közösen élik meg az adott témán belül feldolgozni kívánt problémát.

A második típus, a TIE napjainkban egyre inkább kikerülni látszik az angol oktatásból: az úgynevezett ,soft skills”-ek helyére egyre inkább a megélhetést szolgáló tárgyak kerülnek be az iskolákba. (Bethlenfalvy, 2017). A Magyar Drámapedagógiai Társaság által 1993 óta minden évben két alkalommal hirdetik meg a 120 órás akkreditált drámapedagógus képzést, melyben kiemelt szerepet kap a tanítási 
dráma, a kurzus sikeres teljesítését egy ilyen foglalkozás megtartásához kötik.

A drámapedagógia útjának egy részébe beletekintve jogosan érezhetnénk, hogy mára már a magyar oktatásban és nevelésben sikeresen meghonosodott. A drámával foglalkozó szakemberek hisznek a módszer hatásosságában, napi szinten tapasztalják annak eredményességét, de a gyökeres változáshoz, áttöréshez a drámapedagógia általános tanárképzésbe történő bevezetése lenne szükséges.

Az iskolákban, az általános gyakorlatban még mindig nem vált gyakorlatiassá a módszer használata. Szabó Zsófia 2015ben végzett kutatása kimutatta, hogy a drámás képzettségű oktatók töredéke használja tantárgyi keretek között a szaktudását (Szabó, 2016).

A módszer aktualitása, használhatósága az oktatásban (személyiségfejlesztés, kapcsolatteremtés elősegítése) kiemelendő. Az Y generációnak az első nemzedék, amely gyermekkorától kezdve találkozhatott olyan elektronikai eszközökkel, és a világhálón való időtöltéssel, ami a mindennapi tevékenységeink, munkáink részévé váltak (Szőke-Milinte, 2019). Ezért szükséges az iskola rendszerén keresztül a lexikai tudás megszerzése mellett - a drámapedagógiát, és a hozzá hasonló módszereket tudatosan beépíteni a diákok hétköznapjaiba.

Az újabb generációkat tanító szakemberek képzése már diákkorban is elkezdődik, hiszen a pedagógussá válás folyamata nem az egyetemre lépéssel indul el. A tanári pályára lépést elősegítik azok a tapasztalatok, amit diákként az osztálytársak vagy kisebbek tanításában átélünk, vezetői feladatokban vállalunk, színpadhoz való kiállásunkban, előadásunkban vagy más múvészeti tevékenységben megtapasztalunk (Dudás, 1984, 2013, Komlósi, Dudás és Vastagh, 1987).

\section{A DRÁMAPEDAGÓGIA ALAKULÁSA MAGYAR- ORSZÁGON}

Az 1973-ban Mezei Évának és Debreczeni Tibornak a Pécsen megrendezett Országos Diákszínjátszó Fesztivál nyújtott lehetőséget arra, hogy a szakmabelieknek és a nagyközönségnek is átadhassák a külföldön szerzett ismereteiket. Ezen az alkalmon számolnak be először a fentebb említett birminghami és prágai tapasztalatokról. Mindketten látták, hogy a gyermekszínjátszás mellett az iskolai oktatásban is alkalmazható lenne a drámapedagógia nyújtotta eszköztár. De ezt megelőzően először a gyermek- és diákaszínjátszó közösségek gyakorlatába és a játszóházi tevékenységekbe emelték át a módszer elemeit. Mezei és Debreczeni is a hétköznapi oktatás megújítását látta a tanintézményekben való beemelés gondolatában (Tölgyessy, 2011). A drámapedagógia több az egyszerű utánzásnál, mely „során a jelentésnek mindössze egyetlen dimenzióját adja: a denotatív vagy tárgyi jelentést. Ahhoz, hogy a cselekvés drámai erővel bírjon, más jelentéstartalmaknak 
kell előtérbe kerülniük. (A drámatanmenetek többsége sajnos erőteljesen épít az utánzásra ezen belül pedig nem ritkán az érzelmek imitációját várja el!) Ezt pedig két egymással szembeállítható tényező határozza meg: a személyes, egyedi és az általános érvényü jelentés." (Bolton, 1996, 2. o.). A ma drámát oktatók, tanítási drámát használó pedagógusok ezen felismeréseknek és oktatási anyagok létrehozásának hála, olyan alapvető ismeretekkel, fogalomtárral rendelkezhetnek, amivel korábban nem.

A dráma egyik ilyen technikai fogásáról, a konvenciókról, Dorothy Heathcote a következőképpen ír: „A konvenciók (...) speciális módokon aknázzák ki a jel és jelentés viszonyát: legtöbbjük megváltoztatja a szereppel való kapcsolatteremtés és a »közvetlen idő« (immediate time) működésének módját, (...) lelassítja az időt, valamint saját gondolkodásuk és a döntések feletti hatalomhoz juttatja az osztályokat." (Heathcote, 2013, 123. o.). A drámapedagógia iskolák falain belüli terjeszkedéséhez Zsolnai József 1971-es nyelvi, irodalmi és kommunikációs programja is hozzájárult, azzal hogy a program tervezetébe bekerültek a dramatikus eljárások is (Eck, 2015). A már említett drámapedagógus, Gabnai Katalin, aki - bár Mezezinél és Debreczeninél fiatalabb - a módszer honosítóinak oszlopos tagja, ma is élharcosa a drámapedagógia küzdelmeinek. Többször megfogalmazta munkássága során a szakos tanárképzés szükségességét, de számtalan elutasítást kapott az ötlete. Egy 2019-es szakmai előadáson idézték egy levelének szavait, amiben úgy fogalmazott, hogy amíg a drámapedagógiai nincs az általános tanári és nevelési képzésben, addig a törekvések csak önálló „partizánakciók”. (Kinyílt az aranykapu? Színházi nevelés és a rendszerváltás, 2019). A drámapedagógia követelményrendszerének kidolgozásában is részt vállalt, mely munka a dramatikus nevelési program 1972-1982-ig néven található meg (Papp és Trencsényi, 1984). Végül a '90-es években a Színházés Filmművészeti Egyetemen elindulnak a szakirányú továbbképzések, melyekben Gabnai Katalin vezető szerepet játszik. Így alakult meg az első drámapedagógiai képzés, ami mellett 1993-ban Zsámbékon is kezdetét veszi egy kurzus, Gabnai és Móka János szervezésében.

1995-ben - amikor a Nemzeti Alaptantervbe is bekerül a mûvészetek műveltségterület - az iskolák is tárt kapukkal várják a tánc és dráma néven ismerté vált tárgyat (Tölgyessy, 2011).

2003-ban a dráma és tánc névre módosult műveltség(rész)te-rület óraszámai nem erősödtek tovább, pedig hogy „mára a tartalmi szabályozók tekintetében szinte a többivel teljesen egyenrangú tantárgy lett a Dráma és tánc, létezik dráma érettségi, OKTV, felmenő rendszerű művészeti versenyek, kiépültek a színjátékos alapfokú múvészeti iskolák és léteznek egyetemi képzések, sőt formálódóban van egy akadémiai bizottság is a témában" (Kaposi, 2015, 2. o.). 
A tantárgy a 2000-es évektől önálló óraszámmal van jelen az 5-6. és gimnáziumi 9-10. osztályban. A helyi tantervben és gyakorlatban a tárgyon belüli részterületek (dráma, népi kultúra, bábjáték, néptánc) megismerésére kéthetente egy óra adott. Visszalépés volt a 2010-es év a dráma és tánc érettségi vizsgát illetően, ugyanis 2005-től kétszintű-, 2010 őszétől középszintű vizsga tehetô le a tárgyból. (Tölgyessy, 2011).

A dráma fejlődése, iskolába és felsőoktatásba való bekerülése ellenére a szakmabeliek folyamatos küzdelmekről adnak tájékoztatást. A bevezetőben már említett kutatás (Szabó, 2016) amellett, hogy bemutatta az olyan drámás végzettségűek számát, akik tantárgyi keretek között is használják drámás szaktudásukat, más információkkal is szolgál. Az általános- és középiskolai drámaoktatásban milyen arányban találhatóak meg a drámás végzettségű pedagógusok. A statisztikai adatok a különböző megyék közti különbségeket is jól kimutatják - melyben Pest megye kiemelkedő mint kulturális központ -, drámatanításban például BorsodAbaúj-Zemplén és Jász-Nagykun-Szolnok jó adatokat mutat a nagyobb népsűrűségű és területű megyék melletti hátrányban is. Tolna, Baranya, Heves és Nógrád megyében kevesebb aktivitást vélhetünk felfedezni.

Az elektronikai eszközök megjelenésével az iskolai tevékenységformák is kezdtet átalakulni, és talán napjainkban, 2020ban egy világjárvány betoppanásával és az online oktatásba való kényszerüléssel nem kell bemutatni, hogy milyen digitális alternatívákat használhatunk a tanulás és tanítás érdekében Az online funkciókkal élve személyes kapcsolataink, a jelen világban való létezésünk is átalakult: bármikor bárhol elérhetővé vált az ember, a tanár, a diák és a tananyag is. Az világhálón a drámapedagógiai tevékenységek is megállják a helyüket, megalakult a Dráma akciócsoport, melynek célja „hogy keressük, kutassuk, felfedezzük a drámapedagógia alkalmazási lehetőségeit a tantermen kívüli digitális munkarendben. Hiszünk abban, hogy ez a nem vágyott helyzet mindanynyiunk számára lehetőség is, amelyben megmutathatjuk a drámapedagógia erejét és a drámapedagógusok kreativitását, amely nem ismer lehetetlent, és amelynek az online tér sem szabhat gátat" (Magyar Drámapedagógiai Társaság, 2020).

Ha általánosságban beszélünk az internethasználatról, annak az ifjú generációkra gyakorolt pozitív és negatív oldalait is látnunk kell, hiszen nem zárkózhatunk el a fejlődés eme formájától sem (már nem is tudunk): az elektronikai eszközök tudatosan történő használata tanulható és tanulandó feladatunk. Az X generáció idejében a munka területén már használatosak voltak az elektronikai eszközök, de az Y generáció az első olyan nemzedék, akik életét gyermekkortól fogva a „digitális kütyük" és a világhálón való időtöltés szövi és formálja át (Szőke-Milinte, 2019). A ,digitális detox” kifejezése nem sokkal az okostelefonok megjelenését követően 
jelent meg. A fogalmat Catherine Price azonos címú könyve alapján ismerhetjük, amely információval szolgálhat azoknak, akiknek a valódi élmények megélése, befogadása a telefonja nélkül már nehézséget okoz. „A digitális nemzedék gyűjtőfogalom. Vonatkozik mindazokra a generációkra, akik igen korai életszakaszban találkoztak a digitális technológiával, és igen korai életszakaszban annak felhasználóivá is váltak, tehát alapjában határozta meg a szocializációjukat a digitalizáció. Leginkább az Y, Z és az alfa generációkról beszélünk, amikor a digitális nemzedéket említjük.” (Szőke-Milinte 2019, 131. o.). Az oktatási reformok gondolata e két generációt, a $Z$ és az alfa nemzedéket érinti leginkább. A közösségi kapcsolatok kialakítása, megtartása és folyamatos ápolása kiemelten fontos az emberi életben - ennek hiányát napjainkban is átélhetjük. Amellett, hogy megtanuljuk, megtanítjuk hogyan töltsük el helyesen az időnket az online felületeken, arányosan fontossá válik annak az átadása, hogyan töltsük fel minőségi idővel, valódi értékekkel személyes kapcsolatainkat.

A XX. században reformpedagógiák nevelési elveiben megjelent az a gondolat, hogy a pedagógiai tevékenységeket a szocializációs elvárásokkal összhangba állítsák. Nem lehet meglepő tehát a felvetés a XXI. században sem, miszerint a nevelési módszereket a társadalmi igényekkel összhangba kell állítani. „Azok a gondolatok, melyekből a drámapedagógia szemléletmódja táplálkozik, nem újkeletűek. Már az ókori Görögországban jellemző volt az »akadémia« (kiemelkedett ezek közül Platón iskolája), ahol a híres filozófus természeti környezetben beszélgetett, vitatkozott a köréje sereglett fiatalokkal." (Pukánszky és Németh, 1996, 53. o.). Hasonló hatással lehetett „Nietzsche életfilozófiája, Spencer pozitivista etikai nevelésfelfogása, Darwin fejlődéselmélete, Galton genetikai kutatásai, Owen gyermeki jogokról vallott véleménye, Malthus népességelmélete, ill. a korszak szociális- ifjúsági és emancipációs nőmozgalmainak jellegzetes gondolatai” a reformpedagógiai áramlatok iskolamodelljeire, mint a globális technikai változások jelenünkre (Pinczésné, 2003. 9. o.). A reformpedagógiák hagyományos pedagógus-diák kapcsolatot megbontó törekvései saját korukban ugyanolyan elképzelhetetlenek voltak, mint pár évtizeddel ezelőtt az, hogy országokat áthidalva, a képernyőn keresztül, telefon és laptop segítségével tanuljunk nyelveket egymástól több száz, vagy ezer kilométerre. A lehetőségek végtelenek, de ezek erdejében mennyire tudjuk megőrizni a személyes jelenlétet?

A reformpedagógiák többsége a harmóniára, a közösségi lét és a gyermek személyiségének egységére, az egyensúly megtalálására fókuszál. S. Lorain Hull $S_{z i^{-}}$ nésżmesterség mindenkinek című könyvében Lee Strasberg módszeréről ír, aki Sztanyiszlavszkij technikáit tovább fejlesztve olyan gyakorlatokat hozott létre, melyek segítségével megtanulhatjuk, hogyan bánjunk az érzelmeinkkel. A gyakorlatokat 
ajánlják személyiségfejlesztő csoportoknak, drámakurzusok résztvevőinek, drámát oktatóknak is. A drámatanárok által közvetített gondolatokat már Maria Montessori pedagógiai metodikájában is fellelhetjük: „A gyerekek képesek figyelemmegosztásra, reakció idejük gyorsabb, de nehezebben összpontosítanak, és csak intenzív ingerekre reagálnak. Hagyományos módszertannal nehéz kiváltani motivációt. (...) Jó, ha mozoghatnak, kommunikálhatnak egymással.” (Eck, 2015, 5. o.). A XXI. században - IKT eszközök, a teljesítményorientált nevelési elvek és fel-fel törekvő alternatív pedagógiák között - is fontos, hogy megtaláljuk az oktatási módszerek hálózatában az arany középutat.

\section{A PEDAGÓgUSSÁ VÁLÁS FOLYAMATA A DRÁMA- PEDAGÓGIA TÜKRÉBEN}

„Tudjuk, hogy a gyerekek tanulása jórészt játékban valósul meg. A mai közgondolkodás ettől eltér. Kritikusai szerint iskoláinkat még mindig herbarti terek uralják. Gyermekeinket 6 éves kortól kényszerítjük iskolapadba, legalább tíz évig napi 6-7 órában zárjuk őket a tanterem, a szűk tér rabságába.” (Eck, 2015, 5. o.). Talán maga az a teljesítményorientált világnézet is közre játszik abban, ami napjainkban az oktatásban is problémaként merül fel - mind a felsőoktatási, mind a közép- és általános iskolai tananyagbeli terheltséget illetően. Ha nem is értünk egyet azzal, hogy korábban kevesebbet kellett volna tanulnia bárkinek, a Z és alfa generáció befogadóképessége megváltozott.

A drámapedagógia elterjedtségének, használhatóságának kérdése - ezen tények függvényében - joggal merül fel az azt alkalmazó szakemberekben: nagy szükség van arra, hogy az iskolában olyan ventilálási, stresszlevezetési lehetőségeket kínálhassunk fel az újabb generációnak, amikben fel tudják oldani azt a rengeteg (például vizuális) ingert, ami percről percre éri őket a média (köztük: okostelefonok, órástévék, utcai kivetítők) hatásának tömkelege által is. Lehet, hogy - mindezen impresszióknak is köszönhetően - most jött el az ideje annak, hogy a drámapedagógia kiteljesedjen, hiszen szükség van az emberi kapcsolatépítő, közösségformáló és személyiségformáló erejére. Ehhez viszont olyan pedagógusokra lenne szükség, akik alkalmazzák és terjesztik ezt a módszert, újabb és újabb drámás gyakorlatokat ismerő, önazonos utánpótlást nevelve ezzel.

\section{A SZEREPRŐL ÁLTALÁNOSSÁGBAN}

„Az a kép, amely a leginkább tükrözi a tanításról alkotott nézeteimet, a következő: az iskola egy színház, és ebben a színházban a tanár a dramaturg, következésképpen ő dönti el, hogyan alkalmaz a színpadra valamit, hogy abból előadás lehessen. A tanulók statiszták, akik a tanulással igazi színészekké válhatnak." (Dudás, 2013, 65. o.). A drámapedagógia és a színházi nevelés eszköztárát vizsgálva 
tudhatjuk, hogy a módszer az érzelmi intelligencia, a helyes erkölcsi magatartás és a személyiség fejlesztésére is pozitiv hatást gyakorol. A fiatalok formálása mellett a technikát alkalmazó pedagógusokat is optimizmussal tölti fel.

A tanár- és diákszerepekbe - ugyanúgy, mint más szociális szerepeinkbe is - belenövünk, beleszületünk. Az, hogy milyen szerepeket vállalunk a világ színpadán, nem mindig megválasztható. A szerencsésebbek saját életükben a föszerepet játszhatják, és a darabjuk rendezői állását is betöltve ezzel önmagukat vállalják fel. Adódnak olyan életszerepek, amik örökre szólnak, nem tudunk kilépni belőlük. Amikor valaki szülővé válik, akkor megváltoztathatatlanul szülő lesz. „Mit jelent apának, főnöknek, beosztottnak, mit jelent kamasznak, s mit jelent gyereknek lenni?" - teszi fel a kérdést Gabnai Katalin drámapedagógus (Gabnai, 1999, 181. o.). Az iskolába lépve 6-7 évesen azt viszszük magunkkal, amit otthonról kaptunk, a drámajátékok során pedig ugyanezzel a csomaggal dolgozhatunk. A szerepben való játék arra is lehetőséget ad, hogy megjelenítsük a legjobb diákot, miközben a legrosszabbnak érezzük magunkat, s ezért talán mások is annak tartanak. $\mathrm{Ha}$ jól alakítunk, a szerepből kilépve is megélhetjük az ott tapasztalt pozitívumokat: az iskolapadban újra eszünkbe juthatnak jó tanuló személyiségvonásai, és a valóságban is megpróbálhatjuk átélni azt. Szerepben a szegény lehet gazdag, a gazdag pedig szegény - szembesülhetünk az anyagiaktól független barátságokkal és értékekkel, vagy éppen a pénz okozta elszigeteltséggel.

A drámapedagógia és a színházi nevelés eszközei ilyen „mintha” helyzetet teremtve lehetőséget adnak olyan dolgok utánzására, amikkel már találkoztunk, és olyanokra is, amikkel még nem, vagy nem is fogunk másképp - ezek megjelenítésének csak a fantázia szabhat határt. Önmagunkat más perspektívából ismerhetjük meg, újragondolhatunk bizonyos helyzeteket, szerepeket cserélhetünk, hogy megértsünk és megoldjunk konfliktusokat. „Bevallott célunk tehát a szociális szerepviselkedés készségtárának, kelléktárának fejlesztése is." (Gabnai, 1999, 181. o.). Amikor egy pedagógus amellett dönt, hogy a dráma eszközeit használja - akár konfliktusmegoldás, akár beszédfejlesztés, akár egy tananyag megértése a célja vele - lehetőséget ad, arra, hogy a kreativitásra, és ezzel együtt a gyermek személyiségére kerüljön a fókusz - így segítve elő a jövőbeli társadalmi és szociális szerepvállalását is (Varga-Csikász, 2018).

\section{A TANÁRI SZEREP ÉS A DRÁMAPEDAGÓGIA}

Az emberi életben a minták, és azok követése vagy elhagyása kifejezetten jelentőségteljes, főleg azokban az időszakokban, amikor változáson megyünk keresztül. Ezek a szakaszok a pedagógussá válás folyamatában is megjelennek, és nemcsak akkor, amikor már valaki betöltötte ezt a 
munkakört - jóval előbbi élményeket kell keresnünk. „Minden kezdet nehéz mondja a magyar és a német egyaránt. És valóban: a pedagógussá válás folyamatában minden egyes szakasz újabb kihívásokat, nehézségeket és lehetőségeket jelent. A német szakirodalomban nemcsak a pedagógussá válás folyamatának három szakasza, a hallgatói, a gyakornoki és a tanári szakasz kap különös hangsúlyt. Egyre többen kutatják ezen szakaszok kezdetét is, amire a német nyelvben külön szó van: az elkezdés időszaka” (Bikics, 2013).

Sok pedagógusjelölt a tanári gyakorlatának megkezdése pillanatában ismeri fel azt - és remélhetően felismeri -, hogy a korábbi tanárszerepek, amelyek példaként jelentek meg a diákéveiben, és a saját szerepvállalásaik milyen befolyással lehetnek tanári megnyilvánulásaikra. A pedagógussá válás folyamata már elkezdődhetett „a korábbi kortárscsoportokban vállalt vezetői feladatok, az osztálytársak és/vagy kisebb gyerekek tanítása, színpadhoz kapcsolódó múvészeti csoportokban végzett tevékenységgel (...). Az ilyen háttérrel rendelkező tanárjelöltek eredményesebben oldották meg a kapcsolatteremtési, kommunikációs képességek múködését igénylő feladatokat (Dudás, 1984; Komlósi, T. Dudás, Vastagh, 1987)." (Dudás, 2013). A személyes és iskolai élmény tehát már azelőtt formálja a pedagóguspályára lépő hallgatót, mielőtt még a hivatás iránti elköteleződés csírája napfényhez és vízhez juthatna. Ebből látható, hogy a gyermeknek, mint a jövő pedagó- gusának, hogyan válik hasznává az a szerepskála, amiben a drámapedagógiai tevékenységben kipróbálhatná magát.

A hallgatók más és más tudásanyaggal érkeznek az egyetemekre, hiszen különböző iskolákban, különböző mintákat sajátítottak el. Az egységesen meghatározott tudásanyag, amivel közel tizenkét évig foglalkoznak, az érettségi vizsga sikeressége nem jelentik azt, hogy az iskolák ahogy az egyetemek sem - képesek a diákokat úgy az egyetemre küldeni, hogy az általános műveltség és ismeretanyag minden részterülete lefedve legyen. „A pedagógusok alapképzése, legyen az bármenynyire is jó minőségű, tanulási eredményekre irányuló, és nem képes a gyakorlat minden részterületét sikeresen ellátni képes pedagógusokat kibocsátani. A szaktárgyi és a pedagógusmesterségbeli felkészítés terjedelme olyan mértékben bővült, hogy mindez nem szorítható be az alapképzés keretei közé. Az egyes iskolák, területek közötti eltérések sajátos kompetenciákat igényelnek, amelyre a speciális felkészítés csak a munkahely ismeretében, továbbképzési formában oldható meg." (Falus, 2013, 22. o.). A pedagógusok körében a sikeresség érdekében kiemelendő az élethosszig tartó tanulás kulcsszerepe is.

Az általános iskolás korosztályt szemlélve már hat-hét éveseknél megfigyelhető például néptánc próbákon, fellépéseken, zenei tanulmányokban és iskolai versmondó versenyeken a megkövetelt színpadi fegyelem: tehát az ember korához és 
tevékenységéhez illő, számonkérhető előadói magatartás. A fegyelmezettség kifejezésének használata jelentőséggel bír, tudnillik a nyilvánosság előtti előadás- és megjelenésmód, kiállás, beszédtechnikai gyakorlottság már az óvodai szocializációs, kulturális tevékenységekben is ismert különböző ünnepek közös megélésének alkalmával. Ezek a szereplési lehetőségek az oktatási intézmények különböző projektnapok szervezésében is megjelenik, például a műsorra való készülődés munkafolyamatában, beleértve az óvodákban a szülő-gyermek- pedagógus kapcsolatának közös tevékenységét is. Ez az életre, élethelyzetekre nevelés folyamata: „A múvészi tevékenység mind a mai napig megőrizte beavatás jellegét: a műalkotások által közvetített sors- és magatartásminták megismerése az egyén szocializációjának döntő mozzanata, a kulturális közösség fennmaradásának biztosítéka." (110/2012. Korm. rendelet, 10784. o.). A drámapedagógia mint művészi tevékenység, segítséget nyújthat az egyetemi éveit, a gyakornoki idejét vagy az első munkanapját kezdő pedagógusjelöltnek, tanárnak is. A drámás módszertan lehetőséget nyújt a pedagógus pályára készülők személyiségének fejlesztésére is, elvégre a tanítási gyakorlatok ideje alatt gyakran kerül a tanárszakos hallgató abba a kettős szerepe, hogy a nap egyik felében diák, a másikban pedig tanárként kell helytállnia. Egyszerre ülnek még az egyetem padjaiban, és kezdenek oktatni a gyakorló iskolákban. Ezzel párhuzamosan jelenik meg a szerepváltás, a szerepbizonytalanság problémája is. (Bikics, 2013). A szakmai tudás gyakorlatba való átültetése, az osztályok előtti megszólalás okozta stressz, és a mentor előtti megfelelni akarás vágya túl sok figyelemmegosztást igényel ilyenkor a gyakorló pedagógustól.

A dráma eszköztára ,szinte nélkülözhetetlen a személyiségfejlesztésben, a pedagógus alkalmasság érdekében. A drámás készség- és képességfejlesztés, kommunikációs tréningek, helyzetgyakorlatok, szituációs játékok a tanári kompetenciafejlesztés talán leghasznosabb eszközei lehetnének. Emellett igen fontos alkalmazása a szakmódszertani fejlesztésben (pl.: hospitálások drámaórákon és drámás módszertannal dolgozó nem-drámaórákon, előadások, workshopok, meghatározott tantárgyi célú foglalkozások stb.). Maguk a hallgatók, a tanítási gyakorlatukat végző tanárjelöltek fogalmazzák meg a legpontosabban, milyen sokat segítenek ezek a tevékenységek személyes módszertanuk kialakításában.” (Eck, 2016, 111. o.). A tanári szerepbe lépés a drámapedagógia segítségével már a gyakorlatot megelőzően is létrejöhet, és nem a mikrotanításokhoz hasonló környezetben, sőt az ott történő megmérettetéseket is előkészítve. Amíg a mikrotanítások alkalmával a pedagógusjelölt már saját tanári megnyilvánulásait ízlelgeti a hallgatótársak körében, addig egy kezdő drámás csoportban különböző tanári szerepeket ölthet magára. Ezt megteheti úgy, hogy közben nem önmagát kell játszania, hanem egy- 
egy tanártípust, szerepet, mely segíthet abban is, hogy elkezdje kialakítani saját pedagógiáját.

A végzett pedagógusok körében megjelenő korai pályaelhagyások egyik oka lehet az ún. „start-sokk”. A kifejezést a Bielefeldi Egyetemen végzett kutatásban résztvevők fogalmazták meg a különböző intézményekbe, élethelyzetekbe történő átlépésekkel kapcsolatban végzett vizsgálatuk során. A „start-sokk” arra az átmeneti állapotra utal, amit az iskolából az egyetemre, az egyetemről a munkaerôpiacra való átlépés okoz. A kezdő, végzős és már végzett hallgatók körében végzett kutatásban arra jutottak, hogy az ún. „startsokk" mind a két (iskola-egyetem, egyetem-munkaerőpiac) átlépés esetében érezhető. Az is vizsgálták a projektben, hogy milyen képességeket kellene fejleszteni, hogy ezen az átmeneti állapoton sikeresen túl lehessen jutni. Ezek a rugalmasság, alkalmazkodó- rendszerező és problémamegoldó képesség, felelősségvállalás, kockázatvállalás és önérvényesítés. (Bikics, 2013). A kutatásban elemzett terület azt s mutatja, hogy a szakmai fejlődés folyamatos, de élethelyzethez mérten változatos.

A Magyarországon szakmai gyakorlatukat teljesítő hallgatók, vagy pályakezdő éveiket kezdő pedagógusok - ha már csak Budapestre és környékére gondolunk olyan iskolába is betérhetnek, és olyan diákokkal is találkozhatnak, akik az élet valamilyen területén, de főként a szociális pilléren sérültek. Többen ezek közül a ta- nulók közül nem rendelkeznek olyan mintákkal, tanulási és életvezetési módszerekkel, amik a mindennapi nehézségekben segíthetnének nekik. Az a belső elszigeteltség, amit az említett ingerek ellen építünk, nem biztos, hogy egyedül lerombolhatók. Nélkülözhetetlen az, hogy az oktatási intézményekben dolgozók rendelkezzenek olyan tudással, tapasztalattal és gyakorlattal, amivel - egy bizonyos szakmai szintig - segíteni tudják a felnövekvő nemzedéket. A dráma lehet egy prevenciós eszköz is, amivel a kapcsolatok, a segítségadás felé nyitjuk ki a kapunkat (VargaCsikász, 2018).

Felmerül a kérdés azonban, hogy a drámapedagógiának milyen személyiségfejlesztő, motiváló hatásai lehetnek a pályakezdő és már kisebb tapasztalattal rendelkezdő pedagógusok munkájára, életére, és ezt hogyan lehetne vizsgálni. Az oktatás körforgásába ugyanis csak általuk kerülhet be a módszer sokszínúsége.

\section{A DRÁMAPEDAGÓGIA PEDAGÓGUST FEJLESZTŐ HATÁSA}

„A jó drámatanár olvasott, és nemcsak szakmailag az (drámakönyvek, újságok és cikkek iránt érdeklődve), hanem építhet a jó irodalom széles körű ismeretére. Ez utóbbiba - saját kedvencei mellett - bele kell, hogy tartozzanak a gyermek- és ifjúsági regények, novellák, a mítoszok, legendák, tündér- és népmesék, mindenfajta vallás »bibliai« történetei, s az emberiség 
története, pozitív és negatív hőseivel együtt. Az is fontos, hogy ismerje a kortárs irodalmat, a tévé- és mozifilmeket, újságokat, képregényeket olvasson, kiállításokat nézzen, hogy kiismerje magát a világban és iskolán kívüli szûkebb környezetében. Ez a háttér minden tanár esetében kívánatos, azonban a drámatanárnak elengedhetetlen, mert a felsoroltak a tanórai-osztálytermi ötletek forrásai lehetnek. (Morgan-Saxton, 1989, In: Lipták Ildikó 2006.)" (Körömi, 2016, 163. o.). A felsorolt ismeretek a drámatanárok, drámapedagógusok mellett szakmai táplálékot nyújthatnak bármely pedagógusnak. Ebben az eltérő korosztályok érdeklődésének és befogadóképességének ismerete elengedhetetlen bizonyul, főleg ha bármely szakmabeli hatékonyan szeretné végezni a munkáját - legyen szó a bölcsödétől a felnőttképzésig.

Egy frissen végzett pedagógus hallgató életében mérföldkőnek számít a diploma megszerzése és az utána elkövetkezendő időszak is változásokkal teli - nemcsak szakmailag mérettetik meg, hanem az élet más területein is. $\mathrm{Ha}$ a diplomaszerzés időszakát követően rögtön állást kap egy kezdő tanár, és munkába is áll, még gyakran adódhatnak tapasztalatlanságából származó bizonytalanságai. Ha a friss diplomás tanár ebben az időszakban részt venne egy drámapedagógiai képzésen, láthatná, érezhetné, tapasztalhatná magán a pozitív változásokat. Például a drámás gyakorlatok által magabiztosabbá válna az előadásmódjában, az osztálytermi környe- zetben történő bizalomteljes légkör kialakításában - tehát fejlődne a különböző tanári kompetenciáiban (Hivatal, 2020). A drámapedagógia segítségével - ha maga a pedagógus résztvevőként van jelen pályakezdőként megélt frusztrációik oldottabbá válhatnak. „Szerepjátékról akkor beszélünk, ha valaki egy másik személy szerepét vagy funkcióit játssza el. Például ha az előbb leírt mikrotanítási szituációban az iskolásokat egyetemisták helyettesítik, már nem szimulációról, hanem szerepjátékról van szó.” (Falus, 2007, 242. o.). A fejlődési terület függ a drámás képzés tematikájától, céljától is, de a mások által tartott szabályjátékok, adaptációk és a vizsgákra összeállított számtalan tanítási drámán való részvétel egy kötetlenebb mikrotanítási gyakorlatként is értelmezhetô.

„Keveset tudunk a jelenleg létező színházpedagógiai gyakorlatok közvetett és közvetlen oktató-nevelő hatásairól, illetve arról, hogy az iskolák milyen arányban és milyen hatékonysággal tanítják a tantárgyat.” (Kaposi, 2015, 2. o.). A már többször említett 2015-os kutatás, melyet Szabó Zsófia nevével együtt olvashattunk egy olyan projekt része volt, melyre $\mathrm{Ka}$ posi József is utal. „A drámaoktatás helyzete a köznevelésben és a színházi nevelés a köznevelés eredményességéért" című pályázat egy projekt, a TÁMOP 3.1.15. részeként jöhetett létre. A Drámapedagógiai Magazin 52. számában Szabó Zsófia munkája mellett még számtalan írás született a dráma jelenlegi helyzetéről. Bethlen- 
falvy Ádámék szintén részt vettet pozitív eredményről beszámoló kutatásban, aminek beszámolója 2010-ben jelent meg.

A projektben tizenkét ország vett részt: Magyarország mint vezető, és további partnerekként Csehország, Egyesült Királyság, Hollandia, Lengyelország, Norvégia, Palesztina, Portugália, Románia, Svédország, Szerbia, és Szlovénia. (DICE Konzorcium, 2010). A beszámolóban összefoglalják azokat az eredményeket, melyek bizonyítják, hogy a drámás foglalkozásokon résztvevő diákokon milyen pozitív változásokat véltek felfedezni. Ezzel kapcsolatban felmerülhet az a kérdés, amiről már szót ejtettünk: milyen tanárrá válik az a személy, aki fiatalon találkozott, vett részt „drámás foglalkozásokon”? Dudás Margit szavait idézve olvashattuk már, hogy „az ilyen háttérrel rendelkező tanárjelöltek eredményesebben oldották meg a kapcsolatteremtési, kommunikációs képességek működését igénylő feladatokat (Dudás, 1984; Komlósi, T. Dudás, Vastagh, 1987).” (Dudás, 2013). A DICE Konzorcium hipotézisében megfogalmazta, hogy a tanítási színház és dráma a nyolc „Lisszaboni Kulcskompetencia” közül ötre lesz befolyással. Megállapíthatóvá vált, hogy a diákok, akik részt vettek a foglalkozásokon:

- „tanáraik értékelése szerint minden szempontból jobb teljesítményt nyújtanak;

- magabiztosabbak azokban a feladatokban, ahol olvasniuk kell, vagy meg kell érteniük valamit;
- magabiztosabban kommunikálnak;

- inkább tartják kreatívnak önmagukat;

- jobban szeretnek iskolába járni;

- nagyobb örömüket lelik az iskolai feladatokban;

- jobban oldják meg a problémákat;

- hatékonyabban küzdenek meg a stresszel;

- jobb a humorérzékük;

- jobban érzik magukat otthon" (DICE Konzorcium, 2010).

A huszonkettő vázlatpontból itt most tíz lett kiemelve, ámbár ezekből is kitűnik, hogy az iskolai tevékenységek és a személyiségjegyekre gyakorolt hatások mellett a diákok világhoz való viszonyulásában (például humorérzék) is felfedezhető a változás, de a kontrollcsoporton nem. „Mindannyian tudjuk, hogy a gyerekek tanulási folyamatának legnagyobb része a játékon keresztül valósul meg." (Mérei és V. Binét, 1997, 122. o.). Tehát a drámapedagógia által elért pozitívumok az iskolai kereteken is túlnyúltak: a résztvevők másokról és önmagukról alkotott képükre, a kapcsolatrendszereikre, hozzáállásukra, motivációjukra is befolyással bírt.

Az eredményeket szemlélve jogosan merülhetne fel bárkiben (gyerekben, szülőben, pedagógusban) az az igény, hogy ezeket a pozitívumokat a fiatal a felnőtté válás alatt és után is meg tudja őrizni, tovább tudja fejleszteni és adni. „A pedagógus a csoport és a csoportfejlődés pszichológiai, szociológiai, kulturális sajátosságainak ismeretében képes olyan pedagógiai helyzeteket teremteni, amelyek elő- 
segítik a tanulók szűkebb és tágabb közösségek iránti elkötelezettségét, amelyek alapján nyitottá válnak a demokratikus társadalomban való aktív részvételre, a helyi, a nemzeti és az egyetemes emberi értékek elfogadására. Képes a tanulói közösségeket tudatosan szervezni, a konfliktusok építő megoldását segíteni és előmozdítani az iskolai demokráciát." (Pedagóguskompetenciák és a Pedagógus I. szint sztenderdjei, 2. o.). A drámatanárról elmondható, hogy a teljes személyiségét áthatja a tárgyának eszmerendszere és nem tud kilépni belőle: megjelenik a nevelési módszereiben, a tanórán kívüli tevékenységében. A drámatanár még más szaktárgy oktatásában is a cselekvésre buzdító, aktivizáló eszközt részesíti előnyben. A „drámás” módszertan elsődleges szerepet tölt be a közösségi létben, a pedagógus iskolai cselekedeteit - pozitív értelemben - olyannyira átszőve, hogy nem tud kilépni a drámatanári szerepből. Ezt az aktivizáló tanári mintát minden pedagógusjelöltnek (reál- és humán szakon is) ismernie kellene, mert nem biztos, hogy találkozott vele.

\section{EGY LEHETSÉGES KUTATÁSI TERÜLET}

Kutatás cél lehet azt vizsgálni, hogy a drámapedagógia milyen pedagógiai, személyiségfejlődési hatással bírhat a gyakorló- vagy pályakezdő pedagógusokra, illet- ve, hogy ezek a hatások miben és hogyan nyilvánulnak meg.

E vizsgálat során a következő kérdésekre kereshetnénk, találhatnán válaszokat:

1. Napjainkban milyen nehézségekbe ütközi egy pályakezdő pedagógus és ebben milyen segítségére lehet a drámapedagógia módszere?

2. Fejlesztő hatással van-e a drámapedagógia módszere a tanári kompetenciák gyakorlására, és ha igen, hogyan?

3. Szükséges-e a drámapedagógiát beépíteni a felsőfokú pedagógusképzésbe?

Egy ilyen kutatás tehát elősorban a pályakezdő pedagógusokra vonatkozó hatásokat vizsgálná, amelyeknél kvalitatív és kvantitatív kutatási módszerek kerülnének előtérbe. A kutatási minta alapját a gyakorló és pályakezdő pedagógusok jelentenék, azok, akik nem találkoztak vele, érdeklődnek a módszer iránt és szeretnének megismerkedni a drámapedagógiával, vagy mélyíteni kívánják a témában szerzett ismereteiket. Egy korábbi vizsgálathoz (Varga-Csikász, 2018) alkotott kérdőívet tovább gondolva, módosítva azt, lehetne egy nagyobb létszámú csoporthoz eljuttatni, főként az új generációs pedagógusokra gyakorolt hatást vizsgálva.

Induktív módszerrel lehetne megközelíteni azt a kérdést, hogy a pedagógusok hogyan készülnek egy-egy drámapedagógiai foglalkozásra, akár rendelkeznek ebben nagyobb tapasztalattal, akár nem. Kutatási szempontból fontos lehet, hogy a rutin vagy annak hiánya hogyan hat a 
részvevőkre, illetve a játékvezetőre a dráma eszközeinek használata közben.

Az tervezett órákról hospitálási naplók is készíthetők, melyek tartalomelemezéssel vizsgálhatók és összehasonlíthatók az órára készített foglalkozás tervével. Az önreflexiókat a dokumentumelemzés módszerével lehetne feldolgozni.

A mérések alkalmával panelvizsgálatok is végezhetők, így további kutatás létrehozása is lehetséges annak érdekében, hogy adatokat kapjunk arról, milyen eltérések figyelhetők meg a tanári kompetenciákban a drámaképzés előtt és után.

A kutatás várhatóan alátámasztaná, hogy a drámapedagógiának meghatározóbb helye lehetne az oktatásban. A XXI. században a nevelési intézményeknek - a felnövekvő generációkat ért hatásokat fokozottan tanulmányozva és követve - a tárgyi tudás átadása mellett közösségépítő, személyiségfejlesztő módszerekre nagyobb hangsúlyt kell helyezniük : „Az iskola olyan értékrend kialakításához járul hozzá, amely megalapozza, hogy az egyén személyes boldogsága mellett értékesnek tekintse a társadalmi együttéléshez szükséges kötelezettségek teljesítését és a különböző társadalmi szerepek betöltését. A köznevelés célja és feladata az, hogy támogassa a fejlődő-kibontakozó egyént a harmonikus egyensúly megtalálásában..." (A Nemzeti alaptanterv tervezete, 2012, 1. o.). Az ember és technika viszonyába a technikát, mint eszközt kell megtartani, és a személyes jelenlétet áthidaló lehetőségei mellett a fiatalokat tudatosabb használatra nevelni vagy ösztönözni, mivel sokszor jobban értenek hozzá, mint az idősebb generációk. Ahhoz, hogy az iskola fő funkcióját betöltve az életre nevelje a gyerekeket, olyan pedagógustársadalom képzésére van szükség, akik - változó oktatási és techno-lógiai környezethez, tanulói sajátossá-gokhoz alkalmazkodva - személyiségük és jelenlétük mellett továbbra is mintaként szolgálnak az oktasi, tanulási eszközök használatában, közösségépítő tevékenységeik szervezésében, levezetésében.

\section{ZÁRÓGONDOLATOK}

A drámapedagógia, mint az általánosságban elmondható, bár nem alkalmazható mindig minden helyzetben és minden csoportban, de olyan közösségépítő, ventilálási, átélési, gondolkodtatási lehetőségeket kínál, melyeket minden pedagógusnak ismernie, alkalmaznia és terjesztenie kell. A módszert a gyerekek és önmaguk személyiségének színesítésére is használhatják. „Minden, ami a nyilvánosság előtt játszódik, olyan, mint a színház. Éppen ezért, akiket rövid időn belül a közéletbe küldenek, úgy neveljék, hogy ott megfelelően állják meg a helyüket, s a rájuk bízott feladatokat kellően végezzék el. (»Schola Ludus«, Sárospatak, 1656)" (Gabnai, 1999). A szerepek megfelelő alkalmazását, védő funkcióit, fel- és levételét, a szociális érzékenyítést pedig ugyanúgy tanítanunk kell, mint a tárgyi tudás megszerzését. 
A pedagógussá válással kapcsolatban már kitértünk a drámapedagógia jelentőségére. Ha a pedagógusjelöltnek a középiskolában nem adódott meg, hogy megélje ennek a módszernek a személyiségfejlesztő hatását, akkor az egyetemek - az újabb életszakaszok nehézségeire is válaszokat, feloldásokat keresve - fel kellene kínálniuk ezt a továbbképzési lehetőséget. A drámapedagógia az általános tanárképzésbe bekerülve az új szerepek megélésében, az új kapcsolatok kiépítésében, önreflexió elsajátításában kínálhat gyakorlatot. „Szükség van a kudarctűrő képesség fejlesztésére is, és nem csak a szakmaiintellektuális vonatkozásban. Hiszen a tanulmányok kezdete egyben a felnőtté válás kezdete a maga sajátos életfeladataival és csalódásaival, mint a próbálkozás és feladás, a partnerkapcsolat-teremtés és szakítás, a tervezés és kudarcba fulladás." (Bikics, 2013).

A fentebb felvetett kutatás tehát várhatóan adatokkal szolgáltahat arra, hogy a drámapedagógia a tanári kompetenciákra a pedagógusok gyakorlati és pályakezdő éveiben nagy jelentőséggel bír, ezért az új generációs pedagógusok oktatásában elengedhetetlen lesz a dráma eszközeinek használata, mert „,a dráma mint megközelítésmód »az oktatásban végbemenő kreatív forradalom« (Burges, 1986) egyik példája." (Szauder, 2013).

\section{IRODALOM}

110/2012. (VI. 4.) Korm. rendelet A Nemzeti alaptanterv kiadásáról, bevezetésérõl és alkalmazásáról

A Nemzeti alaptanterv tervezete (2018). Letöltés: 2020.04.30. Web: https://www. oktatas2030.hu/wp-content/uploads/ 2018/08/a-nemzeti-alaptanterv-terve zete_2018.08.31.pdf

Bethlenfalvy Á. (2017). Színházi nevelési programok - nemzetközi kitekintés. In Cziboly Á. (Szerk.): Szinházi nevelés és szinháapedagógiai kéziłoünyv (112-145. o.). InSite Drama. Letöltés dátuma: 2020. 04.29. Web: https://www.szinhazineveles.hu/wpcontent/uploads/2018/01/Szinped_P rog_Final_6.pdf

Bethlenfaly Á. (2005). Fejezetek az angol drámapedagógiai történetéből (2.). Drámapedagógiai Magazin, 16-23. Letöltés: 2020.04.30. Web: http:/ / epa.oszk.hu/03100/03124/000 40/pdf/EPA03124_dpm_2005_1_016 -023.pdf

Bikics G. (2013). Tanulóból tanárrá válni. Kihívások, nehézségek és segítségnyújtási lehetőségek a pedagógussá válás kezdetén. In Golnhofer E. és Kotschy B. (szerk.): Új utak a pedagóguskutatásban. EKF Líceum, Eger. 7-26.

Bolton, G. (1993). A tanitási dráma elmélete. Marczibányi Téri Művelődési Központ, Budapest.

Bolton, G. (1996). A tanítási dráma újragondolása. Drámapedagógiai Magazin Különsqám. Letöltés: 2020.04 29. Web: 
http://epa.oszk.hu/03100/03124/000 14/pdf/EPA03124_dpm_1996_k.pdf DICE Konzorcium. (2010). DICE - a kocka el van vetve, Kutatási eredmények és ajánlások a tanitási szinház és dráma alkalmazásával kapcsolatban. Letöltés: 2020.04.10. Web: http://www. dramanetwork.eu/file/DICE_kutatasi _eredmenyek.pdf

Dudás M. (2013). „Az iskola egy színház, és ebben a színházban a tanár a dramaturg...”. In Golnhofer E. ésB. Kotschy B. (szerk.): Új utak a pedagóguskutatásban. EKF Líceum, Eger. 5571.

Eck J., Takács G. és Neudold, J. (Előadók). (2019. 11 19). Kinyílt az aranykapu? Szinházi nevelés és a rendszerváltás. Revizor OFFline, Magvető Café, Budapest.

Eck J. (2015). A dráma helye a közoktatásban. Drámapedagógiai Magaẓin, 5-7. Letöltés: 2020.04.30. Web: http:/ /letoltes.drama.hu/DPM/20152017/2015.2.pdf

Eck J. (2016). A dráma helye a közoktatásban és a tanárképzésben. In K. Illés (Szerk.): Dráma, pedagógia, szinháą, nevelés: szöveggyüjtemény köréphaladóknak. Budapest: OFI. 91-113. Letöltés: 2020.04.10. Web: http://ofi.hu/sites/ default/files/attachments/dramapeda gogia_online.pdf

Falus I. (Szerk.). (2007). Didaktika - Elméleti alapok a tanitás tanulásához. Nemzeti Tankönyvkiadó, Budapest.

Falus I. (2013). Új tendenciák a tanártovábbképzés nemzetközi. In Falus I.
(Szerk.): Pedagógus-továbbképzés, Nemzetközi áttekintés. Líceum Kiadó, Eger.

Gabnai K. (1999). Drámajátékok - Bevezetés a drámapedagógiába. Helikon Kiadó, Szekszárd.

Habos D. (2018). A pedagógus tanórai és órán kivüli tevékenysége a digitális kompetencia és a mediatudatosságra nevelés tükéében. Kutatási terv. Eszterházy Károly Egyetem Neveléstudományi Doktori Iskola.

Heathcote, D. (2013). A konvenciókról. In Kaposi L. (Szerk.): Drámapedagógiai olvasókönyv. II. Kerületi Kultúrális Közhasznú Nonprofit Kft. Marczibányi Téri Művelődési Központ, Budapest. 123-125-

Pedagóguskompetenciák és a Pedagógus I. szint sztenderdjei. Oktatási Hivatal, Budapest. Letöltés: 2020.04.30. Web: https://www.oktatas.hu/pub_ bin/dload/pem/Pedagogus_I_sztende rdek.pdf

Hull, S. (1999). Szinészmesterség mindenkinek. Tericum Kiadó Kft., Budapest.

Kaposi J. (2015). Bevezető. Drámapedagógiai Magaz̨in, 2. Letöltés: 2020.04.30. Web: http://epa.oszk.hu/03100/ 03124/00081/pdf/EPA03124_dpm_2 015_2.pdf

Körömi G. (2016). Drámapedagógusok az oktatásban. In Illés K. (Szerk.): Dráma, pedagógia, szinház, nevelés: szöveggyüjtemény középhaladóknak. Oktatáskutató és Fejlesztő Intézet, Budapest. 159-178. Letöltés: 2020.04.30. Web: https:// 
ofi.oh.gov.hu/sites/default/files/attac hments/dramapedagogia_online.pdf

Magyar Drámapedagógiai Társaság. Letöltés: 2020.04.29. Web: https://drama. hu/magyar-dramapedagogiai-tarsasag/ Mérei F. és V. Binét Á. (1997). Gyermeklélektan. Medicina, Budapest..

Neelands, J. (2013). A drámát érintő alapvető gondolatok. In Kaposi L. (Szerk.): Drámapedagógiai olvasókönyv. II. Kerületi Kultúrális Közhasznú Nonprofit Kft. Marczibányi Téri Művelődési Központ, Budapest. 8-10.

Papp G. és Trencsényi L. (szerk.)(1984). Szinjátszás - dramatikus nevelési program 1972-1982. Népművelődési Intézet, Budapest.

Pukánszky B. és Németh A. (1996). Neveléstörténet. Nemzeti Tankönyvkiadó, Budapest.

Szabó Z. (2016). Drámapedagógia a köznevelés információs rendszerében. statisztikai adatok tükrében. In Illés K. (Szerk.): Dráma, pedagógia, színház, nevelés: szöveggyüjtemény középhaladóknak. Oktatáskutató és Fejlesztő Intézet, Budapest. 65-90. Letöltés: 2020. 03.20. Web: http://ofi.hu/sites/default/files /attachments/dramapedagogia_online .pdf

Szauder E. (2013). A dráma mint pedagógia. In Kaposi L. (Szerk.): Drámapedagógiai olvasókönyv. Magyar Drámapedagógiai Társaság, Marczibányi Téri Müvelődési Központ, Budapest. 11-26.

Szőke-Milinte E. (2019). A Z generáció megismerése - megismerés a $Z$ generációban. In J. Kaposi J. és. SzőkeMilinte E. (szerk.): Pedagógiai változások - a változások pedagógiája. Pázmány Péter Katolikus Egyetem. Budapest. 130144. Letöltés: 2020.04.29. Web: http://btk.ppke.hu/uploads/articles/ 1734918/file/Pedag\%C3\%B3giai $\% 20$ v\%C3\%A1ltoz $\%$ C3\%A1sok $\% 20 \mathrm{~B} 1 \%$ 2BB4\%2Bbel $\%$ C3\%ADv $\% 20$ screen.p df

Tölgyessy Zs. (2011). A drámapedagógiai jelenléte a Vág-Duna-Ipoly eurorégió irodalomóráin. ELTE, Budapest. Letöltés: 2020.04.29. Web: https:// ppk.elte.hu/file/tolgyessy-zsuzsanna_ dissz.pdf

Varga-Csikász, Cs. (2018). A drámapedagógia jelene a mai magyar oktatásban. Szakdolgozat, Pázmány Pétet Katolikus Egyetem, Piliscsaba. 
MÓDSZERTANI TANULMÁNYOK 


\title{
MULTIPROFESSZIONÁLIS REHABILITÁCIÓS TEAM KOMMUNIKÁCIÓJÁNAK VIZSGÁLATI LEHETŐSÉGEI
}

\author{
Szerző: \\ Angeli Csenge \\ SZTE Gyermekgyógyászati Klinka
}

Szerző e-mail címe: angelicsenge@gmail.com

\author{
Lektorok: \\ Feketéné Dr. Szabó Éva \\ Semmelweis Egyetem \\ Dr. Túri Ibolya \\ Semmelweis Egyetem \\ ...és további két anonim lektor
}

\begin{abstract}
Absztrakt
A magas rehabilitációs költségek csökkentése érdekében nagy jelentőségűek a rehabilitációs team hatékonyságára fókuszáló kutatások, így a kommunikációs vizsgálatok. Jelen tanulmány célja, hogy összegezze azokat a módszereket, melyekkel e kommunikációs mérések elvégezhetőek, kijelölve az utat következő, empirikus kutatásoknak. A team kommunikációjának mérését leggyakrabban a team-megbeszélés alkalmával vizsgálják, ezen felül azonban számos lehetőség áll rendelkezésünkre. A kép- és hangrögzítés nehézségeit más módszerekkel kombinálva kiküszöbölhetjük, illetve csökkenthetjük. Ez a tanulmány a potenciális vizsgálati helyzeteket és a gyakrabban alkalmazott módszereket összegzi.
\end{abstract}

Kulcsszavak: rehabilitáció, kommunikáció, team-kommunikáció

Diszciplina: orvostudomány

\section{Abstract}

MEASURMENT POSSIBILITIES

OF MULTIPROFESSIONAL REHABILITATION TEAM COMMUNICATION

In order to reduce high rehabilitation costs, research focusing on the effectiveness of the rehabilitation team, such as communication studies, is very important. The aime of the present study is to summarize the methods by which these communication measurements can be performed, marking the way for later empirical researches. Measuring team communication is most often examined during a team meeting, but in addition, we have number of options. The difficulties of image and sound recording 
can be eliminated or reduced when combined with oder methods. This study summarizes potential examination situations and commonly used methods.

Keywords: rehabilitation, communication, team communication

Discipline: Medicine

Angeli Csenge (2020): Multiprofesszionális rehabilitációs team kommunikációjának vizsgálati lehetőségei. OxIPO - interdiszciplináris tudományos folyóirat, 2020/3, 75-85. doi: 10.35405/OXIPO.2020.3.75

Az orvosi rehabilitáció költségei világszerte rendkívül magasak úgy gyermek-, mint a felnőtt kórképekben. Jó példázza ezt a rehabilitációs ellátást igénylő kórképek közül kiemelkedő Cerebralis Paresis (CP), melynek prevalenciája 2-4/1000 gyermek a 3-10 éves korosztályban (Cans, 2000) valamint a Stroke, melynek incidenciája 45-50 ezer fő/év, prevalenciája 180-200 ezer (Szende, Oppe és Devlin, 2006) és a leggyakoribb tartós rokkantágához vezető állapot. Az előbbi esetén 2019-es felmérés alapján Magyarországon egy gyermek költsége 18 éves koráig 73 millió HUF (251 $724 €$ ), valamint a GDP 0,525\%-át, a teljes egészségügyi és szociális költségvetés 0,88\%-át és a közvetlen orvosi költségek 1,83\%-át költötték a CPs családokra. (Fejes, Varga és Hollódy, 2019) A stroke évi 38 milliárd euróval az Európai Unió (EU) teljes egészségügyi kiadásainak 2-3\%-át teszi ki (Allender, és tsai., 2008).

A rehabilitációs ellátás eredményességének növelése lehet a kulcs a magas össz- gazdasági terhek csökkentésének, figyelembe véve - az említett kórképek példáján - az elhúzódó rehabilitációs szakasz, valamint a rehabilitáció sikerességtől függő posztrehabilitációs szakasz költségeit. Az ellátás rendelkezésére álló erőforrásainak optimalizálásával nem csupán az akut rehabilitációs szakaszban csökkenthetőek a költségek, de a várhatóan jobb funkcionális kimenetnek köszönhetően a hoszszútávú társadalmi és egyéni terhek is redukálhatóak. Az egyik legjelentősebb, e területen a rendelkezésünkre álló erőforrás a teambe rendezett humánerő. Jesus és Silva (2016) megállapítása szerint a rehabilitációban alkalmazott kommunikáció direkt és indirekt úton is befolyásolja a rehabilitáció eredményességét. Ennek fényében érdemes a rehabilitációs team kommunikációjával, mint a rehabilitáció egyik jelentősen befolyásoló tényezőjével foglalkoznunk, annak hatékonyságát, javíthatóságát az egyes teamekre vonatkoztatva megállapítanunk, hogy e mérések segítségünkre legyenek az általánosan le- 
vonható következtetések és ajánlások megfogalmazásában. A team struktúra feltérképezésével, a kommunikációs hibák feltárásával és javításával, a team tagjai közti konfliktusok felszínre emelésével, az egyéni kommunikációs hibák feltárásával lehetőség nyílik a dolgozók képességeinek adekvát fejlesztésére, a megfelelő munkahelyi légkör kialakítására és a hatékonyság fokozására. A szakmák közti esetleges ellentét, vagy a szakma alacsonyabb presztízséből fakadó feszültség is felszínre kerülhet többek közt a tartalmi elemzés hatására. A humánerő bevonásával (a vizsgálati eredmények ismertetése, megoldási módok, javaslatok biztosítása) a dolgozó kompetensebbé válhat a felmerülő problémák megoldásában.

Jelen tanulmány célja, hogy összegezze azokat a módszereket, melyekkel a multiprofesszionális rehabilitációs team kommunikációja mérhető, annak érdekében, hogy megalapozza a később erre építhető kutatásokat.

\section{A REHABILITÁCIÓS TEAM SAJÁTOSSÁGAI}

Az orvosi rehabilitáció sajátos tulajdonsága, hogy az egészségügyre jellemző hierarchikus rendszerbe ágyazva, a rehabilitációs ellátás igényeinek megfelelően, más egészségügyi ellátásra nem jellemző felépítésű, multiprofesszionális teammunkán alapul.

A team összetétele kórképenként, illetve betegenként is változhat. (Kullmann,
2010) A team tagjai eltérő szaktudással és rálátással, más-más háttérrel rendelkeznek. Kullmann és Vekerdy (2006) alapján a legfontosabb team tagok a következők: rehabilitációs szakorvos, ápoló, szakápoló, fizioterapeuta (gyógytornász), szakgyógytornász, kineziológus, konduktor, foglalkoztató terapeuta, klinikai szakpszichológus, neuro-pszichológus, logopédus (beszédterapeuta), szomato-pedagógus, testnevelő tanár, gyógytestnevelő, fizikoterápiás asszisztens, gyógymasszőr, dietetikus, ortopéd műszerész.

A teamben megtalálható egyes szakemberek képzése jellemzően más felépítésû munkakörnyezetben végzett tevékenységre készítik fel hallgatóit. Így például az orvosok (a rehabilitációs szakorvos képzést nem számítva) és ápolók az egészségügyi team munkára, az ott megszokott hierarchikus rendszerre kapnak felkészítést, (Kullmann, 2010) a gyógypedagógusok, konduktorok jellemzően inkább pedagógus munkaközösségekben, tantestületekben, az oktatási szféra jellemzőire készülnek (Kullmann, 2015). A szakmák eltérő szemlélete és terminológiája tovább bonyolítja a munka közös irányának kialakítását. A szakemberek képzésében kevéssé, vagy egyáltalán nem kap szerepet a teammunkára felkészítés (Kullmann, 2015).

A problémák áthidalását elősegítheti a közös nyelv kialakítása, melyre jó példa a funkcióképesség, fogyatékosság és egészség nemzetközi osztályozása (FNO) használatának bevezetése (Allan és tsai, 
2006; Tempest és McIntyre, 2006). A team felépítésétől függően a team tagjai a más szakmák által használt terminológiák ismeretére és megértésére való törekvéssel, akár annak használatával tudják elősegíteni a közös munkát.

A rehabilitációban a teammunkának alapvetően három modelljét különítjük el: a multidiszciplináris, az interdiszciplináris és transzdiszciplináris modellt. A különböző team működési formákban a team tagjai közti viszonyban jelentős eltéréseket találunk, melyek a kommunikációs mintázatokban is jelentkeznek.

Multidiszciplináris team esetén a team minden tagja önállóan, egyénileg végzi munkáját, a team vezetőjének felel, vele áll közvetlen és közeli kapcsolatban (Norrefalk, 2003). Interakció így leggyakrabban a team egy tagja és a team vezetője közt, illetve a team egy tagja és a páciens, vagy hozzátartozója közt jön létre.

Interdiszciplináris teamekre jellemző, hogy bár a tagjai szintén egyénileg végzik munkájukat, azonban kölcsönös konzultációk alkalmával zajlik kommunikáció a team tagjai közt. A célok és a rehabilitációs terv a pácienssel és családjával is egyeztetésre kerülnek. Lehetőség nyílik ilyen módon közös vélemény és kezelési menet kialakítására, melyet a szakemberek saját tevékenységükbe integrálva hajtanak végre (Körner, 2010). A kommunikáció a team minden tagja közt zajlik, gyakoriságában és irányában azonban találhatunk aszimmetriákat.
Az oktatási modellből kifejlődő transzdiszciplináris team modell ismérve a kommunikációt meghaladó együttmúködés. A közösen végzett vizsgálatok és a tapasztalatok közös kielemzésén túl a pácienssel és családjával is még szorosabb együttmúködés létesíthető. $\mathrm{E}$ teamen belüli kooperáció sajátosságai a szerepkiterjesztés, szerepszélesedés, szerepátadás, szerepmegosztás, valamint a szerepsegítés (Lyon és Lyon, 1980; Woodruff és McGonigel, 1988; King és tsai, 2009). Ez a modell az, melyben leginkább hangsúlyos a rendszeres kommunikáció és az információcsere (Kullmann, 2015).

A team, annak múködési formájától függetlenül, folyamatos változáson esik át. Új team tag bekerülésével vagy távozásával a korábbi, megszokott munkarend felborul, az új helyzethez való alkalmazkodást követően pedig új rend alakul ki. Ezt a folyamatot team-dinamikának nevezzük. Főbb állomásai a következők: az ismerkedés szakasza (forming), a feszültség szakasza (storming), a csoportnormák kialakításának szakasza (norming), az érdemi munka szakasza (performing) és a szétválás szakasza (adjourning) - (Tuckman, 1965; Tuckman és Jensen, 1977).

A rehabilitációs munka szervezésének sajátossága az egészségügyi rendszerre jellemző munkaközösséggel szemben (bár az orvosi gyakorlat más területein is találhatunk elmozdulást a páciens partneri viszonyba helyezése felé), hogy a páciens és családja a team aktív tagja. 
A fent felsorolt modellek mindegyikére igaz ez, csupán a részvételi arányban találunk eltérést.

A team kommunikációjának mérésekor érdemes figyelembe venni a teamdinamikát, előzetesen felmérni, hogy a vizsgált team nyugvó, vagy változó fázisban van-e, illetve ha ez utóbbi eset áll fenn, akkor mely szakaszban tart a változás, hogy a team-dinamika fázisok kommunikációt befolyásoló hatását figyelembe véve tudjuk az eredményeket értékelni.

\section{A MÉRÉS TÁRGYA}

A kommunikáció, mint esetünkben vizsgálandó jelenség a team szintjén jelentkező folyamat. Minden kommunikációs folyamatban a team legalább két tagja vesz részt. Két résztvevő közti interakció gyakran fordul elő minden rehabilitációs teamben, leggyakrabban mikor a team egyik szakértő tagja a pácienssel lép kapcsolatba és fordítva. Ezen felül a team szervezett találkozásain kívül - melyet a későbbiekben tárgyalunk - a tagok spontán, szabadon szerveződő kisebb csoportjai is kommunikálnak egymással, vegyes team összetételben. A továbbiakban a team szervezett találkozásainak mérési lehetőségeit vesszük számba, a spontán szereveződő team-interakciós vizsgálatokat nem tárgyaljuk, figyelembe véve annak mérési nehézségeit. Ugyanakkor e helyzetek team hatékonyságra gyakorolt vélhető hatása, illetve a hatékonyság indikátoraként betöltött szerepének lehetősége okán e terület feldolgozását egy későbbi tanulmányban vesszük górcső alá.

A szervezett team találkozások esetén mérhetők az egyén, illetve a vizsgált csoport (team egyes tagjai vagy a teljes team) interakciós megnyilvánulásai. Az egyén szempontjából (eltekintve az intraperszonális kommunikáció vizsgálatától), a verbális és nonverbális megnyilvánulások rögzítése kézenfekvő. A teamet alkotó szakmákra külön-külön vonatkozó szakirodalomban (orvos-beteg kommunikáció, pedagógus kommunikációja, stb.) a kommunikáció formai és tartalmi, valamint mennyiségi vizsgálata jellemző. Ilyen például a beszéd és annak stíluselemei, az érthetőség, egyértelműség, a megértés, a non-verbális megnyilvánulások, illetve azok viszonya a verbális kommunikációhoz. Az orvos-beteg találkozás vizsgálatainak megállapításai rendkívül jelentősek lehetnek, tekintve a teamen belüli szakember-páciens gyakori - és a kezelések, foglalkozások alkalmával hosszú ideig tartó- találkozását. Az egyéni szintű adatok alapján a team tagjának teamben betöltött szerepéhez viszonyított kommunikációs tevékenysége (például a team vezetőjének verbális és nonverbális megnyilvánulásai mennyiben tükrözik pozícióját) is felszínre kerülhet. Ennek jelentősége abban állhat, hogy a teljes team vizsgálatakor kapott egyes eredmények, ha teljes magyarázatot nem is kapnak, de a team tagjai közti viszony egyik dimenzióját alkotva a team hangulatának, szorongási szintjének egyik magyarázó oka lehet, természetesen a to- 
vábbi körülmények gondos vizsgálata és figyelembevétele mellett. További haszna lehet a humánerő fejlesztés szempontjából, hogy a teamben betöltött szerepre vonatkoztatva kapott eredmények által fény derülhet a dolgozó bizonytalanságára, egyes hibáira, melyek ily módon javíthatóvá válhat, a munkaerő adekvát irányú továbbképzése és fejlesztése megvalósulhat, ezáltal javítva a team hatékonyságát.

A több résztvevős kommunikációs helyzetek vizsgálatában az egyéni szintű megfigyelésből nyert adatok és eredmények (nonverbális megnyilvánulások, a verbális és nonverbális kommunikáció viszonya, stb.) megfelelő kontextusba kerülnek. A team egyes csoportjainak, illetve a teljes team vizsgálatát több szempont alapján is végezhetjük. Lehetőségünk nyilik a tagok interakcióinak irányát és mennyiségét mérve a tagok aktivitását meghatározni, valamint következtethetünk a teamben képviseltetett szakmák preferációjára és megállapíthatjuk a vizsgált csoportban alkalmazott team modellt is. Hámornik (2013) az általa vizsgált rehabilitációs teamben például az orvos központi szerepén túl rámutat a gyógytornász szakmát és az ápoló szakmát képviselők közti kommunikáció alacsony mértékére a gyógytornász-orvos, illetve az ápoló-orvos kommunikáció mennyiségéhez képest.

\section{A TEAM-INTERAKCIÓK HELYE}

A következőkben áttekintjük a team találkozásokat, melyek a mérés helyeként szolgálhatnak. A tervezett interakciók a következő fontosabb tevékenységekhez köthetőek a rehabilitációs gyakorlatban:

- Team-megbeszélés,

- „Kis” team-megbeszélés,

- Vizitek, heti nagyvizit,

- Több team tag részvételével végzett betegvizsgálat,

- Egyéni megbeszélések, állapotfelmérés, terápiák,

- Dokumentáció elemzése.

Team-megbeszélés során bár a team teljes létszámmal nem lehet jelen az ügyeletek és az eltérő múszakok miatt (például ápolók esetén), ugyanakkor a munkában résztvevő minden szakma képviselteti magát. Jellemzően heti egy alkalommal vagy kéthetente szervezett megbeszélés, a páciens részvétele nélkül zajlik, s a rehabilitációs osztályon ellátott minden beteg megbeszélésre kerül (Bokhour, 2006). Ezen alkalommal áttekintésre kerül a betegek állapota, igényei illetve itt történik a közös célmeghatározás is (Bokhour, 2006). „Kis” team-megbeszélésen a team minden tagja nem vesz rész, csupán a beteg és hozzátartozója valamint a páciens felmerülő problémáival kapcsolatban kompetens, a beteggel közvetlenül foglalkozó team tagok. Az ilyen alacsonyabb számú személlyel történő megbeszélés egyik példája a célegyeztető megbeszélés. Az Országos Orvosi Rehabilitációs Intézetben saját célegyeztető megbeszélés protokollját dolgozták ki, melynek egyik rendeltetése a páciens elvárásainak, saját céljainak megismerését követően a rehabilitációs célok közös kialakítása, mellyel 
lehetőség nyílik a páciens esetlegesen túlzó, irreális elvárásainak a megvalósítható irányba terelése, a későbbi viták és ellentétek megelőzése (Szél és tsai, 2015). A protokoll használata során logisztikai nehézségeket okozott ugyan munkaidőben a különböző beosztású team tagok és a hozzátartozók egyidejü jelenléte, ugyanakkor többek közt a team tagjai közi kommunikáció könnyítését kedvezően befolyásolta, illetve a hozzátartozók is pozitív visszajelzést adtak. Bár alacsonyabb számú személy interakcióinak felmérésre ad lehetőséget ez az alkalom, mégis nagy jelentőséggel bírhat, mivel mind a beteg körüli kezelő személyzet, mind a páciens és közvetlen támogató hálózata jelen van, így olyan folyamatok rögzítésére is lehetőség nyílik, melyre más alkalommal nem lenne lehetőség.

Bár a heti Nagyvizitek alkalmával is jelen van a páciens, a vizsgáló team mozgásban van, szisztematikusan halad végig az osztály kórtermein betegtől-beteghez tartva. Ezeken az alkalmakon a kórteremben tartózkodó összes beteg hallja az elhangzottakat, továbbá a jelen lévő szakemberek közt nem csupán a beteggel közvetlenül foglalkozó team tagok vesznek rész, hanem jellemzően a teammegbeszélésen jelen lévő teljes team. Emiatt a nagyvizitek alkalmával kevésbé van alkalma a betegnek is és a személyzetnek is a bizalmas kérdések megvitatásásra.

A fenti alkalmak lehetőséget biztosítanak a team-interakciók, a páciens és a szakember-team interakcióinak vizsgálatára. Gyakori kommunikációs helyzet a rehabilitációs ellátás során a beteg vizsgálata és kezelése, melyen egy, vagy az előbbin akár több team tag is részt vehet. Ezen találkozások adhatnak lehetőséget a szakember-páciens interakciók megfigyelésére és vizsgálatára.

A dokumentáció folyamatos vezetése mellett a team-megbeszélés alkalmával is előkerül, ahol a friss beteg-adatokat, célokat rögzítik. Segítségével térben és időben eltérő helyen van lehetőség az információcserére, így annak elemzésével érdemes kiegészíteni a team kommunikációjának vizsgálatát.

A fentiek vizsgálati lehetőségeit és korlátait a következőkben tárgyalom.

\section{A MÉRÉS \\ MÓDSZEREI, ESZKÖZEI}

Az interakciók vizsgálatakor a megfigyelés végzése elengedhetetlen. Ezt természetesen tervszerűen végezzük, így a terepmunkát megelőzően választjuk ki azokat a technikákat, melyeket alkalmazni szándékozunk. A hang és képanyag rögzítése rendkívüli előnyökkel jár: az anyag bármikor visszajátszható, újra elemezhető, az interakció lassításával olyan elemeket is képesek vagyunk elemezni, melyre valós időben nem nyílna lehetőségünk. A nonverbális kommunikáció vizsgálatához kiemelten fontos videó készítés. Kézenfekvő hasznuk mellett ugyanakkor alkalmazásuk több akadályba is ütközik. A képi-és hanganyag rögzítésére szolgáló kamera és 
a csak hanganyagot rögzítő magnó erős zavaró hatásával kell számolnunk. A team tagjai a megszokottól eltérő viselkedést mutathatnak, az interakciók mennyiségi és minőségi mutatói torzulhatnak. A hatás korrigálható szoktatási idővel, ám ez rendkívül időigényes. A kamerahasználat további problematikája annak korlátozott látószöge. A team-megbeszélés során a team tagjai jellemzően asztal mellett, ovális vagy kör alakzatban helyezkednek el, ami miatt több kamera használata válhat szükségessé (Hutchins, 1995). Így természetesen a kamera zavaró hatása is erőteljesebben érvényesülhet. A team-megbeszélés, a „kis” team-megbeszélés helyhez kötötten zajlik, a kommunikáló felek helyüket az interakciósor végéig nem változtatják, így viszonylagosan egyszerű a felvevőegységek beállítása. Vizitek alkalmával viszont a vizsgáló team betegtől betegig halad, a team tagjai egymáshoz képesti helyzetüket és helyüket is változtatják. Ebben a helyzetben a képi anyag, az öszszes résztvevő nonverbális jelzéseinek rögzítése gyakorlatilag lehetetlenné válik. A hangfelvétel készítése is nehézkes: a felvevő eszközt megfelelő távolságon belül szükséges tartani a feldolgozható minőségű hanganyag rögzítése érdekében. A mobilitás problémája kapcsán alternatívát nyújthat például a LENA (Language Environment Analysis/nyelvi környezet elemzés), mely rendszer egy hordozható felvevőegység tárolására alkalmas zsebbel rendelkezik, melyet a vizsgált személyre rögzítve, annak minden verbális reakciója rögzíthetővé teszi (Oller és tsai., 2010). Minden osztályos páciensre alkalmazva rendkívül költségessé válna a vizsgálat, így a teljes vizit hanganyagának rögzítése nem valósítható meg, ugyanakkor egy-egy beteg vizsgálatára alkalmas lehet a rendszer. A terápiák és vizsgálatok egy-egy teremben vagy szobában zajlanak, kevesebb a mozgás, mint a vizitek alkalmával, azonban tapasztalhatjuk itt is a jelenlévők helyés helyzetváltoztatásából, valamint a kamera látószögnek korlátozottságából fakadó problémákat. Ebben az esetben is több eszköz használata válna szükségessé, melyek zavaró hatásán túl az eredmények elemzését bonyolultabbá teszi. A hang és képanyag rögzítése, tárolása és felhasználása - a többi módszer esetében is vezérfonálként és alapkövetelményként betartott kutatásetikai követelményeken túl további engedélyezésekre is szükséges gondolnunk a hatályos jogszabályok értelmében (GDPR).

Bármely interakciós helyzetben a hanganyag felvételhez kiegészítő eljárás alkalmazása szükséges. Ennek egyik lehetősége a jegyzőkönyv, vagy napló készítése, párhuzamosan a hangrögzítéssel. A napló kevésbé kötött rögzítési forma, így alkalom nyilik új, nem várt jelenségek rögzítésére is, melyek segítségével a vizsgálat új aspektusai tűnhetnek fel, megalapozva újabb hipotézisek, elméletek születését és további vizsgálatok facilitálását (Falus, 2004). A jegyzőkönyv sokkal inkább objektív, a megfigyelő személyétôl kevésbé függő megfigyelési forma (Falus, 2004). 
Teljes jegyzőkönyvnek minősül maga a magnó és a videokamera is, ugyanakkor a hanganyag írott jegyzőkönyvvel történő kiegészítése segítséget nyújthat annak pontosítására. Hámornik (2013) online regisztrációs módszert dolgozott ki, melylyel valós időben rögzíthető volt a közlő és a címzett. A hangfelvétel ilyen jellegű kiegészítése lehetővé teszi az adatok pontosítását és gyorsabb feldolgozhatóságát, biztosítja, hogy a hanganyag elhangzott egységeit a megfelelő szakemberhez tudjuk társítani, mely csupán a team tag hangja alapján bizonytalan volna.

A team hatékonyságának felmérése, megtartása vagy fejlesztése érdekében végzett team-kommunikáció vizsgálatot további módszerekkel egészíthetjük ki. A kikérdezés módszerével közvetlenül a team tagjaitól nyerhetünk információt ismereteikre, véleményükre és attitűdjükre (Nádasi, 2004). A személyes kapcsolatrendszer - mint a formális kapcsolatrendszer befolyásoló tényezője - szociometriai kérdőív segítségével mérhető fel.

\section{KONKLÚZIÓ}

A team kommunikációjának mérését vizsgáló módszer kiválasztásakor figyelembe szükséges vennünk a rehabilitációs team sajátosságait. Az orvosi rehabilitációban a munkaközösség mindig multiprofesszionális szerveződésű, s minden esetben tagja a páciens és annak családja is. Eltérő team modelleket találhatunk, melyek megállapításához az interakciós vizsgálatok segítséget nyújtatnak. A vizsgálati eredményeink értékelésekor e modelleket és a team dinamikájának állomásit is szükséges figyelembe vennünk. Vizsgálatunk célja lehet a kommunikációs folyamat sajátosságainak rögzítése, illetve eredményességének meghatározása. Szükséges e vizsgálati célhoz társítanunk a vizsgálati, interakciós-helyzetet. A gondosan megválasztott mérési helyzet mellett a megfigyelés eszközeinek meg kell felelniük a könynyú és pontos használhatóságnak. Az etikai és mérési nehézségek a vizsgálati helyzettôl függetlenül jelen vannak, az utóbbi enyhítésére a módszerek kombinációja szükséges.

\section{IRODALOM}

Allan, C. M., Campbell, W. N., Guptill, C. A., Stephenson, F. F., \& Campbell, K. E. (2006). A conceptual model for interprofessional education: The International Classification of Functioning Disability and Health (ICF). Journal of Interprofessional Care, 20, 235-245 doi: $\underline{10.1080 / 13561820600718139}$

Allender, S., Scarborough, P., Peto, V., Rayner, M., Leal, J., LuengoFernandez, R., és mtsai. (2008). European cardiovascular disease statistics 2008 edition. European Heart Network.

Bokhour, B. G. (2006). Communication in interdisciplinary team meetings: what are we talking about? Journal of Interprofessional Care, 20(4), 349-363. doi: $\underline{10.1080 / 13561820600727205}$ 
Cans, C. (2000). Surveiilance of cerebral palsy in Europe: a collaboration of cerebral palsy surveys and registers. Developmental Medicinie \& Child Neurology, 42, 816-24. doi: 10.1111/j.1469-8749.2000.tb00695.x

Falus I. (2004). A megfigyelés. In I. Falus I. (szerk.): Bevezetés a pedagógiai kutatás módszereibe. Budapest: Műszaki Könyvkiadó. 99-118.

Fejes, M., Varga, B. és Hollódy, K. (2019). A cerebralis paresis epidemiológiája, költségei és közgazdasági hatásai. Ideggyógyászati Szemle, 72, 3-4. doi: $\underline{10.18071 / \text { isz. } 72.0115}$

Hámornik, B. P. (2013). Team-tudás, interakció és kommunikáció vizsgálataTudásmegosztás az orvosi rehabilitációs teamben. Doktori Disszertáció. ELTE.

Hutchins, E. (1995). Cognition in the Wild. The MIT Press. doi: 10.1098/rsbl.2011.0352

Jesus, T.S., \& Silva, I.L. (2016). Toward an evidence-based patient-provider communication in rehabilitation: linking communication elements to better rehabilitation outcomes. Clinical Rehabilitation, 30, 315-328. doi: $\underline{10.1177 / 0269215515585133}$

King, G., Strachan, D., Tucker, M., Duwyn, B., Desserud, S., \& Shillington, M. (2009). The Application of a Transdisciplinary Model for Early Intervention Services. Infants \& Young, 22, 211-223. doi: 10.1097/IYC.0b013e3181abe1c3
Körner, M. (2010). Interprofessional teamwork in medical rehabilitation: a comparison of multidisciplinary and interdisciplinary team approach. Clinical rehabilitation, 24(8), 745-755. doi: $10.1177 / 0269215510367538$

Kullmann L. (2010). A rehabilitációs orvoslás elmélete. In Vekerdy-Nagy Z. (szerk.): Rehabilitációs orvoslás. Budapest: Medicina. 23-30.

Kullmann L. (2015). A teammunkára felkészítés lehetőségei a gyógypedagógusképzésben. Gyógypedagógiai Szemle, 43(3), 178-192.

Kullmann L., \& Vekerdy Z. (2006). A képzés jelentősége: Szakemberellátottság a rehabilitációban. Kórház, 12(6), 89-93.

Lyon, S., \& Lyon, G. (1980). Team functioning and staff developmnet: A role release approach to providing integrated education services for severely hadicapped students. The Journal of Association for the Severly Handicapped, 5, 250-263. doi: $\underline{10.1177 / 154079698000500304}$

Nádasi M. (2004). A kikérdezés. In Falus I. (szerk.): Bevezetés a pedagógiai kutatásmódszereibe. Műszaki Könyvkiadó, Budapest. 141-159.

Norrefalk, J.R. (2003). How do we define multidisciplinary rehabilitation? Journal of Rehabilitation Medicine, 35(2), 100-101. doi: 10.1080/16501970306118

Oller, D. K., Niyogi, P., Gray, S., Richards, J. A., Gilkerson, J., Xu, D., és mtsai. (2010). Automated vocal 
analysis of naturalistic recordings from children with autism, language delay, and typical development. Proceedings of the National Academy of Sciences of the United States of America, 107(30), 1335413359. doi: $10.1073 /$ pnas.1003882107

Szél, I., Tóth, A., Kozma, G., Vámos, T., Schneider, H. és Bíró, T. (2015). Célegyeztető megbeszélés: Magyarországon újdonságnak számító, tervezett, teljes körű kommunikációs módszer a rehabilitációs program részeként. Rehabiliáció, 25(3), 112.

Szende, A., Oppe, M., \& Devlin, N. (2006). EQ-5D Value Sets: Inventory, Comparative Review and User Guide. Springer .

Tempest, S., \& McIntyre, A. (2006). Using the ICF to clarify team roles and demonstrate clinical reasoning in stroke rehabilitation. Disability and Rehabilitation, 28, 663-667.

Tuckman, B. W. (1965). Developmental Sequence in Small Groups. Psychological Bulletin, 63(6), 384-399. doi: $\underline{10.1080 / 09638280500276992}$

Tuckman, B. W., \& Jensen, M. C. (1977). Stages of small group development revisited. Group and Organization, 2(4), 419-427. doi:

$\underline{10.1177 / 105960117700200404}$

Woodruff, G., \& McGonigel, M. J. (1988). Early Intervention Team Approaches: The Transdisciplinary Model. In Jordan, June, Ed. and Others (Eds.): Early childhood special education: Birth to three. Washington, D.C.: Office of Educational Research and Improvement. Reston, VA: Council for Exceptional Children. 6485. 


\title{
HOGYAN KÉSZÜL EGY JELNYELVI (SZLENG)SZÓTÁR?
}

\author{
Szerző: \\ Bodnár Noémi (Drs) \\ Eötvös Loránd Tudományegyetem
}

Szerző e-mail címe:

bodnarnoemi@gmail.com

\section{Lektorok:}

Katona Krisztina $(\mathrm{PhD})$

Gál Ferenc Egyetem

Mező Ferenc (PhD)

Eszterházy Károly Egyetem

...és további két anonim lektor

\begin{abstract}
Absztrakt
A jelen tanulmány célja a jelnyelvészeti kutatások rövid áttekintése után a jelnyelvi szleng egy lehetséges meghatározásának bemutatása, az eddig elkészült jelnyelvi szótárak áttekintése, valamint a jelnyelvi anyaggyűjtés kérdéseinek áttekintése, végül pedig egy saját kutatás bemutatása
\end{abstract}

Kulcsszavak: jelnyelv, szleng, szótár

Diszciplina: pedagógia

\section{Abstract}

HOW IS A SIGN LANGUAGE (SLANG) DICTIONARY MADE?

The aim of the present study is to present a possible definition of sign language slang after a brief review of sign language research, to review the sign language dictionaries completed so far, and to review the issues of sign language collection, and finally to present one's own research.

Keywords: sign language, slang, dictionary

Discipline: pedagogy

Bodnár Noémi (2020): Hogyan készül egy jelnyelvi (szleng)szótár? OxIPO - interdiszciplináris tudományos folyóirat, 2020/3, 87-96. doi: 10.35405/OXIPO.2020.3.87 
A jelnyelvkutatás viszonylag fiatal tudomány, Amerikában az 1960-as években indult el és William C. Stokoe nevéhez füzhető, ő ismerte fel, hogy a jelnyelv természetes, teljes értékű nyelv. Az 1960ban megjelenő Sign Language Structure: $A n$ Outline of Visual Communication Systems of the American Deaf című munkája világszerte felkeltette a jelnyelv iránti érdeklődést. Hazánkban 1994-ben, a SINOSZ koordinálásával indultak el a jelnyelvi kutatások.

A jelnyelvi szlengkutatásnak még nem alakult ki bőséges szakirodalma, viszont mivel a szleng nyelvi univerzálé (Penttinen; 1984:7; Tender 1997; Kis 2006), feltételezhető, hogy a jelnyelv használói körében is kialakult és él.

Amerikában 2014-ben szerveztek jelnyelvoktatók részére egy továbbképzést, melynek során kifejezetten az amerikai jelnyelvi szlengre koncentráltak

A wsrid.com oldalon található jelnyelvi továbbképzés meghívóban (Net1) olvasható a következő szövegrészlet:

„This workshop will provide participants an opportunity to learn some of the newest and often used ASL slang signs and colloquialisms and their meanings."

Azaz:

„Ez a workshop lehetőséget nyújt a résztvevőknek arra, hogy elsajátítsanak néhány új és népszerű kollokviális és szleng elemet az amerikai jelnyelvből".
Több siket vlogger is utal a jelnyelvi szleng létezésére (Vö.: Net2, Net3). Rövidebb internetes cikkek is szólnak mind a külföldi, mind a magyar jelnyelvi szlengről - például: Sheffield, Duncan és Strasser (2015), Jaxon (s.a.), Iván Viktória (2014) „Így küld el a fenébe egy siket ember”.

A jelnyelvben a szleng fogalmát csak részben lehet a hangzó nyelvekre irányuló nyelvészeti kutatások mentén meghatározni, ezért fontos meghatározni azt, hogy a jelnyelv mely elemei tekinthetők szlengnek. A jelnyelvi szlenget aligha lehet a jelnyelv standard változatához képest meghatározni, hiszen a jelnyelv standardizációja jelenleg is zajlik.

Pavol Odaloš (1999, 42. o.) szerint „A szlengizmusok egyfajta aktualizációs szándék eredményeként jelentkeznek a kommunikációban. A szlengizmusok aktualizációs szerepével szorosan összefügg változatosságuk és nagyfokú expresszivitásuk". Ez az expresszivitás meghatározó volt a jelek gyújtése során. Kis Tamás (1992, 345. o.) katonai szlengszótárban így ír: „szleng az, amit a beszélője annak érez". Ez a meghatározás olyan szempontból hasznos, hogy a nyelvhasználók állnak a középpontjában, így a jelen gyüjtés során is jól alkalmazhatónak bizonyult. „Vannak úgynevezett siketes jelek, amelyek gyakran 2-3-4-5 szót is képesek egy jelben tömöríteni, vagy egy cselekvést egy jelben megjeleníteni” (Iván, 2014). Ezeket másképp jelnyelvi idiómáknak nevezzük. Baranyai András és Vincze Tamás nevéhez kapcsolódik a Beszél a Kéz című, első- 
sorban gyerekeknek szóló ismeretterjesztő könyvsorozat harmadik részeként 2007ben megjelent Vaker címú könyv, mely jelnyelvi idiómák gyűjteménye. A könyv fülszövegében a következők állnak: „A Beszél a Kéz sorozat harmadik részében a fiatalok rengeteg, mostanában használatos kifejezéssel ismerkedhetnek meg és mindezek mellett kézjelüket is elsajátíthatják.”

A „mostanában használatos kifejezés” meghatározás megengedi azt a felvetést, hogy ezek voltaképp szleng elemek. Olyan szempontból is a szlenghez kapcsolhatjuk az idiómákat, hogy nagyon súrítettek, nagyon kifejezőek, mindig nagy érzelmi többletet hordoznak a köznyelvi megfelelőjükhöz képest. A siketes jel elnevezés az idiómák közösségi jellegét hangsúlyozza, a szlengre pedig jellemző, hogy egy adott közösség tagjainak összetartozását erôsíti.
A jelnyelvi idiómákat (bár nem a jelnyelvi szleng részének tekintve) a külföldi kutatások már érintik (például: Hines. 2015) és léteznek jelnyelvi idiómagyűjtemények is. Ezek az idiómagyűjtemények nem mindig hozzáférhetők széles körben (lásd például: Net4). Léteznek olyan cikkek is, amelyek nem illusztrálják vizuálisan a jelelés módját, csak leírják a jelek kivitelezését (Panse, 2012). Létezik megvásárolható Idioms \& Phrases in American Sign Language címú DVD-sorozat is, valamint ingyenesen hozzáférhető online jelnyelvi szótár (Net5), ahol találhatók jelnyelvi idiómák. A magyar jelnyelv idiómáiról eddig még nem készült gyűjtemény.

Mivel a jelnyelv vizuális nyelv, jelnyelvi szótárat alkotni csak ezt a tulajdonságát figyelembe véve lehet (v.ö.: 1. ábra).

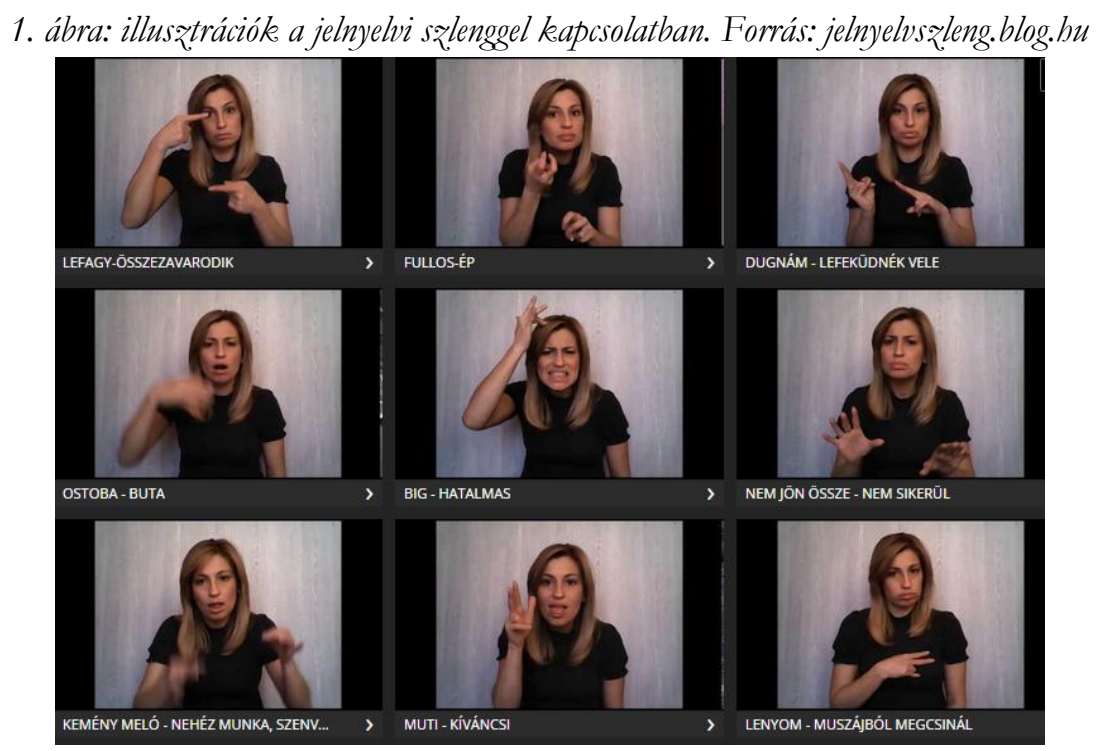


Számos jelnyelvi szótár létezik, néhány példa a teljesség igénye nélkül: az amerikai American Sign Language Dictionary (Sternberg, 1998), a francia La langue des signes sorozat második kötete (Moody, 1986), a görög Systema hellenikon neumaton (Triantaphullides, 1987), az olasz Dizionario bilingue elementare della lingua italiana dei segni (Radutzky, 1992), stb.

Amerikában 2011-ben megjelent egy Dirty Sign Language: Everyday Slang from „What's Up?” to „F*o\# Off!” (Dirty Everyday Slang) címú jelszótár (Van James és Allison, 2011), amely számos jelnyelvi szleng kifejezést gyújtött össze olyan témakörökből, mint például a bulizás, flört, sport, emberi kapcsolatok, szexualitás. Ez a kötet jó kiindulási pont lehet egy hasonló magyar jelnyelvi szlenget leíró kötethez.

A magyarországi kutatók közül Lancz Edina (1999) alkotta meg A magyar jelnyelv szótárát. Ebben a munkában a kézformák adják a rendszerezés alapját. Habár kétségtelenül hatalmas gyüjtőmunka eredménye e szótár, sajnos a munka egyáltalán nem teljes, inkább csak egy rövid kivonat a jelnyelv néhány eleméről. Ez a hiányosság abból adódik, hogy nyomtatott formában nagyon körülményes bemutatni a jelnyelvet, Lancz (1999) - jellemzően a jelnyelvi szótárak szerzőire - fotókkal szemlélteti a jeleket, és valóban ez tűnik a legszerencsésebb eljárásnak ilyen munkák esetében, hiszen a jelnyelvnek nem igazán van egy egységes, kidolgozott, jól mûködő lejegyzési rendszere.
Egy másik lehetséges út a jelnyelvi szótárak létrehozására az online videoszótárak alkotása. Az ilyen jellegű szótáraknak számos előnyük van a nyomtatott változatokkal szemben: könnyen hozzáférhetők, folyamatosan fejleszthetők, bővíthetők, pontosabbak, szemléletesebbek, épp ezért talán eredményesebben használhatók. A legnagyobb videoszótár a Spread the sign nevü (Net6), amely egy rendkívül jól rendszerezett és bőséges nemzetközi jelnyelvi adatbázis.

A hazai gyakorlatban is jelen vannak az online jelnyelvi szótárak, például a Hallatlan Alapítvány jelnyelvi szótára (Net7), vagy a JelEsély jelnyelvi szótár (Net8). A Hallatlan Alapítvány szótára tematikus csoportokba rendezett jeleket tartalmaz, a JelEsély jelnyelvi szótár jelei viszont kereshetők fő kézforma, alkézforma, kivitelezési hely, a jel típusa, mozgás típusa, mozgás iránya, jelnyelvi változat terület szerint, valamint a felvétel típusa szerint. E változatos keresési szempontok nagyon előnyösek egy online szótár esetén, megkönnyítik a jelek közötti tájékozódást. A magyar jelnyelvi szlengszótár is videoszótár formában, online platformon mûködhet igazán eredményesen.

\section{MÓDSZERTAN}

A jelnyelvi szleng gyüjtése több szempontból is eltér a beszélt, vagy írott magyar nyelvi anyag gyűjtésétől. Néhány gyűjtési módszer (kérdőíves vizsgálat, diktafon használata) alapvetően szóba sem 
jöhet, hogyha jelnyelvi elemeket szeretnénk gyújteni, épp ezért az egyetlen rögzítési mód, ami a kutatás során használható, a videofelvételek készítése, ez az eljárás viszont nem problémamentes.

Labov (1972, 209. o.) nevéhez füződik az úgynevezett „megfigyelői paradoxon”. A megfigyelői paradoxon abból adódik, hogy a nyelvhasználók nyelvi megnyilvánulásainak megfigyelésekor „Célunk, hogy megfigyeljük, hogyan beszélnek az emberek akkor, amikor nem figyeljük őket" (Trudgill 1997, 49. o.). Hogyha bekapcsolt videokamerával érkezünk egy beszélgetésre, akkor valószínű, hogy az adatközlők eleinte nem fognak tudni természetesen viselkedni, zavarban lesznek, feszengeni fognak. Fontos minimalizálni ezt a feszültséget, megpróbálni elérni azt, hogy megfeledkezzenek a kameráról, és a lehető legtermészetesebben viselkedjenek.

A megfigyelői paradoxon csökkentésének egyik módja, hogy igyekszünk olyan témákról kérdezni, amely a közösséget érdekli és érinti. A siket közösséget például célszerű lehet a hallássérülésükről kérdezni, arról, hogy hogyan élik meg a mindennapokban, mennyire érzik hátránynak, mi a véleményük az oktatásról, mit gondolnak magáról a jelnyelvről, milyen tapasztalataik vannak a hallókkal, stb.

Viszont az így születő jelnyelvi interjúkból nehéz lehet kiszűrni a szleng elemeket, így fontos lehet valamilyen konkrét módon is rákérdezni arra, hogy mit tekintenek ők maguk szlengnek. Ezzel viszont az az alapvető probléma, hogy a szlenget mint nyelvészeti fogalmat valószínúleg nem ismeri minden siket, ha érzik is, mi az, nem tudnak egyértelmú definíciót adni (nem feltétlenül a siketségük okán). Ha viszont egy kész definíció ismertetése alapján kérünk tőlük szleng elemeket, nem biztos, hogy (a nyelvi nehézségeik miatt) eredményes gyűjtést tudunk végezni. Az lehet a megoldása ennek a problémának, hogyha körültekintően választunk adatközlőket, és minimalizálni tudjuk a kommunikációs nehézségeket.

A fent felvetett problémák minimálisra csökkenthetők. Az egyik megoldás az lehet, hogyha a gyüjtést jelnyelvi tolmácsok segítségével végezzük el. Ők könnyen akadálymentesíthetik a siket-halló kommunikációt, és a jelenlétükben talán nem is olyan lámpalázasak a kamera előtt a siketek. Egy másik megoldás az lehet, ha jelnyelvi tolmácsokkal végezzük a gyűjtést (tehát őket kérjük fel adatközlőnek). Valószínűsíthetően ők sem szoronganak a kamera előtt, és a hangzó magyar nyelvnek is ismerik olyan jól a szerkezetét, hogy könnyen megértenek egy szlengdefiníciót, így egyszerúbben tudnak szleng jeleket mutatni, mint a siketek. Ennek a megoldásnak azonban több hátránya is van: a tolmácsok időbeosztása nagyon feszes, nehéz olyan jeltolmácsokat találni, akik szívesen részt vennének egy ilyen gyűjtésben, ráadásul még nehezebb olyan jeltolmácsot találni, aki anyanyelvi szinten használja a jelnyelvet.

Harmadik lehetőségként készülhet a gyüjtés jelnyelvoktatók segítségével. A jel- 
nyelvoktatók elég magas szinten ismerik a hangzó magyar nyelvet (használniuk kell nap mint nap az oktatás során), és anyanyelvként használják a jelnyelvet is. Szívügyük a jelnyelv, így szívesen segítenek az ilyen jellegű feladatokban, a velük való kommunikáció könnyebb, mint a többi sikettel, így tolmácsra sincsen szükség. Vannak nyelvészeti ismereteik, mert az oktatóképzés során kötelezően hallgatnak jelnyelvészetet, így ezen terület terminológiájában is jártasak, hozzá vannak szokva a kamerához (általában saját óráikra is maguk készítik a videókat). Az anyaggyüjtésben tehát jelnyelvi oktatók segítségét is kérhetjük. Ez viszont felveti azt a problémát, hogy a jelnyelvoktatók a jelnyelvhasználó közösségen belül valamelyest „kibic”-nek számítanak, hiszen kevéssé szabályosan használják a jelnyelvet, mint a csoport belső tagjai (Sándor, 1995).

A jelnyelvi anyaggyűjtés első lépéseként elengedhetetlen a siketkultúra tanulmányozása, a jelnyelv minél magasabb szintű elsajátítása. A gyüjtés elején fontos lehet minél jobban bekerülni a siket közösségbe, minél több sikettel találkozni, beszélgetni. Ezek a beszélgetések tulajdonképpen szociolingvisztikai interjúként is funkcionáltak, habár videofelvétel nem készült róluk, csak jegyzetek. A siketekkel való beszélgetések során kiderült, hogy legtöbben nem ismerik a szleng fogalmát, nem tudnának definíciót adni rá.

Azok, akik ismerik a szleng terminust, és van róla fogalmuk, hogy mit jelent, direkt kérdésekre is tudnak választ adni - például: „Milyen szleng jele(ke)t ismersz a ...ra?” vagy „Van szleng jel a ...-ra? típusú kérdésekre is válaszolhatnak. Ez a gyüjtési módszer rávilágított arra, hogy a hangzó magyar nyelv szlengje és a magyar jelnyelvi szleng részben fedi egymást. A következő témakörök kerültek fókuszba a gyűjtés során: hallók-hallássérültek, iskola, ismerkedés, flört, technika, szórakozás, ételek, érzelmek, sport, öltözködés, külső, szexualitás, vita, emberi kapcsolatok, betegség, testrészek, hobbi, tudatmódosító szerek.

Időnként nehézséget okozott a jelek szleng voltának eldöntése, például a szitokszavak (azaz „szitokjelek”) esetében, de végül - az adatközlők véleményére alapozva - ezek is bekerültek a korpuszba. Az összegyüjtött jelekről lista készült, ez szolgál a szótár alapjául.

Ötven jel összegyűjtése után elkezdődött a jelnyelvi szótár készítése. A jelnyelvi szlengszótár (Net9) szócikkeinek felépítése csak részben illeszkedhet a klasszikus nyomtatott szótárak szócikkeinek felépítéséhez. Mivel a szótár egyrészt jelszlengmagyar kétnyelvű szótár, másrészt egynyelvű jelnyelvi szótár is, a szócikkekben szerepel:

- a szlengjel neve,

- videofelvétel a jelrôl,

- a szlengjel neutrális megfelelőjének neve (amennyiben van),

- videofelvétel a szlengjel neutrális megfelelőjéről,

- a szófaj, 
- a jelentésárnyalat (ahol megállapítható),

- mind a szlengjelet mind annak neutrális megfelelőjét tartalmazó példamondatok.

Lehetnek olyan szócikkek, ahol a szlengjel neutrális megfelelője a jelentésmegadásban segít, lehetnek olyan szócikkek, ahol a neutrális pár csak a kontraszt miatt szerepel, és lehetnek olyan szócikkek is, ahol nem lesz a szlengjelnek neutrális megfelelöje, itt a példamondat segít a jelentésmegadásban.

Mivel a hangzó és a jelnyelvi szleng csak részben fedi egymást, adódhatnak fordítási problémák. Előfordulhat, hogy a szlengjelnek van szleng megfelelője a hangzó nyelvben, viszont előfordulhat, hogy csak körülírással adható meg a jelentése, ilyenkor pedig nehezen érzékeltethető a fordításban a stílusárnyalat. Ebben az esetben példamondatok segíthetnek, így a fordításbeli problémák ellenére is meggyőző lesz az, hogy az adott jel a jelnyelvben szlengnek minősül.

A szótárba jelkapcsolatok is kerülhetnek. A jelnyelvi szótárakra általában jellemző, hogy a szavakat tematikus csoportba rendezve dolgozzák fel. Megjegyzés: a hangzó nyelvi szlenget feldolgozó szótárak közül is létezik olyan, amely tematikus csoportokba rendezi a gyüjtött anyagot (például: Hoffmann, 1996). Ennek az az előnye, hogy egyszerűbben áttekinthetők egy-egy témakör szavai, viszont mindig felveti azt a problémát, hogy bizonyos elemek nem férnek bele egy kate- góriába sem, így általában születik egy „egyéb” kategória. Ezt elkerülendő maga a jelnyelvi szlengszótár a szócikkeket a szleng jelek hangzó magyar nyelvi megfelelőinek alfabetikus sorendjében dolgozza fel.

A jelnyelvi szótárakra általában jellemző, hogy a szavakat tematikus csoportba rendezve dolgozzák fel. Ennek az az előnye, hogy egyszerűbben áttekinthetők egy-egy témakör szavai, viszont mindig felveti azt a problémát, hogy bizonyos elemek nem férnek bele egy kategóriába sem, így általában születik egy „egyéb” kategória. Ezt elkerülendő a jelnyelvi szlengszótár a szócikkeket alfabetikus sorendben dolgozza fel. Mivel minden egyes elem kereshető, a tematikus csoportosítás hiánya nem jelenthet problémát.

\section{ZÁRÓGONDOLATOK}

A hazai jelnyelvi szleng még kevéssé kutatott, korábban nem készült még sem nyomtatott, sem digitális formában gyűjtemény a magyar jelnyelv szleng jeleiről. A jelnyelvi anyaggyűjtés némileg eltér a hangzó nyelvi anyaggyújtéstől: nagyobb szerepet kap például a megfelelő digitális eszközök használata, s az adatközlők körültekintő kiválasztása. A jelnyelvi oktatók segítsége rendkívül hasznos lehet az ilyen jellegű gyűjtések során. A jelnyelvi szótárak készülhetnek nyomtatott, vagy online formában, az online változat számos előnye miatt a magyar jelnyelvi szlengszótár (Net9) is ilyen módon készül. 
A magyar jelnyelv szleng elemeinek további gyűjtése és a szótár folyamatos fejlesztése mellett számos kérdés vizsgálatára nyílhat még lehetőség a jelnyelvi szlenggel kapcsolatban. Például:

1) Egy-egy szlengjel idegen jelnyelvből átvett jövevényjel-e, vagy belső keletkezésû?

2) A jeleknek van-e neutrális megfelelője, vagy sem?

3) A jel esetleges neutrális párjához képest a kollokviális/szleng jel milyen eltérést hordoz?

4) A hét magyar jelnyelvjárás melyikében használják a jeleket?

5) Hol használnak hasonló jelentéstartalommal más jelet?

6) A szlengjel más jelentésben is használatos-e?

Felmerülnek még a kollokviális és szleng jelekkel kapcsolatban egyéb kérdések is, például hogy a siketiskolákban hogyan alakul a jelnyelvi szleng, hogy vannak-e tipikus használói a szlengnek, hogy van-e eltérés a siket családba született és a halló családba született siketek jelnyelvi szlenghasználatában.

\section{IRODALOM}

Baranyai A. és Vincze T. (2007): Vaker. Csimota Könyvkiadó, Budapest.

Berke, J. (2015): Using Name Signs for Personal Names. How do I get one? Letöltés: 2016. április 13. Web: deafness.about.com/od/expressionan dfun/a/signnames.htm
Moody, B. (1986): La langue des signes Tome II Dictionnaire bilingue élémentaire. Paris: Ellipses.

Hines, B. (2015): The Comprehension of Idioms in the Deaf Culture. In: Unconventional Wisdom: University of Montevallo McNair Scholars Research Journal, Volume III. Montevallo 16-26.

Hoffmann O. (1996): Mini-tini szótár. Janus Pannonius Tudományegyetem Továbbképző Központ University Press, Pécs.

Iván V. (2014): Így küld el a fenébe egy siket ember. NLCafé. Letöltés: 2016.04.13. Web: http://www.nlcafe.hu/foto/20 140801/jelnyelv-szleng-siket-fiatalok/

Jaxon, R.: How to Use ASL Slang (American Sign Language Slang) Letöltés: 2016. 12.11. Web: https://snapguide.com/ guides/use-asl-slang-american-signlanguage-slang/

Kis T. (1992): Bakaduma. A mai magyar katonai squleng szótára. Zrínyi Kiadó, Budapest.

Kis T. (2006): Is Slang a Linguistic Universal? [Nyelvi univerzálé-e a szleng?]. Revue d' Études Françaises 11. 125-141. Letölés: 2016.04.6. Web: http://mnytud.arts.klte.hu/szleng/tan ulmanyok/szluniv_eng.htm

Labov, W. (1972): Sociolinguistic patterns. Philadelphia (USA): University of Pennsylvania Press.

Lancz E. (1999): A magyar jelnyelv szótára. Siketek és Nagyothallók Országos Szövetsége, Budapest. 
Net1: Workshop on American Sign Language Slang and Colloquialisms Part 1. Letöltés: 2016.12.06. Web: http://wsrid.com/ event-1790687

Net2: Shannon, Rogan: A Deaf Perspective: ASL Signs and Slang | ft. Ren Putz. Letöltés: 2016.12.11. Web: https://www.youtube.com/watch?v= K2iRwQJh9dk

Net3: Sign Language Slang. Letöltés: 2016. 12. 11. Web: https://www.youtube. $\mathrm{com} / \mathrm{watch} ? \mathrm{v}=\mathrm{mSK}$ snxbTVb0

Net4: SigningSavryv. Letöltés: 2016. 12. 12. Web: https://www.signingsavvy.com/ wordlist/3371/idioms

Net5: American Sign Language Video Dictionaries and Quizzes. Letöltés: 2016.12.12. Web: http://www.aslpro. com/cgi-bin/aslpro/phrases.cgi

Net6: Spread the sign. Letöltés: 2020.09.28. Web: https://www.spreadthesign.com Net7: A Hallatlan Alapitvány jelnyelvi szótára. Letöltés: 2020.09.08. Web: https:// www.hallatlan.hu/c/jelek/

Net8: JelEsély jelnyelvi szótár. Letöltés: 2020.09.28. Web: http://szotar2.jel esely. hu

Net9: Jelnyelvi szlengszótár. Letöltés: 2020.09.28. Web: https://jelnyelv szleng.blog.hu/

Odaloš, P. (1999): Mi a szociolektus és mi a szleng? In: Fenyvesi A., Kis T. és Várnai J. Sz. (szerk.): Mi a szleng? Kossuth Egyetemi Kiadó, Debrecen. 4150.

Panse, S. (2012): How to Sign Popular Idioms. Letöltés: 2016.12.12. Web: http:/ / www.brighthubeducation.com/ studying-a-language/40538-idioms-inamerican-sign-language/

Penttinen, A. (1984): Sotilasslangin sanakirja. Helsinki: Porvoo WSOY.

Radutzky, E. (1992): Dizionario bilingue elementare della lingua italiana dei segni. Bologna: Kappa.

Rizzo, M. (2008): At Home with Marlee Matlin. People, Vol.69. No.16. 99-100.

Sándor K. (1995): Az élőnyelvi vizsgálatok és az iskola: a kisebbségi kétnyelvűség. Regio: Kisebbségtudományi Szemle, 1995 (4). 121-148. o.

Sheffield, M., Duncan, A. \& Strasser, A. (2015): Internet Slang Meets American Sign Language. Letöltés: 2016.12.11. Web: http://www.hopesandfears.com /hopes/now/internet/168477-interne t-american-sign-language

Sternberg, M. L. A. (1998): American Sign Language Dictionary, Third Edition. New York: Harper Collins Publishers.

Stokoe, W. C. (1960): Sign Language Structure: An Outline of Visual Communication Systems of the American Deaf. Journal Of Deaf Studies And Deaf Education, 1960, 10 1, 3-37.

Tender, T. (1997): Az észt szleng és kutatása. In: Kis T. (szerk.): A sqlengkutatás útjai és lehetóségei. Kossuth Egyetemi Kiadó, Debrecen. 91-119.

Triantaphullides, G. (1987): Systema bellenikon neumaton. Thessalonika: Hoi Philoi Ton Kophalalon Thessalonikes 
Trudgill, P. (1997): Bevezetés a nyelv és társadalom tanulmányozásába. JGyTF Kiadó, Szeged.

Tucker, B. P. (2002): A csend hangjai. Bastei Budapest Kiadói Kft., Budapest.

Van James, T. \& Allison, O. (2011): Dirty Sign Language: Everyday Slang from
"What's Up?" to "F*\%\# Off!" (Dirty Everyday Slang). New York: Ulysses Press.

Vasák I. (2005): A világ siket szemmel. Fogyatékosok Esélye Közalapítvány, Budapest. 
OXIPO

MƯHELY, RENDEZVÉNY 


\title{
ROBOTOK, HADVISELÉS, TANULÁS ÉS A VILÁGÜR MEGHÓDÍTÁSA \\ - AVAGY: AZ V. NEMZETKÖZI INTERDISZCIPLINÁRIS KONFERENCIA MÜHELYTITKAI
}

\author{
Szerző: \\ Mező Lilla Dóra \\ Eötvös Loránd Tudományegyetem
}

Szerző e-mail címe:

dori.mezo1@gmail.com

\author{
Lektorok: \\ Szabóné Balogh Ágota (PhD) \\ Gál Ferenc Egyetem \\ Lestyán Erzsébet (PhD) \\ Gál Ferenc Egyetem \\ ...és további két anonim lektor
}

\begin{abstract}
Absztrakt
Mesterséges intelligencia, pszichológiai hadviselés, az emberi információfeldolgozás hatékonyságának növelése és a Földön kívüli emberi élet életkörülményeinek biztosítása - az V. Nemzetközi Interdiszciplináris Konferencia (Debrecen, 20.03.2020-01.05.20) e négy téma köré csoportosult.
\end{abstract}

Kulcsszavak: mesterséges intelligencia, terraformálás, lélektani hadviselés, tanulás, nemzetközi, interdiszciplináris, konferencia

Diszciplinák: interdiszciplináris tudományok

\section{Abstract:}

ROBOTS, WARFARE, LEARNING, AND SPACE CONQUERCE

- THE V. INTERN ATIONAL INTERDISCIPLINARY CONFERENCE

Artificial intelligence, psychological warfare, increasing the efficiency of human information processing and ensuring the living conditions of extraterrestrial human life - the 5th International Interdisciplinary Conference (Debrecen, 15.03.2020-01.05.2020) was grouped around these four themes.

Keywords: artificial intelligence, terraforming, psychological warfare, learning, international, interdisciplinary, conference

Disciplines: interdiscipline sciences

Mező Lilla Dóra (2020): Robotok, hadviselés, tanulás és a világűr meghódítása - avagy: az V. Nemzetközi Interdiszciplináris Konferencia. OxIPO - interdiszciplináris tudományos folyóirat, 2020/3, 99-106. doi: 10.35405/OXIPO.2020.3.99 
Mesterséges intelligencia, lélektani hadviselés, a humán információ feldolgozás hatékonyságának fokozása és a Földön kívüli emberi élet létfeltételeinek biztosítása - az idén e négy téma köré csoportosult az V. Nemzetközi Interdiszciplináris Konferencia. A COVID-19 koronavírusbetegség által okozott világjárvány miatt a rendezvény személes jelenlét nélküli ekonferencia formájában valósult meg. Ennek következményeként az eredetileg 2020.03.20-ára és egy naposra tervezett konferencia másfél hónapon át (2020. 03.15-től 2020.05.01-ig) tartott.

\section{HAZAI ÉS NEMZETKÖZI TUDOMÁNYOS ÖSSZEFOGÁS}

A konferencián 16 ország 274 résztvevőjének 202 előadása fókuszált a fent említett témákra. Az ötödik alkalommal megvalósuló non-profit rendezvény egyik jellegzetessége volt, hogy szervezői köre is tükrözte a tudományos sokszínűséget (1. ábra, lásd még: Mező és Mező, 2020a).

1. ábra: Az V. Nemzetközi Interdiszciplináris Konferencia részutvevői (országonként) és szuervezői köre. Forrás: Kocka Kör

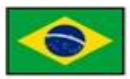

Brazilia

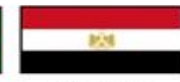

Egyiptom

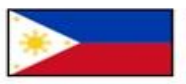

Fülöp-szigetek

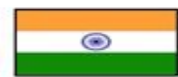

India

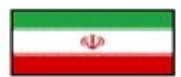

Irán

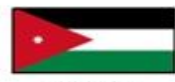

Jordánia

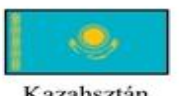

Kazahsztán

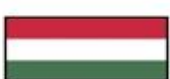

Magyarország

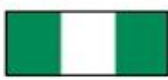

Nigéria

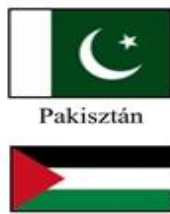

Palesztina

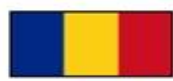

Románia

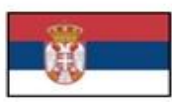

Szerbia

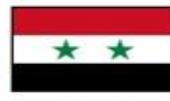

Sziria

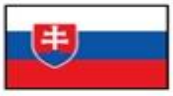

Szlovákia 
A főszervező Kocka Kör Tehetséggondozó Kulturális Egyesület mellett ugyanis a szervezők között éppúgy megtalálhatók akadémiai partnerek - a Magyar Tudományos Akadémia Debreceni Akadémiai Bizottsága, illetve az MTA Miskolci Akadémiai Bizottságának Pszichológiai Szakbizottsága -, mint hazai egyetemek Debreceni Egyetem Tehetséggondozó Programja, Debreceni Református Hittudományi Egyetem, Eszterházy Károly Egyetem - vagy éppen határon túli egyetemek - a szlovákiai Nagyszombati Egyetem, a Romániában múködő Partiumi Keresztény Egyetem, valamint a szerbiai Újvidéki Egyetem Magyar Tannyelvű Tanítóképző Kara -, illetve cégek - a Digital Forensic Pro Csehországból és a hazai $\mathrm{K}+\mathrm{F}$ Stúdió Kft. - és civil szervezetek - a Professzorok az Európai Magyarországért Egyesület. A szervezői kör a konferencia meghirdetésétől a konferencia beszámolók közreadásig terjedően is részt vett a szervezésben, népszerűsítésben (Net1-6).

A konferencia több szempontból is rendhagyó volt - az alábbi fejezetekben áttekintjük sajátosságait.

\section{A VILÁG TALÁN ELSŐ „HIRTE- LEN FELINDULÁSBÓL ELKÖ- VETETT" KONFERENCIASO- ROZATA}

$\mathrm{Az}$ évente egy alkalommal megrendezésre kerülő konferenciasorozat 2016-ban indult - amikor a Kocka Kör elnöke, dr. Mező Ferenc pszichológus, mintegy fél- óra alatt összehívta a kezdőrendezvény nemzetközi szervezői körét. Az apropót egy telefonhívás adta. Egy hallgató kereste fel a Kocka Kört azzal a problémával, hogy nem jut (tudományos karrierje szempontjából fontos) nemzetközi konferencia részvételi lehetőségekhez, mivel azok megfizethetetlenül drágák számára. Az elnök úr a társalgást követően egy félóra múlva már vissza is hívta a hallgatót: örömmel jelezte, hogy az USA, Ausztrália és több európai országból verbuvált szervezői körrel 2016-ban megrendezésre kerülhet az I. Nemzetközi Interdiszciplináris Konferencia. Így jött létre az azóta évente ismétlődő rendezvénysorozat.

A rendezvény sajátosságai már az első alkalommal kialakultak. Fontos volt az interdiszciplináris és a nemzetközi jelleg, és az, hogy elérhető áron - ingyen! - lehessen részt venni a rendezvényen. Ez magával hozta azt is, hogy bevétel és rendelkezésre álló forrás hiányában önkéntes, non-profit tudománysegítő együttmúködésre van szükség a megvalósítás során. A résztvevők által megfogalmazott igény volt továbbá a publikációs lehetőség is. Ezt részben gyüjteményes kötettel, de a 2020-as rendezvénytől kezdve három interdiszciplináris e-folyóirat médiatámogatásával sikerült megvalósítani. E folyóiratok a $\mathrm{K}+\mathrm{F}$ Stúdió $\mathrm{Kft}$. által gondozott „OxIPO”, „Mesterséges Intelligencia” és „Lélektan és Hadviselés” című, nyílt hozzáférésű interdiszciplináris e-folyóiratok.

Már az induláskor kiderült, hogy a konferencia szélesebb igényt elégít ki: az első 
alkalomtól kezdődően oktatók, kutatók is bekapcsolódtak a doktoranduszok és hallgatók mellé előadónak. A Debreceni Egyetem Tehetséggondozó Programja pedig - dr. Varga Zsolt tudományos igazgató és drs. Mándy Zsuzsanna programkoordinátor aktív bekapcsolódásával a kezdetektől fogva támogatta a rendezvénysorozatot.

\section{INTERDISZCIPLINÁRIS SZEMLÉLET}

Egy-egy diszciplina művelői általában saját tudományterületük szakmai folyóirataiban, tudományos rendezvényein szokták közreadni kutatási eredményeiket, nézeteiket. Ez a tudományos közlés hagyományos, elengedhetetlenül fontos, ráadásul praktikus formája. Vitathatatlan, hogy egyazon téma iránt érdeklődő kutatók eszmecseréjét, szakmai kapcsolataik megerősítését esetleg kialakítását az adott területen kutató különböző generációk párbeszédét az unidiszciplináris konferenciák elősegíthetik.

Jelen konferencia azonban az interdiszciplináris érdeklődésű kutatók számára kívánt fórumot biztosítani. A Nemzetközi Interdiszciplináris Konferenciasorozat szakított a hagyományos, egyetlen tudományágon belüli megközelítéssel, annak érdekében, hogy elősegítse a legkülönbözőbb tudományágak képviselői közötti párbeszédet. Így lehetőség nyílt arra, hogy megismerhessék egymás kutatási témáit, eredményeit például a jog- és az orvostudomány, a pedagógia és a pszicholó- gia, az irodalom és a médiatudomány, az informatika és a természettudományok képviselői.

Az interdiszciplináris sokszínűség minden előnye mellett azonban kérdésként merült fel, hogy miként lehet megvalósítani azt, hogy az egymástól eltérő tudományterületek egymástól függetlenül múködő előadói tematikusan mégis kapcsolódjanak egymáshoz. A megoldást a szervezők által megadott központi témák jelentették, amihez a résztvevőknek kapcsolódniuk kellett legalább egy távoli asszociáció erejéig. Így lehetőség nyílt arra, hogy például a szarvasmarha tenyésztésről, a tehetséggondozásról, az irodalomtörténetről, a nemzetközi jogról stb. értekező résztvevők elgondolkozzanak azon és rámutathassanak arra, hogy témájuk hogyan kötődik mondjuk a „Földön kívüli humán életfeltételek biztosítása" témához. Olyan kérdések és válaszok (esetleg új kutatási irányok, együttműködések) merülhetnek így fel, amelyek az adott szúkebb diszciplina esetében nem feltétlenül kerülnének egy kutató figyelmének középpontjába.

Néhány példa:

Milyen nehézségekbe ütközhet egy Hold- vagy Marsbéli állattenyésztő farm a jövőben?

Hogyan lehet terraformálás-témára komplex tantárgyi megközelítésű tehetséggondozó programot tervezni?

A tudományos-fantasztikus irodalomban milyen megoldások találhatók 
űrvárosok, -kolóniák létrehozásával kapcsolatban?

Milyen nemzetközi és űrjogi vonatkozásai lehetnek más égitesteken történő nemzeti vagy nemzetközi jellegü települések, társadalmak létrehozásának?

A tudományági sokszínűség közötti öszszekötő kapocsként (a konferenciasorozat előző négy alkalmához hasonlóan) az idén is azt kérték a szervezők az előadóktól, hogy legalább egy gondolat erejéig villantsák fel, hogyan kapcsolódik saját előadásuk a szervezők által megadott átfogó témakörökhöz. Az idei témakörök: „Mesterséges intelligencia”, „Lélektan és hadviselés”, „Humán élet a Földön kívül”, illetve a humán információfeldolgozás hatékonyságának fokozását célzó kutatásokat összefogó „OxIPO” elv.

\section{MESTERSÉGES \\ INTELLIGENCIA}

A konferencia résztvevői rámutattak például a mesterséges intelligencia (MI) szereplehetőségére az orvosi diagnosztikában, terápiában, képzésben és kutatásban (legyen szó akár rákkutatásról, Alzheimer-kórról vagy sportsérülésekről) vagy éppen a fizika terén a részecskekutatásban, az anyagtudományban, a matematikában, hálózatkutatásban. A reflexiók választ kerestek olyan kérdésekre, mint: Hogyan segítheti az MI a jelnyelvi tolmá- csolást, a tanulásban akadályozott gyermekek és/vagy a tehetségesek támogatását? Miként segíthetik robotok a precíziós mezőgazdaságot? Ki vagy MI vezeti a jövő autóit, s ha baleset történik, akkor kié a jogi felelősség? Rámutattak, hogy a hulladékgazdálkodástól, az e-sporton és sportpszichológián át a szociális szövetkezetek irányításáig vagy éppen Luxemburgi Zsigmond huszita hadjáratainak kutatásáig számos területen lehet hatékony eszköz a mesterséges intelligencia. Felmerült azonban az is, hogy az emóciók jelentik az MI korlátait: a szorongást vagy az örömöt éppúgy csak imitálni tudják a napjainkban ismert MI-k, mint az impresszionalista művész alkotóvágyát. Részleteket lásd: Mező és Mező (2020b) tanulmányában.

\section{LÉLEKTAN ÉS HADVISELÉS}

$\mathrm{E}$ témakört tekintve is sokféle elgondolkodtató felvetés fogalmazódott meg. Néhány szemelvény ezek közül: felmerült, hogy a time-lapse videomikroszkópos eljárás (az a technológia, amivel többek között a sebbe került szén nanocsövek aggregációjának hatása vizsgálható a szem szaruhártyájának regenerációja során, s amit citotoxikológiai vizsgálatokhoz is használnak) egyben alkalmas hadmozdulatok megfigyelésére, nyomon követésére is. Vagy: a száradásos repedezettség vizsgálatával kapcsolatos eredmények hozzájárulhatnak a hadiipar által felhasználható mechanikailag ellenálló anyagok fejlesztéséhez. Az erényelméletekkel, ítélkezés- 
elmélettel foglalkozó kutatás a parancsteljesítés, megtagadás témaköréhez kapcsolódhat (mentesíti-e a parancs a katonát a tetteivel járó erkölcsi felelősség alól?). A szorongáskutatás a katonákat (továbbá: tűzoltókat, rendőröket stb.) érő distressz megelőzéséhez, kezeléséhez járulhat hozzá. A lélektan és hadviselés legközvetlenebb asszociációja: a lélektani hadviselés, amely erősokszorozó hatású nem kinetikus, nem halálos fegyvernek tekinthető. A kognitív képességek pszichológiai kutatásának hadtudományi korre-látuma: az első intelligenciatesztek katonai alkalmazásra készültek. Az e-sport a kiképzésben is felhasználható. A lélektani hadviselés közvéleményt, -hangulatot formáló eszközei afrikai nők és férfiak családtervezéssel (korai gyermekvállalás elkerülése, biztonságos szex, nők jogai stb. kérdésekkel) kapcsolatos attitűdjeink formálásában proszociális céllal is alkalmazhatók. Zrínyi Miklós „Szigeti veszedelem” című műve kapcsán pedig felmerült az irodalmi és történelmi szövegek és a honvédelmi alapismeretek oktatása közötti kapcsolat lehetősége. Részleteket lásd: Mező Katalin és Mező Péter Dániel (2020) írásában.

\section{HUMÁN ÉLET}

\section{A FÖLDÖN KÍVÜL}

A legfuturisztikusabbnak tűnő témával kapcsolatban is születtek figyelemre méltó asszociációk a konferencián: az orvostudomány mûvelői körében az űrhajósok fizikai alkalmassága, a földön kívüli környezet egészségkárosító hatásai. A növényélettani folyamatok megismerése és befolyásolása segíthet egy űrhajóhoz hasonló zárt rendszerben a humán életfeltételek legalább részben történő megteremtésében. A növények életfolyamatainak akár kismértékű stresszelése is hasznos anyagok termelését idézheti elő, ami nem földi környezetben is hozzájárulhat az emberi egészség megőrzéséhez és a táplálkozáshoz. Jogi vonatkozás, hogy az ûr „betelepítése emberekkel” a már most is létező űrjogban jelentôs módosításokat fog eredményezni. Ürbázisok, -kolóniák létrehozása máskülönben diákoknak szóló tehetséggondozó programok témája is lehet. Pedagógiai, pszichológiai jellegű észrevétel például, hogy szorongás éppúgy jelentkezhet az űrben, mint a Földön (sőt!), illetve a kognitív képességek fejlesztése, a tantárgypedagógia, a tanulók motiválása a holdbéli pedagógusoknak is álmatlan éjszakákat fog okozni (bár ők rosszabbul járnak földi kollégáiknál, mivel kb. két hetesek a holdbéli éjszakák). A Földön kívüli környezet nem fogja kímélni a jövő űrjárműtervezőit sem, ahogy az űrhulladék kezelése is gondot fog jelenteni. Az irodalom oldaláról felmerült, hogy az írók alkotó fantáziájának termékei, akár az űrtechnológia realitásában önthetnek formát, illetve, hogy a diákok által nem feltétlenül kedvelt klasszikus vagy kortárs művek, miként ölthetnek új köntöst (űrruhát?). A gyógypedagógia terén a fogyatékos embertársaink közösségbe történő 
beilleszkedése, integrációja kapcsán merült fel a hosszú ûrutazásról hazatérő jövőbeli űrhajósok társadalomba történő beilleszkedésének problémája.

\section{OxIPO}

Az OxIPO-pojekt célja a humán információ feldolgozás hatékonyságának fokozása. Az OxIPO egy mozaikszó, aminek betűi az infomrációfeldolgozás fő komponenseire utalnak, ezek: input (információbemenet), proces (inforrációfeldolgozás), output (kimenet), organizáció (az információfeldolgozó folyamat spontán vagy tudatos szerveződése/szervezése). E séma alkalmazható például a tanulás neurológiai, kognitív képességbeli, tanulás módszertani (2. ábra), oktatástechnológiai, személyiségfejlődésbeli, neveléstörténeti stb. elemzésekor, a diagnosztika/terápia tervezésekor, valamint a tudományos kutatások széles körében is.

2. ábra: Tanulási stratégiák az OxIPOmodell alapján. Forrás: Mezọ F.

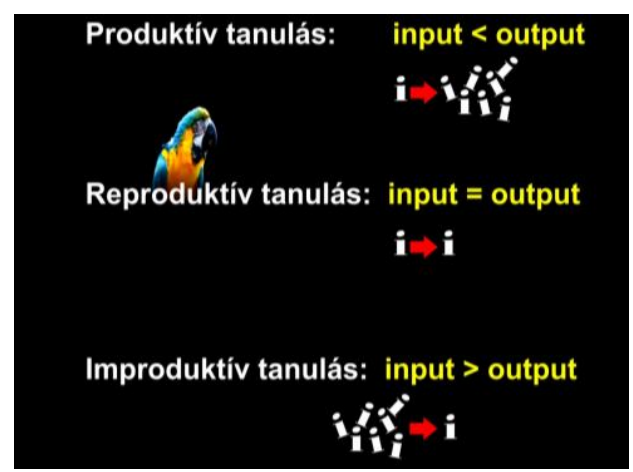

\section{ZÁRÓGONDOLAT}

Mindent egybevetve az V. Nemzetközi Interdiszciplináris Konferencia megvalósította a tervezett feladatait: izgalmas, sokszínű fórumot biztosított résztvevői számára.

Noha személyes jelenléttel megvalósuló konferenciát a COVID-19 vírus-betegség kapcsán kialakult helyzet miatt nem volt lehetséges megszervezni, a világháló mégis lehetőséget nyújtott a tudományos eszmecserére, a különböző diszciplinák képviselői közötti párbeszédre.

A konferencia lehetôséget adott a Nemzeti Tehetség Program támogatásával megvalósuló NTP-PKTF-19-0002 és NTP-NEER-19-0016 projektekben résztvevô fiatalok konferencia tapasztalatainak bővítésében is. A konferencia révén a résztvevő fiatal kutatók (és tulajdonképpen a tapasztalt, senior kutatók is) teljesítményre ösztönző dúsító, gazdagító programban vehettek részt, aminek eredményeként eggyel nőhetett a nemzetközi konferencia szerepléseik száma (több résztvevőnek e rendezvény jelentette az első ilyen jellegű tapasztalatot!), illetve lehetőséget kaptak publikációik megjelentetésére is.

A VI. Nemzetközi Interdiszciplináris Konferencia megrendezését 2021. márciusára tervezi a Kocka Kör Tehetséggondozó Kulturális Egyesület. A rendezvényről 2021. januárjától a Kocka Kör www. kockakor.hu, illetve a $\mathrm{K}+\mathrm{F}$ Stúdió www.kpluszf.com oldalain lesz található bővebb információ. 
Végül a Nemzetközi Interdiszciplináris Konferencia-sorozat egy lényeges sajátosságát is érdemes kiemelni: az életkori és a tudomány fokozatbeli nyitottságot. Ez lehetőséget ad a fiatal kutatóknak olyan szakmai kapcsolatok kialakítására, amelyek hosszú távon meghatározhatják pályafutásukat, kutatási hatékonységukat Másrészt a tapasztalt kutatóknak lehetősége nyílik fiatal tehetségek megismerésére, s mentorálására.

\section{IRODALOM}

Mező Ferenc és Mező Katalin (2020a): V. Nemzetközi Interdiszciplináris Konferencia (Beszámoló). OxIPO - interdisz̨iplináris tudományos folyóirat, 2020/1, 59-70. doi: 10.35405/OXIPO.2020. 1.59

Mező Ferenc és Mező Katalin (2020b): Interdiszciplináris asszociációk vizsgálata a mesterséges intelligenciával kapcsolatban. Mesterséges intelligencia - interdiszciplináris folyoirat, II. évf. 2020/1. szám. 9-31. doi: 10.35406/MI.2020. 1.9

Mező Katalin és Mező Péter Dániel (2020): Az V. Nemzetközi Interdiszciplináris Konferencia a hadviselést, lélektani hadviselést is érintette. Lélektan és hadviselés - interdiszciplináris folyoirat, II. évf. 2020/1. szám. 111-112.

Net1: A Kocka Kör Tehetséggondozó Kulturális Egyesület közleménye (az Országos Sajtószolgálat (OS) felé leadott, s az OS által 2020.03.14-én közzétett hír). Letöltés: 2020.09.28. Web: http://os.mti.hu/hirek/ 150824/a_kocka_kor_tehetseggondozo_k ulturalis_egyesulet_kozlemenye

Net2: E-CONFERENCE! V. International Interdisciplinary Conference (a Magyar Tudományos Akadémia Debreceni Területi Bizottsága honlapján 2020.03.21.-én közzétett hír). Letöltés: 2020.09.28. Web: https://tab.mta.hu/debreceni-teruleti-

bizottsag/eseme nyek/e-conference-vinternational-interdisciplinary-conference

Net3: Az Eszterházy Károly Egyetem oktatói és doktoranduszai is szerepeltek az $V$. Nemzetközi Interdiszciplináris Konferencián (az Eszterházy Károly Egyetem honlapján 2020.03.23.-án közzétett hír). Letöltés: 2020.09.28. Web: https://unieszterhazy.hu/hu/tktk/pk/hirek-1008/c/ v-nemzetkozi-interdiszciplinaris-konferen cia-8477

Net4: Pozvánka na V. Medzinárodnú interdisciplinárnu konferenciu $\mathrm{v}$ Debrecíne (a Trnavská Univerzita v Trnave Pedagogická Fakulta honlapján 2020.03.26.-án közzétett hír). Letöltés: 2020.09.28. Web: http://pdf.truni.sk/ aktuality?2020-03-25-viic

Net5: V. Nemzetközi Interdiszciplináris Konferencia (a Debreceni Református Hittudományi Egyetem honlapján 2020.03.26.án közzétett hír. Letöltés: 2020.09.28. Web: https://www.drhe.hu/hu/v-nem zetkozi-interdiszciplina ris-konferencia

Net6: V. Nemzetközi Interdiszciplináris Konferencia (a Partiumi Keresztény Egyetem honlapján 2020.04.08.-án közzétett hír. Letölés: 2020.09.28. Web: https://htt. partium.ro/hu/hirek/v-nemzetkozi-inter diszciplinaris-konferencia 
OXIPO

RECENZIÓ 
OXIPO 


\section{RECENZIÓ A \\ „GYERMEKEK, TANÁROK, ISKOLÁK - EGYKORON ÉS MA. TANULMÁNYOK A 90 ÉVES MÉSZÁROS ISTVÁN TISZTELETÉRE” CÍMÜ KÖNYVRŐL}

A recenzió szerzője:

Almási Brigitta (Drs)

Eszterházy Károly Egyetem

Szerző e-mail címe:

brigitta.almasi1989@gmail.com
Lektor:

Katona Krisztina $(\mathrm{PhD})$

Gál Ferenc Egyetem

Jaskóné Gácsi Mária (PhD)

Miskolci Egyetem

...és további két anonim lektor

Almási Brigitta (2020): Recenzió a „Gyermekek, tanárok, iskolák - egykoron és ma. Tanulmányok a 90 éves Mészáros István tiszteletére" című könyvről. OxIPO - interdiszciplináris tudományos folyóirat, 2020/3, 109-113. doi: 10.35405/OXIPO.2020.3.109

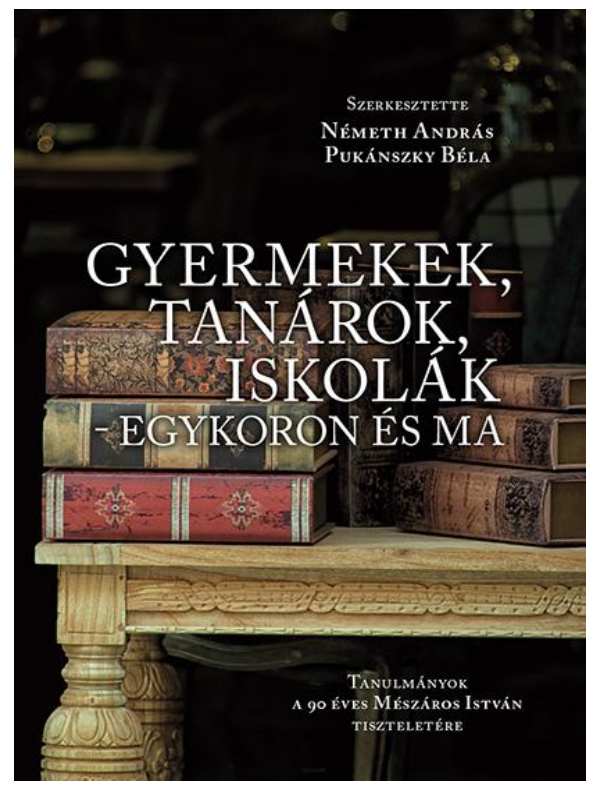

A recenzió alapjául szolgáló mü:

Németh András és Pukánszky Béla (szerk.) (2017): Gyermekek, tanárok, iskolák - egykoron és ma. Tanulmányok a 90 éves Mészáros Istuán tiszteletére. ELTE Pedagógiai és Pszichológiai Kar, Budapest. ISBN 978-963-284-855-6

Kulcsszavak: neveléstörténet, iskola Diszciplína: pedagógia

Bibliography of the subject of this recension:

Németh, András \& Pukánszky, Béla (eds.) (2017): Children, teachers, schools a long time ago and now. Studies in honor of 90 years old István Mészáros. Budapest: ELTE Pedagógiai és Pszichológiai Kar. ISBN 978-963-284-855-6

Keywords: history of education, school Disciplines: pedagogy 
A Gyermekek, Tanárok, Iskolák Egykoron és $M a$ címú tanulmánykötet Németh András és Pukánszky Béla szerkesztésében jelent meg 2017-ben. A kötetben a neveléstudomány olyan jeles kutatóinak és professzorainak tanulmányait olvashatjuk, mint Garai Imre, Golnhofer Erzsébet, Szabolcs Éva, Hegedűs Judit, Kéri Katalin, Mikonya György, Nagy Péter Tibor, Németh András, Nóbik Attila és Pehő Villő.

Garai Imre Teleki Pál, a báró Eötvös József Collegium curátora címú munkájában rávilágít a Collegium szerepére a magyar középiskolai tanári szakma kialakulásában a 1920. század derekán, amely a dulaizmus tudós tanárképzésére épült. A tanulmány részletesen bemutatja Teleki Pál Collegium Curátori tisztségére történő kinevezésének körülményeit, ahol az első világháborút követő országos szinten így a Collegiumban is jelentkező nehézségekkel kellett szembenéznie. A tanulmány művelődéstörténeti szempontból is fontos adalékul szolgál. Garai Imre tanulmányában végig követhetjük a Collegium Teleki Pál törekvését a Cullegium autonómiájáért.

Golnhofer Erzséber és Szabolcs Éva $A$ hagyományok megszakitása, átértelmezése a pedagógiai tankönyvekben az ötvenes évek elsö felében címú munkájukban részletesen olvashatunk a pluralizmus a második világháború utáni időszakban a pedagógia területén való pluralizmus felszámolásáról. A tanulmányban körvonalazódik a szovjet pedagógia hazai megjelenésének aspektusai, majd pedig eljutunk a szovjet pedagó- gia kizárólagosságához. Itt olvashatunk a hazai neveléstudomány átalakulásának folyamatáról, amelyet szovjet mintára alakították át.

A könyvben széles körűen és különböző történelmi korokból emelkednek ki a neveléstudomány, neveléstörténet egyes vonatkozásai. Hegedűs Judit Nők az iskolák élén a 19. sqáạadi Magyarorsqágon címú tanulmányában eme korszak első iskolaigazgatónőinek szerepköreibe vezeti be az olvasót. A téma vezető fonala a női emancipációs mozgalmak hajtóereje, hiszen e mozgalmakban kitüntetett szerepük volt. A tanulmány széleskörūen tárja fel az igazgatónők feladatait, nem pusztán a klasszikus értelemben vett vezetői egyéniséget értjük, hanem sokkal összetettebb, egyfajta írói, publicisztikai szerepköreiket is feltárja a tanulmány. A tanulmáni további részében az igazgatónők közéleti szerepeiről olvashatunk, amelyben a szerző rámutat arra, hogy milyen presztízzsel bírt és a társadalmi ranglétrán milyen helyet foglaltak el e tevékenységet képviselő nők a 19. század végén.

Kéri Katalin Egy páratlan gyerekkortörténeti forrás a reneszánsz. korból: Vives latin nyelvkönyve címú írásában mutatja be az 1492ben, Valenciában született Juan Luis Vives-t és a címben is említett latin nyelvkönyvét. Vives műve a 16. század elején élő gyermekek mindennapjaiba, kérdésköreibe is bepillantást nyújtó dialógusokból áll. Módszertanát tekintve korát meghaladónak tekinthető szerzőről van szó személyében, aki például előtérbe helyezte 
beszédcentrikusságot és túllépett azon a korabeli nyelvtanítási állásponton, miszerint a nyelvtanulás legüdvözítőbb módja korábbi szerzők nyelvi fordulatainak recitálása, utánzása. E latin nyelvkönyv kuriózuma az is, hogy noha 1539-es első megjelenése óta több száz későbbi kiadása ismert és világszerte használatba került, azonban magyar nyelvű fordítása a mai napig nem létezik. A mű időtálló vonatkozásait jól tükrözi Kéri Katalin (idézett mű 49. oldalán) tett megjegyzése is: „A dialógusok szövegei szerint a gyerekek többsége Vives idejében is hasonlóképpen vélekedett az iskoláról, mint manapság: aki már bent volt, kifelé igyekezett, a kicsik képzeletében viszont ez a hely maga volt a mennyország, a káprázatos csodák birodalma...”.

Mikonya György Szempontok az egyetemi nációk kutatásához címú írásában először is a nációk fogalomkörével ismerkedhetünk meg, amelyek egyetemként mást jelentést hordoznak magukban. A tanulmány lépésről lépésre vezeti be az olvasót a nációk szerveződésébe, majd pedig kezdeti törekvéseikről kaphatunk képet. A szerző az egyes európai egyetemek és a nációk kapcsolatának rendszerét mutatja be. Így a párizsi, magyar vonatkozásban a pécsi, bolognai egyetem példáját mutatja be az egyetemi nációk kutatásával kapcsolatban. A tanulmány végigvezeti az olvasót a prágai egyetemen történt nációk okozta incidensen, majd a tanulmány befejező részében a bécsi egyetem példáján jeleníti meg a szerző a nációk megszűnésére.
Nagy Péter Tibor Magyar Állami Oktatáspolitika - a középkorban címú tanulmányában a szerző álláspontja szerint kissé rendhagyóan hangozhat az oktatáspolitika szakkifejezés ebben a kontextusban. Nagy Péter Tibor munkájában az oktatáspolitikát az állam és az egyház viszonyának megvizsgálásával vezeti fel. Ezt követően az állam oktatáspolitikai eszközeire helyeződik a hangsúly és a kolostori és káptalani iskolák állammal való kapcsolatrendszerébe nyerhetünk betekintést. A tanulmányban az államhoz való viszonyulást több szempont mentén vizsgálja a szerző: újabb módszerek alkalmazása az oktatásban, állam és értelmiség kapcsolata.

Németh András Az életreform-kommunák és a reformpedagógiai közösségi nevelés elveinek forrásai és 19. századi elözményei címû munkájában az életreform terminus magyarázatával kezdődik, amely a 19. század azon mozgalmainak összefoglaló definiálására szolgál, amelyek elsősorban NyugatEurópában és Amerikában a modernizációkritikai mozgalmak összefoglalójaként szerepel. A tanulmányban a szerző a kommunamozgalom történeti gyökereitől vezeti az olvasót egészen az ókor, középkor idejétől a romantika életérzéséig. Ezt követően a 19. századi előzményekről olvashatunk, ahol az ipari forradalom következményeinek hatásait mutatja be. A tanulmány az összegzésben rámutat a 20. század kezdetén kibontakozó életreform kibontakozó kommunáira.

A dualizmus kori tanítóképzős neveléstörténeti tankönyveinek kialakulásáról, 
forrásairól írt tanulmányt Nóbik Attila Tanitóképzós neveléstörténeti tankönyveink a dualizmus korában címmel. A szerző rávilágít arra a területre, miszerint a neveléstörténeti tankönyveknek kiemelkedő szerepük van a népoktatási rendszer bemutatásában és a pedagógiai klasszikusok megismertetésében.

A tanulmánykötetet érdemes átlapozni azoknak a kutatóknak is, akik a zenei nevelés történetével foglalkoznak munkájuk során. Pethő Villő Kodály zenei nevelési koncepciójának értelmezési lehetôségei című munkájában. A szerző munkájában részletesen kitér a koncepció pedagógiai sajtóban történő megjelenések fontosságára, valamint arra az aspektusra, hogy a zenei nevelés miként jelenik meg a különféle pedagógiai koncepciókban és iskolakísérletekben. Itt kulcskérdésként szerepel a zenei nevelés szerepe. A tanulmányban a reformpedagógiai kiemelkedő alakjainak munkáját veti össze a szerző Kodály Zoltán zenei nevelési koncepciójával.

A 19. században megjelenő egészségnevelésre vonatkozó ismereteket öleli fel Pukánszky Béla $A$ testi-fiæikai nevelésre, illetve az egészségnevelésre vonatkozó ismeretek megjelenése és kanonizálódása a 19. század elsö évtizedeinek magyar neveléstani kézikönyvekben címmel megjelent tanulmányában. A téma megközelítését Pukánszky Béla a 18-19. századi Magyarországon megjelent neveléstanok és gyakorlati pedagógiai kézikönyvek szerzőivel vezeti fel, mint például Szilasy János, Perlaki Dávid, Tóth Pápai Mihály, Zákány József. A szerző ismerteti tanulmányában a testi nevelés megjelenésének lépéseit a pedagógiában.

Időben előrébb viszi az olvasót Rébay Magdolna Az általános iskola megszervezéséröl szóló rendelet hatása a budapesti református iskolákra című tanulmánya. A szerző tanulmányában kitér a Dunamelléki református egyházkerülethez tartozó iskolák történetére. A tanulmány irányt ad az iskolák átszervezésének felekezeti viszonyokban is megjelenő motívumaihoz. A tanulmány azon része, amely a budapesti református általános iskolák 1945-1948 közötti történetét tárja fel, részletes leírást tartalmaz az iskolaalapítás körülményeiről, és a tanulók létszámainak alakulásával kapcsolatban a források tükrében.

A tanulmánykötetben Sáska Géza Embernek lenni sötét időkeben című munkája rávilágít a marxizmus és leninizmus eszméjével átszőtt szocialista neveléstudomány egyes vonatkozásaira. A szerző a munkájában ismerteti a magyar neveléstudomány pártszerű tudománnyá alakulását. Sáska Géza írásában rámutat arra a lényeges pontra is, miszerint a politika a marxizmus és leninizmus jegyében miként szólt bele a tudományba, majd pedig ennek az ideológiának hanyatlását láthatjuk.

Ugrai János Felbiger és az, ausztriai tevékenysége címmel megjelent tanulmányában megismerhetjük az osztrák népoktatás döntően Felbigerhez köthető fordulatát a 18. század derekán. Ausztriában a népoktatásban bekövetkező változások Felbiger 1774-es meghívásának eredménye lesz. A szerző a tanulmányában részletesen átte- 
kinti a kisiskolák sorsának alakulását és kitér a jozefinizmus évtizedeiben működő elemi iskolázás alakulásra, valamint a lányok nevelésének kérdéseire is.

A tanulmánykötetet Vincze Beatrix $A$ kertmotivum Németh Lásqló pedagógiai és életreform/koncepciójában című tanulmánya zárja. Németh László széles látókörű személyiség volt, noha nem nevezhetjük reformpedagógusnak, mégis sokat tett a Horthy- rendszerben a kultúra továbbadásáért. Vincze Beatrix tanulmányában megismerhetjük Németh László reformpedagógiai koncepcióját, és az életreform kertmotívum egymáshoz való összekapcsolódását. A tanulmány irányt ad a magyar viszonyokra nézve is, ugyanis Németh László pedagógiai reformjával egyúttal a magyarság életreformját is megalkotta. 